\author{
UNIVERSIDADE DE SÃO PAULO \\ FACULDADE DE CIÊNCIAS FARMACÊUTICAS \\ Programa de Pós-Graduação em Ciência dos Alimentos \\ Área de Bromatologia
}

\title{
Análise proteômica de variedades convencionais e geneticamente modificadas de soja (Glycine max) visando proteínas bioativas
}

Sinara Backes

Dissertação para obtenção do grau de MESTRE

Orientador:

Prof. Dr. Flavio Finardi Filho 
Sinara Backes

Análise proteômica de variedades convencionais e geneticamente modificadas de soja (Glycine max) visando proteínas bioativas

Comissão Julgadora

da

Dissertação para obtenção do grau de Mestre

Prof. Dr. Flavio Finardi Filho

orientador/presidente

$1^{\circ}$. examinador

$2^{\circ}$. examinador

São Paulo, de 


\section{AGRADECIMENTOS}

Primeiramente agradeço ao meu orientador Dr. Flavio Finardi Filho, pela oportunidade, presteza e incentivos ao meu trabalho e a minha formação.

A base... meus pais, pela vida, pelas oportunidades de crescimento que me são dados desde 1984 e pelos ensinamentos para a constituição do meu de caráter e que servem de conduta para minha vida.

Agradeço a minha molécula preferida, minha irmã Natália, que me acompanhou nesses quase três anos com bate papos confortadores, animadores, "puxadores" de orelha, contando as notícias em primeira-mão da família e amigos, ajudando a mascarar a distância.

Às colegas de laboratório Giovana, Valdinéia, Beatriz, Natália e Cintia pelas trocas de conhecimento e ajudas mútuas, tanto nas questões práticas, quanto afetuosas, foram essenciais para o convívio e o desenvolvimento do meu trabalho na USP.

À Tatiana e Helena, que além de colegas de trabalho, ótimas amigas pra dividir resultados, alegrias, problemas, caronas (rsrsrs) e inúmeros cafezinhos. A querida Joana, pela prestatividade e alegria contagiante que ajudou a tornar várias situações mais agradáveis.

Ai as paranaenses... Mayara, Roberta, Bianca, Heloísa, as quase paranaenses Fran e Natália, agradeço imensamente pelo companheirismo, as risadas, partidas de uno, cervejinhas, confidências, enfim, a amizade verdadeira. Sei que além de um título, São Paulo me proporcionou amigos que levarei para a vida.

Ao João Ítalo, que além de um estimado amigo teve participação neste trabalho com seus conhecimentos estatísticos. Muito obrigada, te devo uma!!

Aos amigos que ficaram em Floripa e sempre me apoiaram. Em especial a minha grande amiga Nayla, que através de vários "infinitys" me escutou sempre que algo saiu do controle, ou mesmo quando não saía, ligávamos e falávamos por horas para combinar o próximo reencontro em Floripa ou em Sampa.

À todos que acreditaram e contribuíram para a realização deste trabalho.

Ao Departamento de Alimentos e Nutrição Experimental FCF/USP pela oportunidade de realização deste trabalho.

Ao CNPq pela concessão da bolsa de estudos.

À Embrapa - Soja, pelo fornecimento da matéria-prima utilizada neste trabalho.

Ao Laboratório de Espectrometria de Massas do Laboratório Nacional de Biociências, CNPEM - ABTLuS, Campinas - SP, pelo suporte nas análises de espectrometria de massas. 


\section{RESUMO}

\section{Análise proteômica de variedades convencionais e geneticamente modificadas de soja (Glycine max) visando proteínas bioativas}

A soja tolerante ao herbicida glifosato é o vegetal geneticamente modificado mais cultivado. Entretanto, questões sobre a biossegurança dos alimentos GM são ainda levantadas, como as incertezas sobre a expressão das novas proteínas, mutações indesejadas, alterações de perfis nutricionais e aparecimento de compostos tóxicos. Apesar dos comprovados efeitos benéficos à saúde, a soja apresenta naturalmente, entre suas proteínas, fatores antinutricionais, que podem: provocar efeitos fisiológicos adversos; diminuir a biodisponibilidade de nutrientes; e induzir reações de hipersensibilidade. Paralelamente, a soja possui sabor e aroma desagradáveis por ação de enzimas lipoxigenases. Os fatores antinutricionais estão relacionados às aglutininas (lectinas) e aos inibidores de proteases (inibidor de tripsina, tipo Kunitz, e inibidor de tripsina e quimotripsina, tipo Bowman-Brik), enquanto as globulinas da soja respondem pelas reações de hipersensibilidade. Objetivou-se neste trabalho fazer a comparação dos mapas protéicos de soja GM, suas isolinhas convencionais e sojas orgânicas visando a detecção de alterações nos perfis protéicos destes diferentes tipos de cultivo, e também a análise da expressão dos fatores antinutricionais, como os inibidores de proteases e aglutininas, considerando a extensão das variações naturais existentes nas amostras. Para tanto, foram comparadas seis amostras de sementes de variedades comerciais de soja cultivadas em paralelo, sob as mesmas condições ambientais e de solo, compostas por três isolinhas genitoras e suas três correspondentes GMs e duas amostras orgânicas, sendo que uma delas é comercial e a outra ainda esta em campos de pesquisa, fornecidas pela Embrapa Soja. Foram analisados extratos protéicos de todas as amostras, após extração com ácido tricloroacético (TCA) e acetona, através de eletroforese unidimensional (1D) e bidimensional (2D). Nestas foi empregado gradiente de $\mathrm{pH}$ de 3-10 e as imagens avaliadas pelo software ImageMaster 2D Platinum. Diversos spots selecionados foram identificados por espectrometria de massas. Nas imagens dos géis 2D, foi possível identificar e quantificar os spots correspondentes às proteínas isoladas e não houve diferença estatística ao nível de significância de $5 \%$ entre os diferentes tipos de cultivo. Na verificação da sobreposição dos géis, obtivemos porcentagens de matchings superiores a $70 \%$ entre as amostras GMs e não GMs. As amostras orgânicas apresentaram \% matchings menores que entre convencionais e GMs. Nos resultados da espectrometria de massas foi possível reconhecer os principais grupos protéicos da soja, como as frações e subunidades de $\beta$-conglicinina e de glicinina, bem como os inibidores de proteases, aglutininas e lipoxigenases e não foi possível perceber alterações na expressão dos peptídeos identificados e analisados. Podemos concluir que as variações encontradas entre as três amostras convencionais e entre as amostras dos grupos convencionais e orgânicas foram maiores que a comparação das amostras GMs com suas genitoras correspondentes.

Palavras chaves: soja convencional, soja GM, soja orgânica, fatores antinutricionais, inocuidade alimentar, proteômica. 


\section{ABSTRACT \\ Proteomics analysis of conventional and genetically modified varieties of soybean (Glycine max) aiming bioactive proteins}

The glyphosate tolerant soybean is the most cultivated GM plant. However, questions about the bio-safety of GM foods are still rising, as there are uncertainty about the expression of new proteins, undesired mutations, changes in nutritional profile and the production of toxic compounds. Despite of the beneficial effects to human health, the soybean has anti-nutritional factors that can cause adverse physiological effects, reduce the bioavailability of nutrients, and induce hypersensitivity reactions. At the same time the soybean develop undesirable flavor due to the action of lipoxygenases. The anti-nutritional factors are related to agglutinins (lectins) and to the proteases inhibitors (Kunitz's Trypsin Inhibitor and Bowman-Birk's Inhibitor of Trypsin and Chymotrypsin) while the soybean globulins are responsible for hypersensitivity reactions. The objective of this work was to compare proteic maps of GM soybean, conventional isolines and organic soybean aiming to detect changes in protein profiles of the different types of cultivation and also analyze the expression of the antinutritional factors, such as protease inhibitors and agglutinins, taking into consideration the natural variation existing in the samples. For this, it was performed the comparisons between six seed samples of commercial varieties of soybeans, grown in parallel under the same environmental conditions and soil, composed of three parental isolines and their three corresponding GM and two organic sample, one of them is commercial and the other is still in search fields. The samples were provided by Embrapa Soja. Protein extracts were analyzed from the samples after extraction with trichloroacetic acid (TCA) and acetone using regular monodimensional electrophoresis (1D) and two-dimensional (2D) ones. For 2D were used strips of $\mathrm{pH}$ gradient 3-10 and the final images analyzed by ImageMaster 2D Platinum software. Several selected spots were identified by mass spectrometry. In the images of the 2D gels, we could identify and quantify the spots corresponding to proteins isolated and there was no statistical difference at $5 \%$ of significance between the different types of cultivation. Checking the overlap of the gels, we obtained matchings above $70 \%$ between GM and non GM sample. The organic sample had lower matching index between conventional and GM. It was possible to recognize the major groups of soy protein as a result of mass spectrometry such as $\beta$-conglycinin fractions and glycinin as well as protease inhibitors, lipoxygenase, and agglutinins. We concluded that the variations found among the tree conventional samples and between samples of conventional and organic groups were higher than the comparison of sample GMs with their corresponding parentals.

Keywords: conventional soybean, GM soybean, organic soybean, anti-nutritional factors, food safety, proteomics. 


\section{SUMÁRIO}

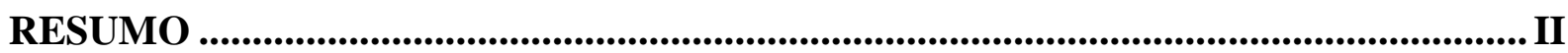

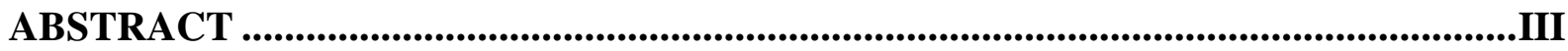

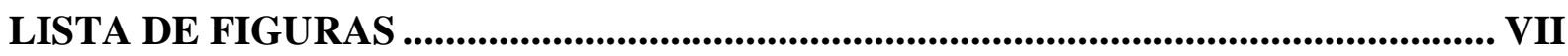

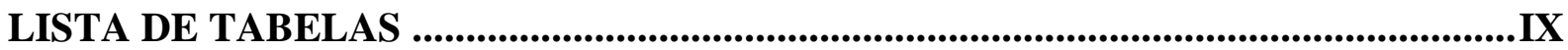

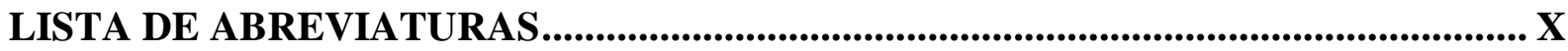

1. INTRODUÇÃO...................................................................................................................... 1

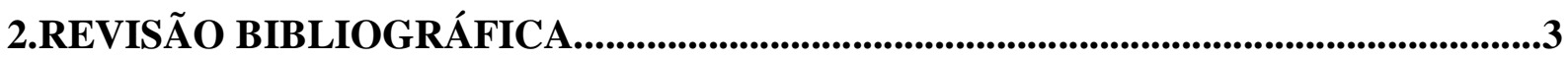

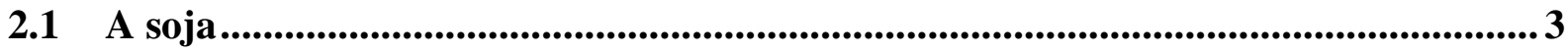

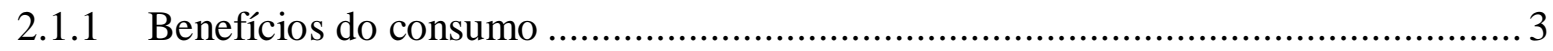

2.1.2 Características biológicas dos grãos ................................................................ 5

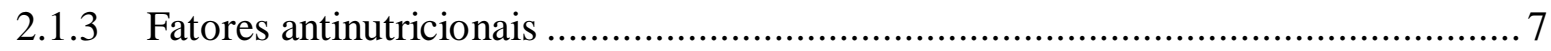

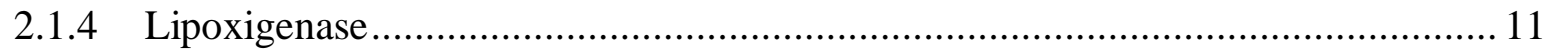

2.2 Culturas de plantas geneticamente modificadas................................................. 12

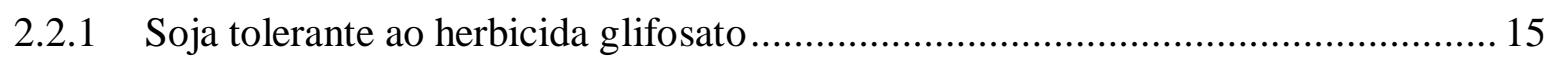

2.2.2 Biossegurança da soja geneticamente modificada ........................................ 17

2.3 Alimentos Orgânicos................................................................................................. 22

2.4 Análise protê̂mica.................................................................................................................... 26

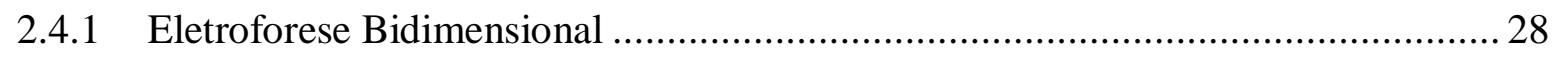

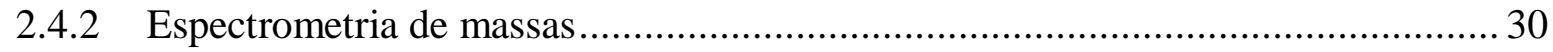

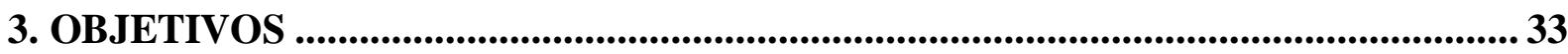

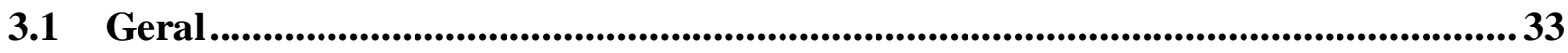

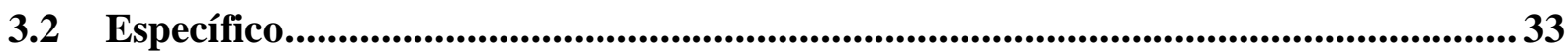




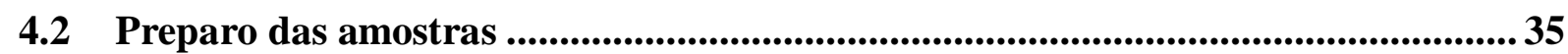

4.3 Extração e quantificação de proteínas ................................................................ 36

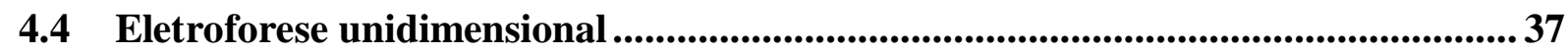

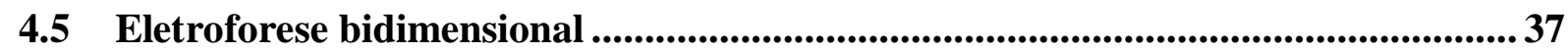

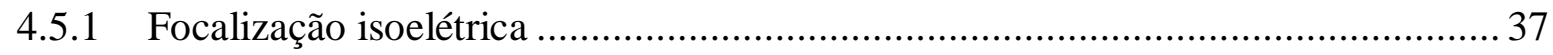

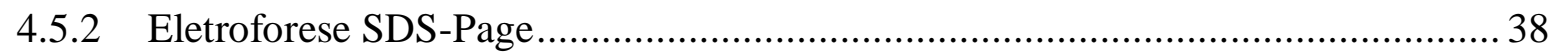

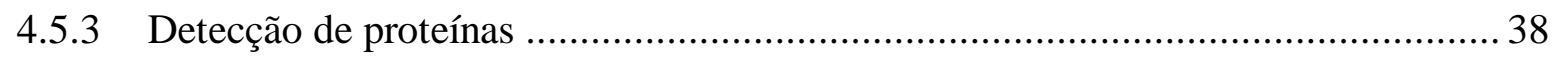

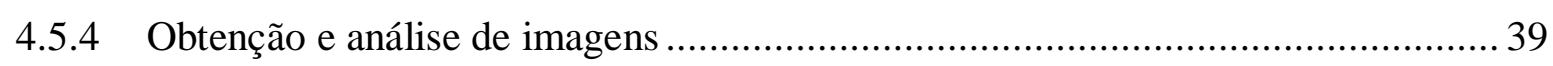

4.6 Identificação das proteínas ................................................................................... 39

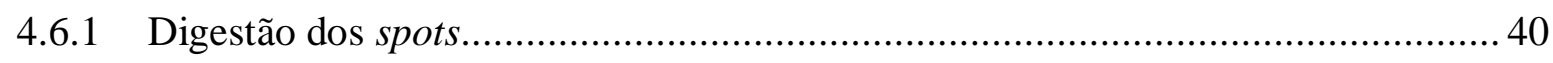

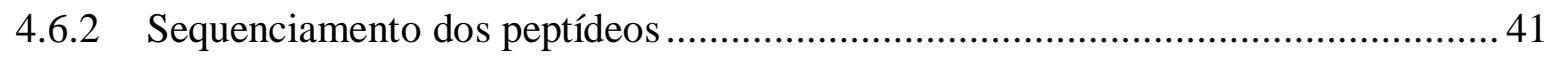

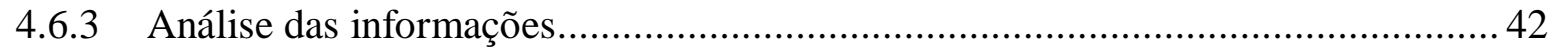

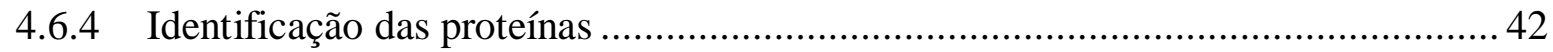

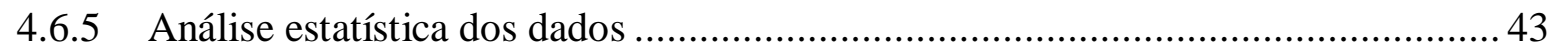

5. RESULTADOS E DISCUSSÃO............................................................................................44

5.1 Extrações de proteínas ....................................................................................................... 44

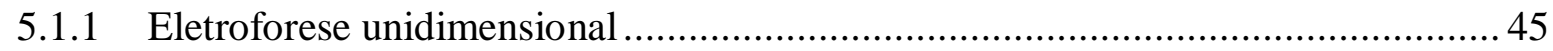

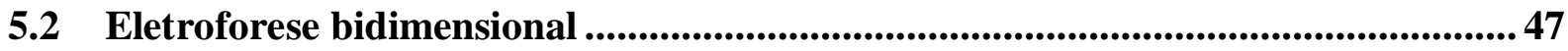

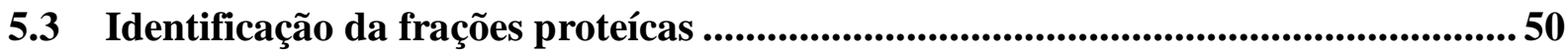

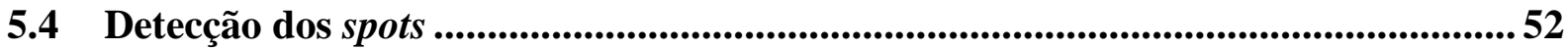

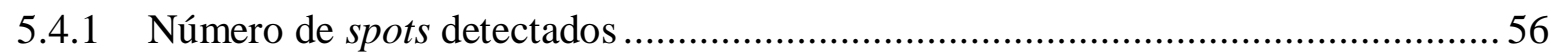

5.5 Matching entre extrações ......................................................................................5 59

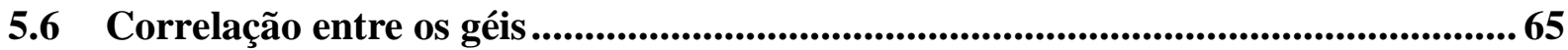

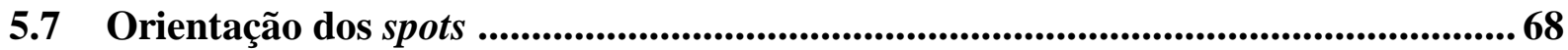

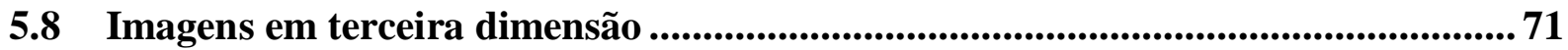


5.9 Eletroforese bidimensional de amostras orgânicas................................................. 72

5.10 Hipóteses de alterações não resultantes da transgenia ............................................. 76

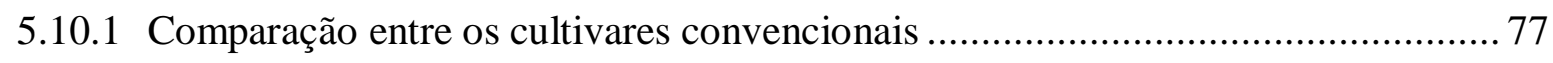

5.10 .2 Comparação entre diferentes formas de cultivo ........................................... 80

5.11 Identificação das proteínas por espectrometria de massas .................................. 85

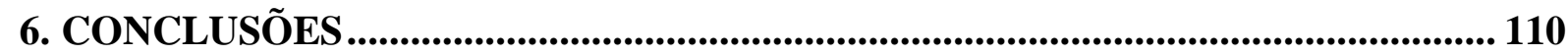

7.REFERÊNCIAS BIBLIOGRÁFICAS.........................................................................11 


\section{LISTA DE FIGURAS}

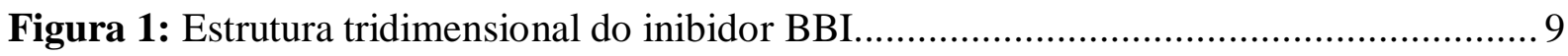

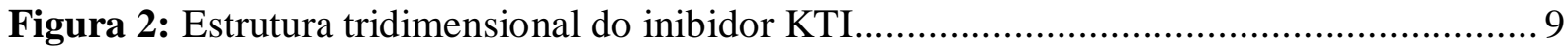

Figura 3: Estrutura tridimensional da aglutinina de soja. .............................................. 10

Figura 4: Reação de oxidação catalisada pela lipoxigenase.................................................11

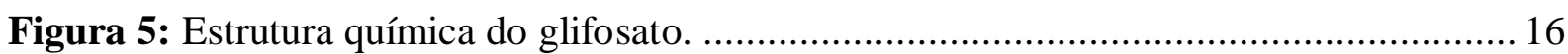

Figura 6: Mecanismo de ação do glifosato sobre a enzima EPSPS, bloqueando ou diminuindo a produção de aminoácidos para o desenvolvimento da planta................................... 17

Figura 7: Delineamento experimental da amostra 1, e que corresponde ao realizado para as

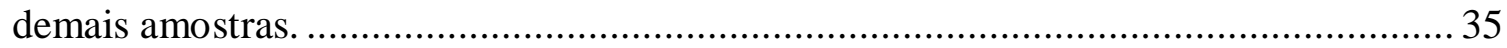

Figura 8: Seleção dos spots extraídos para análise por espectrometria de massas................. 40

Figura 9: Géis de 12\% de acrilamida corado com Coomassie G-250, resultante de corridas unidimensionais. 1,3 e 5 correspondem as amostras convencionais e 2,4 e 6 correspondem as amostras GM. A, B e C correspondem as extrações em triplicata de 30 $\mu \mathrm{g}$ de proteínas cada amostra. PM é o peso molecular em $\mathrm{kDA}$.

Figura 10: Eletroforese unidimensional, em gel 12\% corado com Coomassie G-250. Gel representa todas as amostras análisadas, sendo que 1, 3 e 5 são amostras convencionais enquanto que as amostras 2, 4 e 6 são as correspondentes geneticamente modificadas. . 46

Figura 11: Mapa protéico em gel bidimensional com faixa de $\mathrm{pH}$ de 3-10, com destaque para a fração ácida de glicinina. Gel preparado com 12\% de acrilamida e corado com Comassie G-250.

Figura 12: Mapa protéico em gel bidimensional com faixa de $\mathrm{pH}$ de 4-7, com destaque para a fração ácida de glicinina. Gel preparado com 12\% de acrilamida e corado com Comassie G-250.

Figura 13: Géis bidimensionais das amostras 1, 3 e 5 que representam amostras convencionais, e 2, 4 e 6 que representam amostras GM.

Figura 14: Spots detectados pelo software ImageMaster 2D Platinum a partir de geis bidimensionais com gradiente de $\mathrm{pH}$ de 3-10. As amostras 1,3 e 5 correspondem as amostras convencionais e as amostras 2, 4 e 6 correspondem as amostras GM......

Figura 15: Spots detectados pelo software ImageMaster 2D Platinum de gel bidimensional da amostra 1 com gradiente de $\mathrm{pH}$ de 4-7.

Figura 16: Matching entre a amostra convencional 1 e sua respectiva GM, amostra 2........ 62 
Figura 17: Matching entre a amostra convencional 3 e sua respectiva GM, amostra 4 63

Figura 18: Matching entre a amostra convencional 5 e sua respectiva GM, amostra $6 .$. 64

Figura 19: Gráficos de correlação da \% de intensidade entre a o gel referência da amostra genitora e o gel referência da sua correspondente GM. O primeiro compara amostra 1 e 2, o segundo compara 3 e 4, o terceiro compara amostra 5 e 6 .

Figura 20: Gráficos de correlação da \% de volume entre a o gel referência da amostra genitora e o gel referência da sua correspondente GM. O primeiro compara amostra 1 e 2, o segundo compara 3 e 4 , o terceiro compara amostra 5 e 6 . .

Figura 21: Orientação dos vetores em relação à localização dos spots. Comparação feita entre a amostra convencional (1, 3 e 5) e suas respectivas isolinhas GM (2, 4 e 6).

Figura 22: Imagem tridimensional (3D) dos picos de alguns dos principais grupos protéicos da soja, gerados a partir de géis bidimensionais de referência de cada amostra.. 71

Figura 23: Gráfico representativo da variação do número de spots nos diferentes tipos de cultivo. 73

Figura 24: Gráfico representativo da variação do número de spots nos diferentes amostras. Número 1, 3 e 5 são as amostras convencionais, 2, 4 e 6 amostras GMs e 7 e 8 amostras orgânicas.

Figura 25: Géis bidimensionais das amostras orgânicas, representando a sobreposição entre elas. 75

Figura 26: Imagens 1, 2 e 3 corresponde a sobreposição dos géis de referência das amostras convencionais 1,3 e 5 respectivamente

Figura 27: Imagens 1, 2 e 2 Orgânica correspondem a sobreposição dos géis de referência das amostras convencionais 1, GM 2 e orgânica 2 respectivamente

Figura 28: Imagens 3, 4 e 2 Orgânica correspondem a sobreposição dos géis de referência das amostras convencionais 3, GM 4 e orgânica 2 respectivamente

Figura 29: Imagens 5, 6 e 1 Orgânica correspondem a sobreposição dos géis de referência das amostras convencionais 5, GM 6 e orgânica 1 respectivamente. 83

Figura 30: Espectro TOF MS/MS do spot 1 da amostra 1. 86

Figura 31: Estrutura recombinante cristalina e nativa da $\beta$-conglicinina complexada com $\mathrm{N}$ acetil-D-glucosamina...... 100

Figura 32: Estrutura recombinante cristalina subunidade Pro-glicinina A3b4.................. 101

Figura 33: Aglutinina de soja complexada com 2,6 pentasacarídeo. 105

Figura 34: Gel bi-dimensional representando o mapa protéico identificado por espectrometria de massas. 


\section{LISTA DE TABELAS}

Tabela 1: Área global com lavouras GM em 2010 por país (em milhões de hectares) 14

Tabela 2: Variedades de soja recebidas pela Embrapa - Soja e denominação recebida em nosso laboratório. 34

Tabela 3: Parâmetros para busca de dados a partir dos espectros MS/MS. 42

Tabela 4: Número de spots detectados pelo software ImageMaster 2D Platinum para as diferentes amostras, extrações e suas triplicatas em géis de acrilamida $12 \%$, gradiente de pH 3-10.

Tabela 5: Número de spots detectados pelo software ImageMaster 2D Platinum para as diferentes amostras, extrações e suas triplicatas em géis de acrilamida $12 \%$, gradiente de $\mathrm{pH} 4-7$. 58

Tabela 6: Spots comuns entre as extrações das amostras em relação aos géis de referência.. 59

Tabela 7: Spots comuns entre diferentes amostras de soja convencional e suas correspondentes GM. 1, 3 e 5 correspondem as amostras convencionais e 2, 4 e 6 correspondem as amostras GM.

Tabela 8: Número de spots detectados pelo software ImageMaster 2D Platinum para as diferentes amostras orgânicas e suas respectivas extrações e triplicatas em géis de acrilamida $12 \%$, gradiente de $\mathrm{pH} 3-10$. 72

Tabela 9: Spots comuns entre as extrações das amostras orgânicas em relação ao gel referência.

Tabela 10: Spots comuns entre as diferentes amostras de soja orgânica. 75

Tabela 11: Tabela representativa da variabilidade natural existente entre as amostras. 77

Tabela 12: Número de spots comuns e \% de matching entre os diferentes tipos de cultivos. 81

Tabela 13: Número de spots comuns e \% de matching entre os diferentes tipos de cultivos..82

Tabela 14: Número de spots comuns e \% de matching entre os diferentes tipos de cultivos. 83 


\section{LISTA DE ABREVIATURAS}

1D Eletroforese Unidimensional

2D Eletroforese Bidimensional

ACN Acetonitrila

AMBIC Bicarbonato de amônio

BBI Inibidor Bowman-Birk

BSA Albumina de soro bovino

CTNBio Comissão Técnica Nacional de Biossegurança

DTT Ditiotreitol

EPSPS 5-enolpiruvilchiquimato-3-fosfato sintase

GM Geneticamente Modificado

IPG Immobilized $\mathrm{pH}$ gel

KTI Inibidor de tripsina Kunitz

LC-MS/MS Liquid chromatography mass spectrometry

MS Espectrometria de Massas

MSDB Mass Spectrometry protein sequence Data Base

pI Ponto Isoelétrico

PM Peso Molecular

RR Roundup Ready

SDS Dodecil Sulfato de Sódio

SDS-PAGE Eletroforese em Gel de Poliacrilamida - Dodecil Sulfato de Sódio

TCA Ácido Tricloroacético 


\section{INTRODUÇÃO}

O cultivo de plantas geneticamente modificadas (GM) atingiu em 2010 um recorde de 15,4 milhões de agricultores e que se estima corresponder a uma área total de 148 milhões de hectares plantados. Na colheita de 2008 para 2009, o Brasil teve um crescimento exponencial dos seus cultivares GMs que correspondem à soja, milho e algodão, ultrapassando a Argentina, tornando-se o segundo maior produtor do mundo de cultura GM, ficando atrás apenas dos Estados Unidos. De 2009 para 2010 o Brasil aumentou mais 4 milhões de hectares de área plantada de cultura GM totalizando 25,4 milhões de hectares.

Com o advento da biotecnologia voltada para o desenvolvimento de plantas, diversos alimentos novos e geneticamente modificados (GM) têm sido introduzidos no mercado. Os críticos da tecnologia GM levantam questionamentos à cerca das incertezas sobre a expressão de novas proteínas, a possibilidade de ocorrência de mutações, alterações na composição de nutrientes e a produção indesejada de componentes tóxicos ou alergênicos. Para a comercialização desses novos produtos, a inocuidade alimentar deve ser garantida através de estudos comparativos em diversos níveis. A equivalência substancial, primeira proposta de avaliação de segurança dos novos alimentos, é considerada até o presente uma importante ferramenta para essa comprovação, porém, o desenvolvimento de novos sistemas analíticos se torna necessário para detecção de alterações mais complexas nos novos OGMs. Entre as novas metodologias podemos citar a proteômica, genômica, metabolômica e a nutrigenômica.

A soja tolerante ao herbicida glifosato foi uma das primeiras aplicações da engenharia genética na agricultura. Foi desenvolvida pela inserção de um cassete com o gene cp4, que codifica a enzima 5-enolpiruvilchiquimato-3-fosfato sintase (EPSPS), que é alvo do herbicida glifosato.

A soja (Glycine max) contém em sua composição aproximadamente $40 \%$ de proteínas, destas, destacam-se dois grandes grupos protéicos, a glicinina e a $\beta$-conglicinina, que juntas representam cerca de 70 a $80 \%$ das proteínas da soja. Ambas são as principais responsáveis pelas propriedades físico-químicas e funcionais da soja em alimentos industrializados, bem como respondem pela quase totalidade das características nutricionais dessa leguminosa. 
Cerca de 7\% das proteínas da soja correspondem aos inibidores de proteases conhecidos como Kunitz e Bowman-Brik, enzima lipoxigenase e lectinas. Estes estão associados a variados mecanismos de resistência aos ataques de organismos patogênicos e herbívoros, tendo efeito protetor das plantas contra estes danos, podendo reduzir significativamente a atividade hidrolítica de proteases presentes no intestino dos insetos. Os inibidores de proteases e as lectinas apresentam atividades antinutricionais e podem provocar efeitos fisiológicos adversos ou diminuir a biodisponibilidade de nutrientes para os seres humanos.

No presente trabalho analisamos amostras de grãos de variedades comerciais de soja, isogênicas e GM, cultivadas em paralelo, sob as mesmas condições ambientais e de solo, fornecidas pela Embrapa Soja - Londrina, e comparamos com seis amostras experimentais anteriormente estudadas no nosso laboratório. Paralelamente, avaliamos também duas variedades orgânicas. Pretendemos através das técnicas proteômicas identificar por espectrometria de massas possíveis alterações na composição protéica de variedades GM em relação ao mapa de variedades convencionais e orgânicas. Uma atenção especial é dada aos inibidores de proteases, lectinas e às lipoxigenases. 


\section{REVISÃO BIBLIOGRÁFICA}

\subsection{A soja}

A planta de soja é uma dicotiledônea herbácea pertencente à família Fabaceae, subfamília Papilionoideae e ao gênero Glycine L., que compreende 15 espécies. Tais plantas podem atingir até $1,5 \mathrm{~m}$ de altura, são de crescimento ereto e cerrado. A planta apresenta basicamente dois estágios de desenvolvimento, o vegetativo (estabelecimento e desenvolvimento) e reprodutivo (florescimento e maturação) (ASSUPÇÃO, 2008). Em geral, as sementes de soja apresentam-se nas cores amarela, preta e verde, porém, devido a interesses industriais, as cultivares amarelas são as mais produzidas (DIXIT et al., 2010).

A soja, provavelmente nativa da China, é cultivada a cerca de 5 mil anos. Chegou ao Brasil com os primeiros imigrantes japoneses em 1908, porém, somente na década de 70 houve a expansão de sua produção (FRIEDMAN; BRANDON, 2001).

Atualmente os Estados Unidos são o maior produtor de grãos de soja. Na safra 2008/2009 sua produção foi de 80,5 milhões de toneladas. O segundo maior produtor é o Brasil que na safra 2008/2009 produziu 57,1 milhões de toneladas. Em seguida estão Argentina e a China, como terceiro e quarto maiores produtores mundiais. Juntos os quatro países respondem por cerca de $90 \%$ da produção mundial. O Mato Grosso é o maior produtor de soja do Brasil, seguido do Paraná. Suas colheitas na safra 2008/2009 foram de 17,963 e 9,510 milhões de toneladas, respectivamente (EMBRAPA, 2011).

A área plantada com culturas convencionais de soja tem diminuído anualmente, enquanto que a cultura da soja resistente ao herbicida glifosato aumentou significativamente devido a ampla adoção desse defensivo nos sistemas atuais de manejo de plantas daninhas (ZOBIOLE et al., 2010).

\subsubsection{Benefícios do consumo}

A soja é um alimento de elevado valor protéico, fornecedor de ácidos graxos saturados e insaturados, algumas vitaminas, além de possuir compostos polifenólicos, como as isoflavonas (FRIEDMAN; BRANDON, 2001; ÁVILA, 2007). É tradicional seu consumo 
entre os povos orientais, onde foi e continua sendo amplamente cultivada para servir de matéria prima na obtenção de produtos típicos de suas dietas. Apesar desta leguminosa ainda não fazer parte da dieta habitual da maioria dos brasileiros, seu consumo vem se estendendo para os países do Ocidente. Além de servir para fabricação de alimentos para seres humanos, alimentação animal, resinas, ainda serve como fonte de biocombustível (KOMATSU; AHSAN, 2009).

O motivo pelo qual a soja ainda sofre restrições de consumo nos países ocidentais pode estar relacionado ao seu sabor e aroma desagradáveis ao nosso paladar, característica conhecida como beany flavor (MONTEIRO et al., 2004). As lipoxigenases (LOX) são as responsáveis por este aroma (BARROS et al., 2008), elas catalizam reações de hidroperoxidação de ácidos graxos polinsaturados formando compostos carbonílicos de cadeia curta que se ligam as frações protéicas, e essa associação dá origem ao beany flavor (AXELROD; CHEESBROUGH; LAAKSO 1981).

A partir de evidências científicas, obtidas de análise dos teores de colesterol de populações asiáticas em função do alto consumo de soja (CROUSE et al., 1999), a agência FDA (Food and Drug Administration) em 1999 reconheceu a proteína de soja como um alimento funcional, sob a alegação de que a ingestão de uma dieta pobre em gordura saturada e em colesterol, associada ao consumo de $25 \mathrm{~g}$ de proteína de soja por dia, poderia reduzir o risco de doenças cardiovasculares (FDA, 1999). Em 2002, no Brasil, a Agência Nacional de Vigilância Sanitária também aprovou a alegação do consumo de $25 \mathrm{~g}$ proteína de soja como alimentos funcional, desde que associado a dieta equilibrada e hábitos de vida saudáveis, podendo ajudar a reduzir o colesterol (ANVISA, 2002).

Além do estudo já comprovado de que o consumo de soja reduz LDL (REYNOLDS et al., 2006; SIRTORI; EBERINI; ARNOLDI, 2007), existem vários estudos que apontam outros efeitos positivos, como a redução do câncer de mama, próstata e cólon (CROUSE et al., 1999), melhoria da função endotelial, redução de triglicerídeos e colesterol total, melhora dos sintomas climatéricos (GENOVESE et al., 2003; JOU; LING; WU, 2005; GENOVESE; HASSIMOTTO; LAJOLO, 2005), entre outros.

Após tais descobertas, muitas indústrias interessadas nas propriedades físicoquímicas que os grãos apresentam e também neste nicho de mercado que busca produtos que tragam benefícios à saúde, houve um aumento na produção de alimentos a base de soja como leite de soja e tofu, ou com adição de soja em suas formulações como em sopas, bolachas, pães, bebidas, etc. Para isso a indústria vem melhorando suas tecnologias para obtenção de 
produtos com melhores características sensoriais e, consequentemente, maior aceitação da população em geral.

\subsubsection{Características biológicas dos grãos}

O grão de soja contém cerca de $40 \%$ de proteínas (KRISHNAN et al., 2007). Destas, as que se apresentam em maiores quantidades são as proteínas de reserva glicinina e $\beta$-conglicinina, com cerca de 70\% (HILL; BREIDENBACH, 1974; KRISHNAN, et al., 2007; L'HOCINE; BOYE; JOUVE, 2007; CARRÃO-PANIZZI et al., 2008). Acrescentam-se ainda cerca de 7\% correspondentes às lipoxigenases, inibidor de tripsina Kunitz e inibidor de protease Bowman-Birk, lectinas e ureases (FRIEDMAN; BRANDON, 2001).

Dentre as proteínas da soja, 70-90\% são globulinas e as demais são albuminas. Recebem essa classificação pelo tipo de extração e sua respectiva solubilidade. No caso, as globulinas são as proteínas solúveis em soluções salinas enquanto que as albuminas são solúveis em água (SHEWRY; NAPIER; TATHAM, 1995). Dependendo do perfil de sedimentação, as diferentes cadeias polipeptídicas foram classificadas em 7S e 11S (que correspondem às maiores frações na soja) e ainda 2S e 15S (HILL; BREIDENBACH, 1974; SHEWRY; NAPIER; TATHAM, 1995).

A glicinina é a proteína de reserva mais abundante na soja, apresenta coeficiente de sedimentação 11S. Possui seis subunidades e peso molecular de $350 \mathrm{kDa}$; cada subunidade é composta de polipeptídios ácidos e básicos, que são ligados entre si por ligações dissulfeto (STASWISK; HERMODSON; NIELSEN, 1984). Até o momento, as subunidades conhecidas da glicinina são: A1aB2, A1bB1b, A2B1a, A3B4 e A5A4B3 (MORAES et al., 2006; L'HOCINE; BOYE; JOUVE, 2007; NATARAJAN et al., 2007 ${ }^{\mathrm{A}}$ ).

A $\beta$-conglicinina é a segunda proteína de reserva mais abundante na soja, apresenta coeficiente de sedimentação 7S e peso molecular de $180 \mathrm{kDa}$. É uma proteína trimérica, composta pelas subunidades alfa' $\left(\alpha^{\prime}\right)$, alfa $(\alpha)$ e beta $(\beta)$ (THANH; SHIBASAKI, 1978).

Carrão-Panizzi e colaboradores (2008) avaliaram os efeitos da variação genética e ambiental sobre os teores de $\beta$-conglicinina e glicinina em cultivares de sojas brasileiras e observou variabilidade significativa quanto à razão entre as frações protéicas da $\beta$-conglicinina (7S) e da glicinina (11S), entre as 90 cultivares avaliadas. Porém como 
analisou locais diferentes de semeadura, não foi possível avaliar quais componentes ambientais tiveram impacto na concentração das frações estudadas.

A proteína de soja não é uma proteína ideal, porque apresenta teor reduzido de aminoácidos sulfurados: metionina e cistina (FRIEDMAN; BRANDON, 2001). Moraes e colaboradores (2006) avaliaram a qualidade nutricional das linhagens de soja obtidas por melhoramento genético. Embora a glicinina contenha 3 a 4 vezes mais resíduos de metionina por unidade de proteína do que a $\beta$-conglicinina, o conteúdo protéico da soja é deficiente de aminoácidos sulfurados, estimulando os autores a sugerir o aumento da razão de glicinina: $\beta$ conglicinina para melhorar a qualidade nutricional dos grãos.

Os principais componentes da soja que estão associados aos benefícios à saúde são as isoflavonas, que apresentam formas, teores e atividades variáveis no grão (ALTAWAHA et al., 2007). As principais isoflavonas encontradas na soja e seus derivados são daidzeína, genisteína e gliciteína (ESTEVES; MONTEIRO, 2001; KUHNLE et al., 2009). Existem 12 tipos de isoflavonas, divididas em agliconas, gliconas e seus conjugados glicosídeos malonil e acetil. As isoflavonas livres sem a molécula de açúcar, denominadas agliconas, são consideradas mais importantes presentes na soja. Entre elas, a daidzeína e a genisteína têm se destacado em virtude do seu maior potencial protetor à saúde humana (ALEZANDRO et al., 2008).

As isoflavonas pertencem ao grupo dos fitoestrógenos, que são um grupo de metabólitos de vegetais com características não-esteróides e polifenólicos, que induzem a resposta biológica e podem imitar ou modular a ação dos estrogênios endógenos, muitas vezes através da ligação aos receptores de estrogênio (KUHNLE et al., 2009), possuem estrutura química semelhante ao $17 \beta$-Estradiol (GENOVESE; LAJOLO, 2001; IWASAKI; TSUGANE, 2011).

Os efeitos das isoflavonas são variáveis nos diferentes tecidos devido à afinidade por receptores específicos (ESTEVES; MONTEIRO, 2001). Ramos (2007) avaliou o efeito dos flavonóides, entre eles a genisteína da soja, como compostos anticarcinogênico e concluiu que são moléculas bioativas capazes de interferir no desenvolvimento do câncer, modulando a proliferação celular, diferenciação, apoptose, angiogênese e matástase. No entanto, o mecanismo de ação das isoflavonas não está totalmente elucidado, mas acredita-se que esteja associado a efeitos estrogênicos e antiestrogênicos, regulação da atividade de proteínas, regulação de ciclos celulares e efeitos antioxidantes (ESTEVES; MONTEIRO, 2001). 
Em uma recente revisão da literatura, Iwasaki e seus colaboradores (2011) encontraram uma heterogeneidade de resultados para fatores de risco e evidências epidemiológicas para câncer, mas constataram que a maior ingestão de isoflavonas e maiores níveis de genisteína no plasma estão associados a uma diminuição do risco de câncer de mama (IWASAKI et al, 2011).

Em continuidade às pesquisas no tema, foi publicado um estudo que relaciona as isoflavonas na quimioprevenção do câncer de próstata, no qual há evidências de efeito positivo. No entanto, serão necessários mais estudos para elucidar as vias de sinalização celular que estão envolvidas nos mecanismos preventivos das isoflavonas (SZLISKA et al., 2011).

\subsubsection{Fatores antinutricionais}

A soja, como citado anteriormente, apresenta um conteúdo protéico de cerca de $40 \%$ do grão em peso seco. Deste percentual, uma pequena parte compreende aos fatores antinutricionais, que são os inibidores de proteases (inibidor de tripsina Kunitz, ou KTI, e inibidor de protease Bowman-Birk, ou BBI), lectinas, oligossacarídeos, saponinas e fitatos (FRIEDMAN; BRANDON, 2001; KRISHNAN; KIM, 2003).

Os fatores antinutricionais da soja geralmente são eliminados com um correto tratamento térmico. Porém, Friedman e colaboradores (1991) demonstraram que pode ser encontrada atividade residual de 10 a $15 \%$ de inibição de proteases em produtos de soja, mesmo após tratamento térmico, característica esta imputada à estrutura molecular compacta estabilizada por ligações dissulfeto.

Cardoso e colaboradores (2007) realizaram estudos comparativos para verificação da atividade inibitória da tripsina e quimotripsina e a verificação da eliminação genética na atividade destes inibidores em genótipos de soja, os resultados obtidos demonstraram um menor tempo necessário de processamento térmico para a redução da atividade inibitória de tripsina. $\mathrm{O}$ processamento térmico de $120^{\circ} \mathrm{C}$ por 9 minutos foi suficiente para a completa inativação dos inibidores nas variedades isentas de KTI (CARDOSO et al., 2007). 


\subsubsection{Inibidores de proteases}

Dentre os fatores antinutricionais da soja, os mais investigados são os inibidores de proteases. $\mathrm{O}$ inibidor de tripsina bloqueia a ação da tripsina resultando em aumento excessivo da concentração plasmática do hormônio colecistoquinina, e desta forma, o pâncreas é continuamente estimulado a liberar mais enzima, podendo provocar hipertrofia pancreática (FRIEDMAN; BRANDON, 2001; CARDOSO et al., 2007). A colecistoquinina é o hormônio mediador da liberação de tripsina; assim, sempre que o nível de tripsina está baixo as células endócrinas do jejuno liberam a colecistoquina (LIENER, 1995).

Os autores (FRIEDMAN; BRANDON, 2001) sugerem estudos epidemiológicos adicionais com humanos para pesquisa de possíveis efeitos adversos em longo prazo sobre o pâncreas, levando em consideração o aumento do consumo de produtos a base de soja. No entanto, nos últimos 10 anos não houve relatos desse tipo de acompanhamento em humanos.

Na soja são encontrados 2 tipos de inibidores de proteases: inibidor de protease tipo Kunitz (KTI) e inibidores de proteases Bowman-Birk (BBI). O KTI inibe a tripsina, enquanto que o BBI apresenta especificidade para inibir tripsina e quimotripsina (FRIEDMAN et al., 1991). Na soja encontra-se três vezes mais KTI do que BBI (TANWILSON, 1988). Cerca de $80 \%$ da inibição tríptica acontece pela ação do KTI (MONTEIRO et al., 2004).

O KTI apresenta peso molecular de $20 \mathrm{kDa}$ e duas pontes dissulfetos, enquanto que o BBI apresenta peso molecular de 6 a $10 \mathrm{kDa}$ e sete ligações dissulfetos (Figura 1 e 2). Essas características influenciam diretamente na estabilidade térmica, pois a desnaturação dos inibidores esta relacionada ao rompimento das ligações dissulfeto. Desta maneira, o BBI é mais estável ao calor e a variações de pH do que o KTI (FRIEDMAN et al., 1991). Ao mesmo tempo, quanto maior o número de pontes $\mathrm{S}-\mathrm{S}$ mais difícil se torna a ação de proteases. 


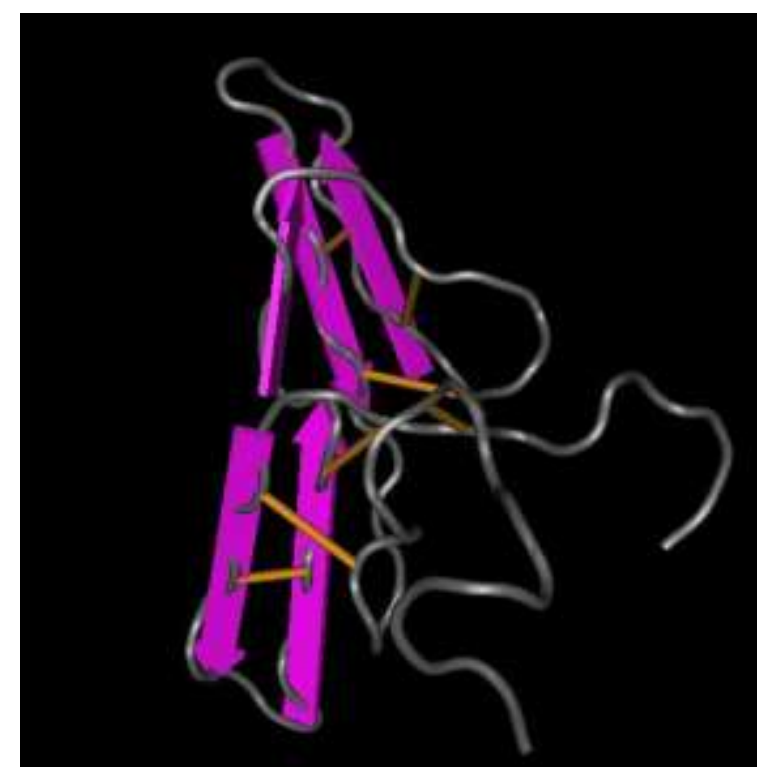

Figura 1: Estrutura tridimensional do inibidor BBI, destaque na cor laranja para as sete ligações dissulfetos. Fonte: Banco de dados NCBI - National Center for Biotechnology Information.

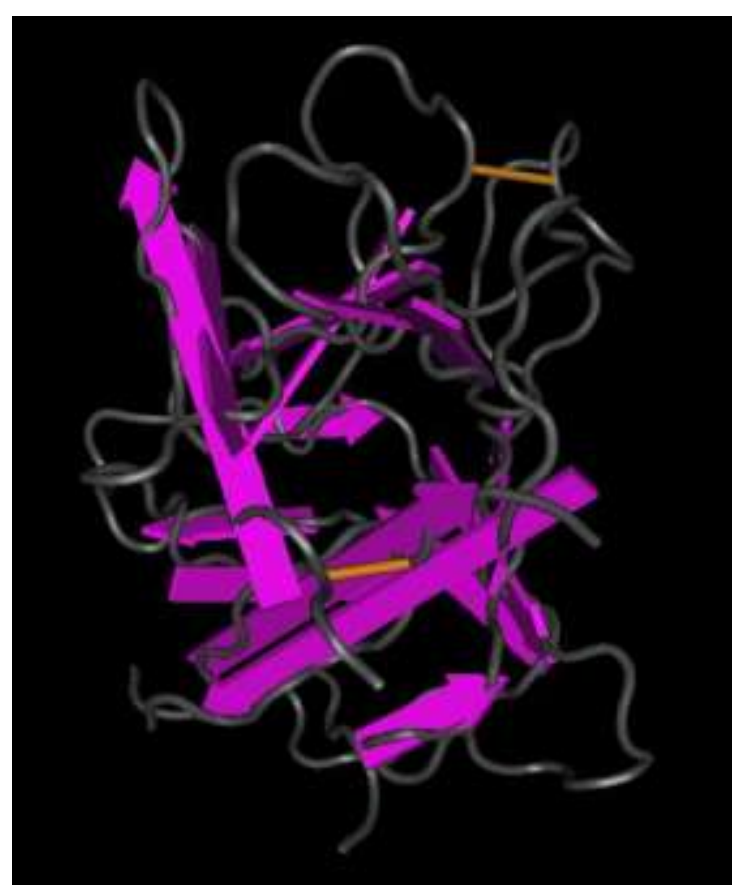

Figura 2: Estrutura tridimensional do inibidor KTI, destaque na cor laranja para as 2 ligações dissulfetos. Fonte: Banco de dados NCBI - National Center for Biotechnology Information. 


\subsubsection{Lectinas}

Numa definição antiga, as lectinas são classificadas como proteínas não pertencentes ao sistema imunológico, porém capazes de reconhecer sítios específicos de moléculas e ligarem-se a carboidratos, sem alterar a estrutura covalente das ligações glicosídicas dos sítios (ETZLER, 1985).

As lectinas são amplamentes distribuídas na natureza e apresentam a capacidade de se ligar à superfície de células, com alta especificidade para os oligossacarídeos e glicopeptídeos (GEORGE et al., 2008). Podem se ligar a carboidratos e glicoconjugados sobre a superfície epitelial do intestino, interferindo com a absorção de nutrientes (LAJOLO; GENOVESE, 2002). A lectina de soja é conhecida como aglutinina de soja (SBA) (Figura 3).

A lectina é um fator antinutricional, conhecido por reduzir a qualidade protéica do grão de soja (MACHADO et al., 2008). As funções das lectinas nas plantas são variadas e parecem ter relação com a maturação e germinação das sementes bem como na defesa da planta contra o ataque de fungos (LIENER et al., 1974).

Os efeitos tóxicos das lectinas geralmente podem ser eliminados por tratamento térmico apropriado (SILVA; SILVA, 2000). Porém com calor úmido pode-se perceber uma atividade residual de 10-20\% e com calor seco percebeu-se que as lectinas foram resistentes a inativação (LIENER et al., 1974).

George e colaboradores (2008) sugerem o desenvolvimento de cultivares com baixos teores de lectinas para melhorar a qualidade nutricional do grão, no entanto tal mudança poderá acarretar aumento de vulnerabilidade ao ataque de pragas e predadores.

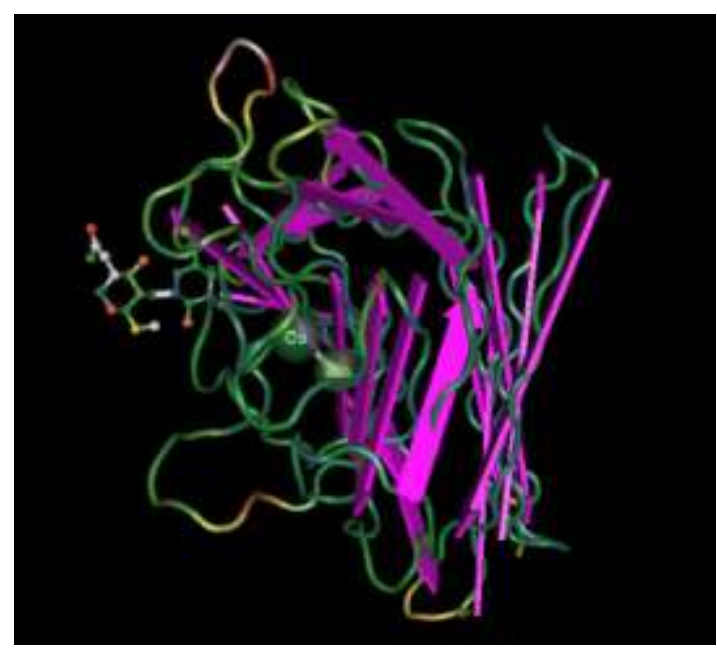

Figura 3: Estrutura tridimensional da aglutinina de soja.

Fonte: Banco de dados NCBI - National Center for Biotechnology Information. 


\subsubsection{Lipoxigenase}

As lipoxigenases não são fatores antinutricionais, porem são capazes de catalisar reações desfavoráveis no aspecto de palatabilidade do grão. Portanto, alterações genéticas nas quais essas enzimas fossem silenciadas seriam interessantes para aumento do seu consumo por parte da população (MONTEIRO et al., 2004).

As lipoxigenases (LOX) são isoenzimas que catalisam a adição de oxigênio aos ácidos graxos poliinsaturados, formando hidroperóxidos de ácidos graxos (AXEROLD; CHEESBROUGH, 1981). As LOXs correspondem a cerca de 1\% das proteínas da soja (MONTEIRO et al., 2004).

As LOXs são produzidas no início da germinação das sementes e pelo menos seis isoenzimas LOX foram encontradas na soja (IASSONOVA et al., 2009) e estão identificadas como LOX 1-6. As LOX-1, LOX-2 e LOX-3 são proteínas longas com peso molecular de 103 kDa (PRIGGE et al., 1997) e são encontradas em proteínas da semente de soja. As demais LOXs são encontradas nos tecidos da planta e acredita-se que fazem parte do mecanismo de defesa da planta (IASSONOVA et al., 2009).

$\mathrm{Na}$ soja, a reação de hidroperixodação (Figura 4) ocorre com o ácido linoléico (C18:2) e linolênico (C18:3). Dos ácidos graxos da soja, em torno de 57\% corresponde ao ácido linoléico, de 7 a 9\% ao ácido linolênico (KITAMURA et al., 1983).

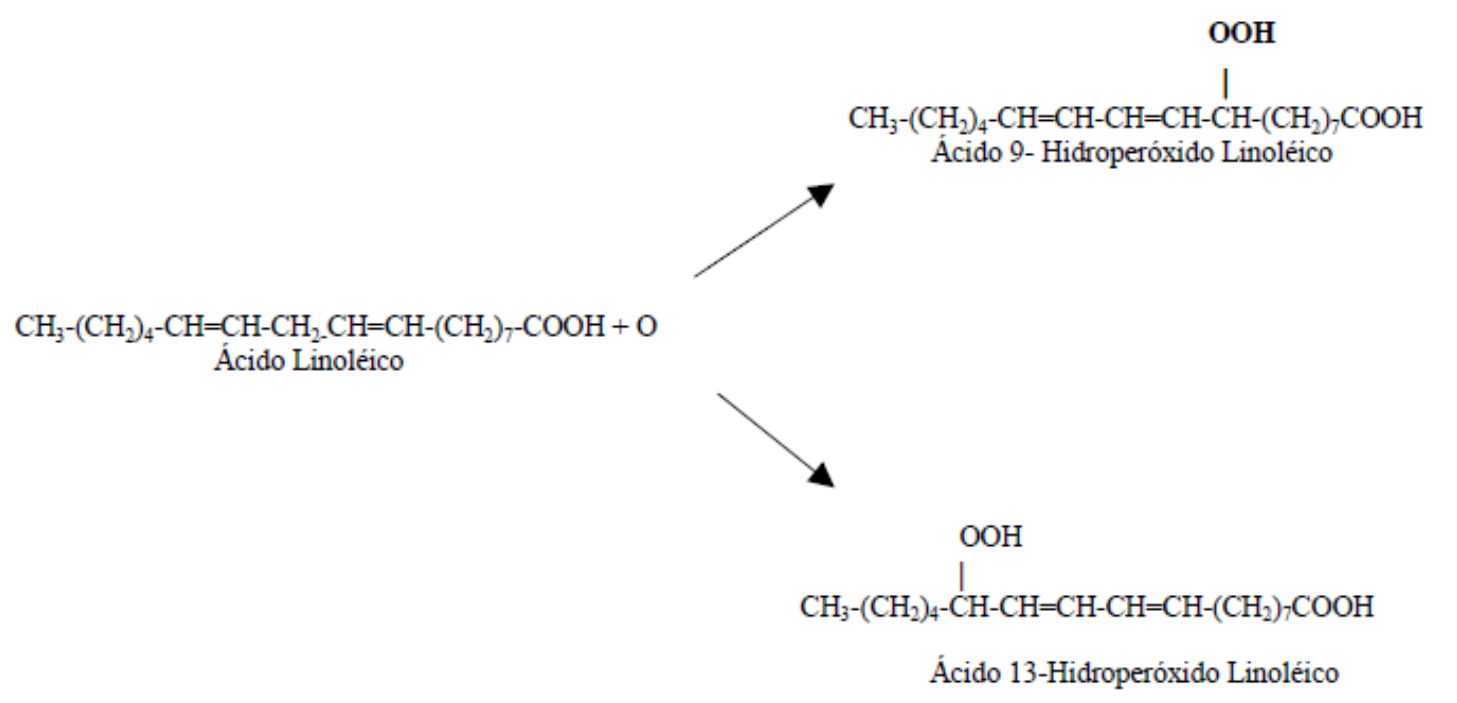

Figura 4: Reação de oxidação catalisada pela lipoxigenase. Neste caso o substrato é o ácido linoléico e os produtos formados são o ácido 9 e 13 hidroperóxido linoléico. Adaptado de Frankel, 2005. 
A função das LOXs é um pouco obscura, mas sabe-se que os compostos que são produzidos podem ajudar no desenvolvimento e proteção de mudas (IASSANOVA et al., 2009). Em situações de danos nas plantas, as LOX atuam em resposta a ferimentos e resistência a insetos e patógenos. Nestes casos, os hidroperóxidos de ácidos graxos são metabolizados para formar compostos como traumatina, ácido jasmônico, aldeídos voláteis que atuam de diferentes formas em defesa da planta danificada (RICKERT; KLINMAN, 1999).

As LOXs de armazenamento das sementes são conhecidas por conter um átomo de ferro que é essencial para a atividade enzimática (IASSONOVA et al., 2009). A reação teria início com a oxidação de $\mathrm{Fe}^{2+}$ da enzima para $\mathrm{Fe}^{3+}$.

$\mathrm{Na}$ germinação das sementes há um aumento de hidroperóxidos nos lipídios armazenados, pois, detecta-se a presença de lipoxigenases na camada fosfolipídica dos corpos lipídicos. Esta enzima antecede a ação de lipases, oxidando ácidos graxos esterificados (OLIVEIRA et al., 2006). A peroxidação dos ácidos graxos polinsaturados pela ação das LOX leva a produção de hidroperóxidos que por reações subseqüentes produzem aldeídos e cetonas de cadeia curta que se ligam as frações protéicas, essa associação altera a palatabilidade reduzindo a aceitação da soja (AXELROD; CHEESBROUGH, 1981).

\subsection{Culturas de plantas geneticamente modificadas}

Fazendo uma rápida análise da população mundial em 1800, quando não passava de 1 bilhão de habitantes e atualmente está próxima de 7 bilhões, é possível perceber que são necessárias medidas para prover condições básicas de sobrevivência como água e alimentação às futuras gerações.

A constante preocupação com o crescimento exponencial da população mundial juntamente com as questões sócio-econômicas, sobretudo de países subdesenvolvidos, onde a pobreza impossibilita o acesso ao alimento, são fatores que justificam a busca de novas tecnologias para aumentar a produção de fontes alimentícias de boa qualidade nutricional e em maiores quantidades.

Uma alternativa para suprir essas questões é o melhoramento genético convencional. As plantas GM e seus produtos derivados destinados à alimentação foram as primeiras a ter destaque mundial em função da importância econômica que representam. As 
plantas produtoras de grãos têm sido modificadas por meio da inserção de genes que expressam características agronômicas, tais como tolerância a herbicidas e ou resistência a insetos (KÖNIG et al., 2004). Mais recentemente, o emprego de duas ou mais variedades GM cruzadas por melhoramento clássico podem resultar em plantas com múltiplas características de manejo, além de tentativas para aumentar o teor de proteínas dos grãos (JAMES, 2009; KRISHNAN et al., 2007). No caso da soja, um dos principais obstáculos ao aumento do conteúdo protéico por meio do cruzamento seletivo encontra-se na relação inversa existente entre teor de proteína e rendimento (KRISHNAN et al., 2007).

Em 2010, o cultivo de plantas geneticamente modificadas foi atingido por 15,4 milhões de agricultores, tanto pequenos e com recursos escassos, quanto grandes produtores, impulsionados pelos consistentes benefícios econômicos, ambientais e de bem estar social que a cultura oferece. Isto significou uma área total estimada em 148 milhões de hectares com culturas GM. Avanços também foram feitos em diversas outras frentes importantes no período, com novos países com culturas GM (atualmente são 29 países) e a adoção de culturas com genes combinados, procedimento também conhecido como piramidação, entre outros (JAMES, 2010). Acredita-se que em breve culturas resistentes à seca e à salinidade do solo sejam introduzidas, para contribuir na superação de alguns dos principais desafios enfrentados pelos países em desenvolvimento, como no preço dos alimentos, na sustentabilidade do processo produtivo e, sobretudo, nos esforços para o alívio da pobreza e da fome.

Em 2009, a área cultivada conjunta de soja, milho e algodão geneticamente modificados no Brasil levou a um crescimento nacional de 35\% sobre o ano de 2008, equivalente a 21,4 milhões de hectares, o que fez com que o Brasil se tornasse, pela primeira vez, o país número dois do mundo em termos de área plantada com espécies agrícolas biotecnológicas (JAMES, 2009). De 2009 para 2010 o Brasil aumentou mais 4 milhões de hectares de superfície com cultura GM totalizando 25,4 milhões de hectares e mantendo a segunda posição de produção de plantas GMs no mundo (JAMES, 2010), como pode ser visto na Tabela a seguir: 
Tabela 1: Área global com lavouras GM em 2010 por país (em milhões de hectares)

\begin{tabular}{|c|c|c|c|}
\hline RANK & PAÍS & $\begin{array}{c}\text { ÁREA } \\
\text { (milhões de ha) }\end{array}$ & LAVOURAS GM \\
\hline 1 & EUA & 66,8 & $\begin{array}{l}\text { Milho, Soja, Algodão, Canola, Beterraba, Alfafa, } \\
\text { Mamão, Abobrinha }\end{array}$ \\
\hline 2 & Brasil & 25,4 & Soja, Milho, Algodão \\
\hline 3 & Argentina & 22,9 & Soja, Milho, Algodão \\
\hline 4 & Índia & 9,4 & Algodão \\
\hline 5 & Canadá & 8,8 & Canola, Soja, Milho, Beterraba \\
\hline 6 & China & 3,5 & Algodão, Mamão, Poplar, Tomate, Pimenta \\
\hline 7 & Paraguai & 2,6 & Soja \\
\hline 8 & Paquistão & 2,4 & Algodão \\
\hline 9 & África do Sul & 2,2 & Milho, Soja, Algodão \\
\hline 10 & Uruguai & 1,1 & Soja, Milho \\
\hline 11 & Bolívia & 0,9 & Soja \\
\hline 12 & Austrália & 0,7 & Algodão, Canola \\
\hline 13 & Filipinas & 0,5 & Milho \\
\hline 14 & Mianmar & 0,3 & Algodão \\
\hline 15 & Burquina Faso & 0,3 & Algodão \\
\hline 16 & Espanha & 0,1 & Milho \\
\hline 17 & México & 0,1 & Algodão, Soja \\
\hline 18 & Colômbia & $<0,1$ & Algodão \\
\hline 19 & Chile & $<0,1$ & Milho, Soja e Canola \\
\hline 20 & Honduras & $<0,1$ & Milho \\
\hline 21 & Portugal & $<0,1$ & Milho \\
\hline 22 & República Tcheca & $<0,1$ & Milho, Batata \\
\hline 23 & Polônia & $<0,1$ & Milho \\
\hline 24 & Egito & $<0,1$ & Milho \\
\hline 25 & Eslováquia & $<0,1$ & Milho \\
\hline 26 & Costa Rica & $<0,1$ & Algodão, Soja \\
\hline 27 & România & $<0,1$ & Milho \\
\hline 28 & Suíça & $<0,1$ & Batata \\
\hline \multirow[t]{2}{*}{29} & Alemanha & $<0,1$ & Batata \\
\hline & TOTAL & 148 & \\
\hline
\end{tabular}

Fonte: JAMES, 2010.

A primeira geração de transgênicos atualmente disponíveis, trouxe benefícios agronômicos aos agricultores, mas nenhum benefício direto para os consumidores. A segunda geração de culturas GMs envolve a saúde e propriedades nutricionais que beneficiam os consumidores, enquanto as culturas de terceira geração visam a produção de alimentos funcionais e produtos farmacêuticos (CELEC et al., 2005; VIJOEN; DAJEE; BOTHA, 2006).

Atualmente, as culturas GMs são desenhadas, ou estão em desenvolvimento, para combater certas deficiências nutricionais, um bom exemplo disso é o "Arroz Dourado", em que a pró-vitamina A é introduzida aos grãos. O objetivo desta modificação é aliviar a deficiência desta vitamina em países em desenvolvimento, onde o arroz é o alimento básico (KOK; KUIPER, 2003).

No presente trabalho, o foco é a soja tolerante ao herbicida glifosato, porém, além de plantas capazes de tolerar a ação de herbicidas, a transgenia introduziu plantas resistentes a 
insetos e pesquisa a tolerância a fungos, bactérias, vírus e estresses abióticos, como a seca; além de produtos com melhor qualidade nutricional, como grãos de soja que produzem óleo com menos gorduras saturadas (NEPOMUCENO, 2011). Pesquisas buscam alcançar avanços na ciência genômica com a descoberta de genes que conferem alterações nas funções metabólicas das culturas e dessa maneira aprimorar o valor nutritivo e conferir maior resistência a estresses abióticos (KÖNIG et al., 2004).

O melhoramento genético de plantas, apesar de parecer uma nova técnica, é utilizada há anos pelo homem para obter espécies de melhor qualidade e rendimento (UZOGARA, 2000). A variação genética que ocorre naturalmente é encontrada em todos os mamíferos, micróbios e plantas. Essas diferenças aleatórias no genoma de um organismo são a base da seleção natural das espécies. Evolução horizontal, transposição, rearranjos de gene, fusão e exclusões são considerados importantes forças evolucionárias (RUEBELT et al., 2006).

Com o advento da biotecnologia moderna, mais especificamente a engenharia genética, tornou-se possível a transferência de um gene específico de um organismo para outro além das fronteiras da espécie, através de um processo de recombinação genética (VILJOEN; DAJEE; BOTHA, 2006). A engenharia genética tem o potencial para produzir variedades melhoradas em termos de características de qualidade e produtividade, mais rapidamente (UZOGARA, 2000). Na década de 80, houve o desenvolvimento da primeira planta transformada pela técnica do DNA recombinante (CELEC et al., 2005).

\subsubsection{Soja tolerante ao herbicida glifosato}

A Companhia Monsanto, nos anos 80, desenvolveu a soja transgênica Roundup Ready®, também conhecida como soja RR (COCKBURN, 2002). A característica desta soja é a tolerância ao herbicida à base de glifosato, que é extensivamente utilizado em todo o mundo em lavouras no período de emergência até a floração do vegetal (MOLDES et al., 2008). Mesmo com o desenvolvimento de outras culturas GMs, a soja corresponde à maior área plantada e produção de GMs no mundo.

A soja RR foi desenvolvida pela inserção de um cassete com o gene cp4, que codifica a enzima 5-enolpiruvilchiquimato-3-fosfato sintase (EPSPS), no genoma da soja (DILL; CAJACOB; PADGETTE, 2008). O cassete cp4 EPSPS deriva de Agrobacterium sp, que é uma bactéria encontrada comumente nos solos. Com a alteração no genoma, onde 
houve mutação e a troca de glicina ao invés de alanina, a planta fica com baixa afinidade pelo herbicida e consegue, através de uma rota metabólica alternativa, dar continuidade à síntese de proteínas e metabólitos secundários para o desenvolvimento da planta (PADGETTE et al., 1995).

O glifosato, comercializado pela Monsanto como Roundup®, pertence à classe dos derivados de glicina, seu nome químico é N-(fosfanometil) glicina (Figura 5).

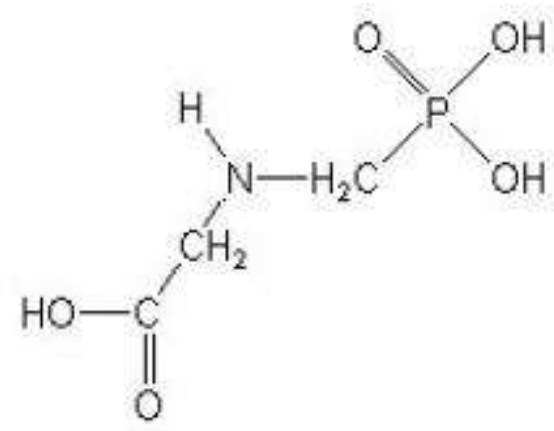

Figura 5: Estrutura química do glifosato.

O glifosato tem um amplo espectro de ação, de aplicação foliar, e age tanto em folhas largas como estreitas (REDDY; ZABLOTOWICZ, 2003; MOLDES et al., 2008). Quanto à questão da toxicidade, é considerado seguro, pois, atua seguindo um caminho metabólico nas plantas (chamado mecanismo do ácido chiquímico), similar ao existente em alguns microrganismos mais complexos, não existindo em animais. O glifosato é um organofosforado, mas se diferencia dos demais por não afetar o sistema nervoso central (AMARANTE-JR et al., 2002). Com relação a sua mobilidade no solo, apresenta movimento pequeno ou ausente em direção da água e teria um efeito residual no solo menor quando comparado com outros herbicidas (REDDY; ZABLOTOWICZ, 2003).

O mecanismo de ação do glifosato se baseia na ligação com o complexo enzimático EPSPS, bloqueando ou diminuindo a atuação biológica da enzima (Figura 6) (BATISTA et al. 2007). Com a inibição da EPSPS, a planta não produz os aminoácidos fenilalanina, tirosina e triptofano e, consequentemente, não consegue sintetizar proteínas e alguns metabólitos secundários. Dessa maneira acumula o chiquimato e causa a morte da planta (HOLT; POWLES; HOLTUM, 1993; AMARANTE-JR et al., 2002; MOLDES et al., 2008). 


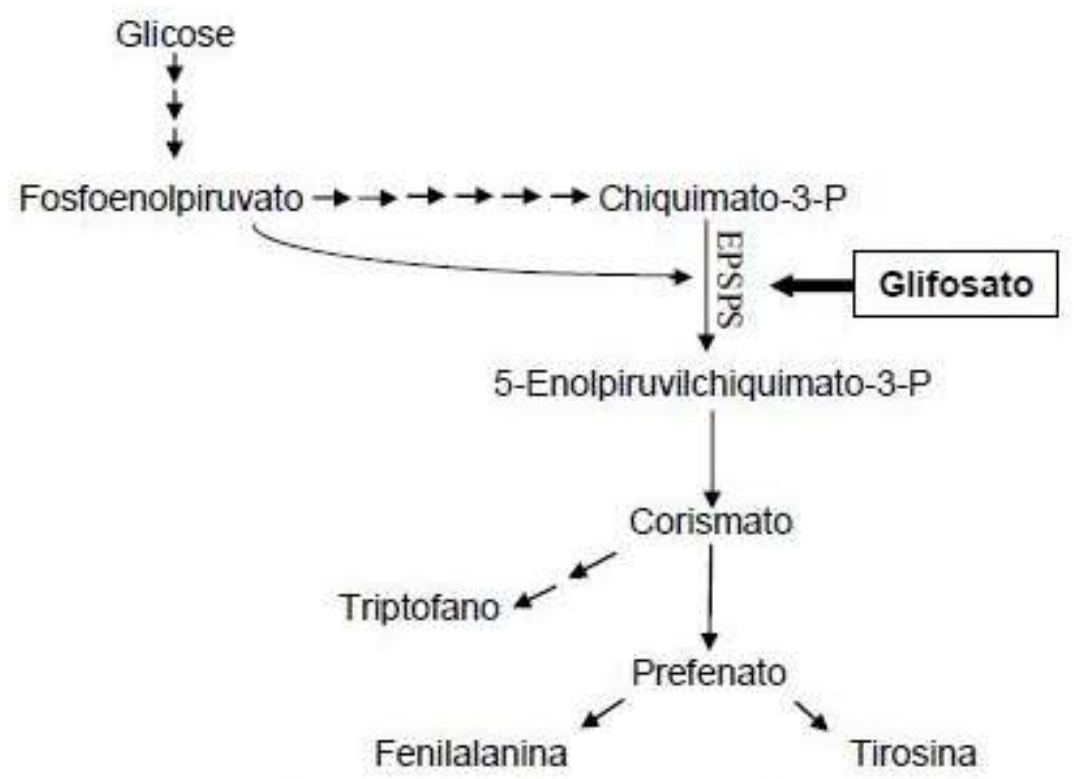

Figura 6: Mecanismo de ação do glifosato sobre a enzima EPSPS, bloqueando ou diminuindo a produção de aminoácidos para o desenvolvimento da planta. Fonte: Tan et al, (2006).

Uma questão interessante é que a tolerância pode se mostrar benéfica porque atua no controle das ervas daninhas, que são organismos considerados destrutivos, pois, disputam com a cultura os mesmos nutrientes. Considerando o valor nutricional do grão, haveria uma menor produção de fatores antinutricionais no vegetal, que são produzidos como mecanismos de defesa da planta, e assim a qualidade nutricional do grão melhoraria.

\subsubsection{Biossegurança da soja geneticamente modificada}

Com o surgimento dos Organismos Geneticamente Modificados (OGMs), questões sobre a segurança ou inocuidade de alimentos derivados de plantas Geneticamente Modificadas (GM) foram levantadas. Tais questionamentos são relativos a possíveis riscos, tanto para a saúde da população que os consome como para o meio ambiente no qual são produzidos. Entre as preocupações sobre a segurança ou inocuidade desses alimentos está a migração de genes de microorganismos usados na transformação, a pleiotropia causada pelos genes exógenos, a disseminação de genes de resistência a antibióticos, a perda do perfil 
nutricional de alimentos básicos da dieta, a introdução de fatores antinutricionais e a incorporação de proteínas tóxicas ou alergênicas (KLETER; PEIJNENBURG, 2003; HUNGERFORD, 2004, BATISTA et al., 2007). Os críticos da tecnologia GM incluem grupos de consumidores preocupados com a saúde, os importadores de grãos da União Européia, agricultores orgânicos, ambientalistas, alguns cientistas, especialistas em ética, grupos de direitos religiosos, políticos, protecionistas comerciais e, sobretudo, formadores de opinião mal informados (UZOGARA, 2000).

Segundo a FAO/WHO, um alimento é considerado seguro se existe uma certeza razoável de que nenhum perigo potencial poderá resultar de seu consumo dentro das condições aceitáveis de seu uso.

Desde 2005, no Brasil o órgão que zela pelo correto manejo dos OGMs é a Comissão Técnica Nacional de Biossegurança - CTNBIO, que é uma instância colegiada multidisciplinar, cuja finalidade é prestar apoio técnico consultivo e assessoramento ao Governo Federal na formulação, atualização e implementação da Política Nacional de Biossegurança relativa a OGMs, bem como no estabelecimento de normas técnicas de segurança e pareceres técnicos referentes à proteção da saúde humana, dos organismos vivos e do meio ambiente, para atividades que envolvam a construção, experimentação, cultivo, manipulação, transporte, comercialização, consumo, armazenamento, liberação e descarte de OGM e derivados (CTNBIO, 2011).

Entre as questões que devem ser levadas em conta, são os efeitos intencionais ou desejados, e efeitos não-intencionais, previsíveis ou não, causados pela inserção de novos genes no DNA da planta ou animal. Considera-se a existência de risco inerente ao processo de modificação genética, ou seja, de ocorrer síntese ou mutação de proteínas que podem ser potencialmente tóxicas e alergênicas, bem como apresentarem ação antinutricional ou mudar o valor nutricional do alimento (LAJOLO; NUTTI, 2003).

Segundo Cockburn (2002), em qualquer transferência de genes, existe o risco potencial de alterar a segurança dos alimentos. Por este motivo, a avaliação da segurança deve incluir uma consideração do potencial de transferência horizontal de genes marcadores de resistência aos antibióticos no intestino de seres humanos ou animais, ou mesmo em solo, e as consequências daí resultantes. Tais preocupações conduziram os desenvolvedores de novos OGMs a substituir estes genes marcadores. 
A identificação dos perigos e caracterização da cultura GM é realizada em quatro etapas:

- $\quad$ Caracterização da cultura-mãe e quaisquer riscos associados a ela;

- Caracterização do processo de transformação e de inserção do DNA recombinante;

- $\quad$ Caracterização da introdução de proteínas e matabólitos;

- Identificação de qualquer outro alvo e alterações inesperadas nas culturas GM, incluindo alterações no metabolismo da planta (KÖNIG et al., 2004).

Formulado pela Organização para Cooperação Econômica e Desenvolvimento (OECD) e desenvolvido pela FAO/WHO, em 1993 foi introduzido o conceito de equivalência substancial que é uma ferramenta para guiar a avaliação de novos OGMs, está baseado na utilização de um produto alimentício tradicionalmente consumido como referência para a comparação com um outro equivalente, porém geneticamente modificado. A aplicação do conceito não é uma avaliação da segurança em si, mas permite a identificação de diferenças potenciais entre os alimentos existentes e o novo produto (KUIPER et al., 2002; RICROCH; BERGE; KUNTZ, 2011).

Para a aplicação do conceito de Equivalência Substancial entre a cultura GM e a cultura convencional reconhecidamente segura são comparadas características morfológicas, agronômicas, químicas e composição, incluindo macro e micro-nutrientes, presença de toxinas e fatores antinutricionais. Significativas mudanças nesses parâmetros deverão ser indicativas de alterações mais profundas nas culturas e precisam ser avaliadas quanto às consequências adversas para a saúde humana (KÖNIG et al. 2004).

Segundo o FDA o princípio da Equivalência Substancial, deriva da avaliação de segurança para consumo humano e animal, concluindo que um produto será "substancialmente equivalente" quando for tão seguro para consumo quanto sua variedade tradicional e ainda quando for idêntico na finalidade de uso, composição nutricional, forma de utilização, manuseio e preparo.

Muitos autores trabalham com o conceito de Equivalência Substancial para avaliar a segurança de um novo alimento GM. Alezandro e colaboradores (2008) avaliaram a composição centesimal e determinaram os teores de isoflavonas, daidzeína e genisteína, da cultivar BRS 243 RR e encontraram valores semelhantes aos da literatura para cultivares convencionais. Mesmo assim, consideraram prudente a realização de testes biológicos, 
toxicológicos e imunológicos mais aprofundados e eficazes para avaliação da segurança quanto ao consumo de alimentos GM. Tais estudos, que avaliem tanto a composição centesimal quanto testes biológicos, toxicológicos e imunológicos de produtos GM em comparação com as suas estirpes genitoras, até o momento ainda não foram realizados.

Kuiper e colaboradores, em 2002, discutiram o uso da equivalência substancial para a avaliação da inocuidade de alimentos derivados de OGMs e consideram uma importante ferramenta, porém recomendaram que outras questões também devessem ser discutidas, como:

- Características dos organismos receptores dos genes e dos processos de modificação genética;

- $\quad$ Expressão e toxicidade das novas proteínas;

- $\quad$ Alterações no metabolismo, incluindo os efeitos secundários da modificação genética;

- $\quad$ Potencial de transferência de genes para a saúde humana;

- $\quad$ Características da alergenicidade potencial do gene recém-inserido;

- $\quad$ Papel dos novos alimentos na dieta.

Os autores (Kuiper et al., 2002) concluíram que o desenvolvimento de perfis em diferentes níveis - genômica, proteômica e metabolômica - deve ser incentivado, para detecção de alterações mais complexas nos novos OGMs.

Kok e colaboradores (2003) sugerem a alteração do termo "Equivalência Substancial" para "Avaliação da Segurança comparativa", considerando que desta forma descreve melhor a natureza comparativa da avaliação. $O$ principio da Equivalência Substancial deve ser considerado apenas uma ferramenta para identificar diferenças potenciais e faz parte de uma abrangente abordagem comparativa de avaliação da segurança, porém, contextualizam que não é uma análise única, de inocuidade e de impacto nutricional nos seres humanos. Portanto, seriam necessários ensaios suplementares toxicológicos e nutricionais (KOK; KUIPER, 2003).

Uma vez que os alimentos derivados de culturas geneticamente modificadas contêm traços de novas proteínas expressas, para a avaliação da segurança deve incluir testes do potencial de alergenicidade da nova cultura em comparação com a cultura tradicional (COCKBURN, 2002). 
Mesmo com tantos estudos, a comercialização dos OGMs em algumas regiões da União Européia, por exemplo, ainda é estritamente regulada. A necessidade de monitorar a presença e verificar a quantidade de OGMs nas culturas agrícolas e produtos derivados tem gerado uma grande demanda de análises capazes de detectar, identificar e quantificar o DNA introduzido ou a(s) proteína(s) expressa(s) em plantas transgênicas (ANKLAM et al., 2002).

Para a rotulagem de alimentos obtidos de organismos geneticamente modificados, há uma norma específica que determina rotulagem especial em gêneros alimentícios que contiverem ingredientes GM acima de 1\% (ANKLAM et al., 2002).

No Brasil, o Decreto 4680/03 é o que regulamenta a rotulagem de OGMs. Aplicase aos alimentos e ingredientes alimentares destinados ao consumo humano ou animal que contenham ingredientes GMs ou foram produzidos a partir de OGMs, com presença acima do limite de $1 \%$ do produto, o consumidor deverá ser informado da natureza transgênica do produto. E ainda determina que os produtos embalados, a granel e in natura deverão ter no rótulo da embalagem, ou do recipiente em que estiverem contidos, o triângulo amarelo contendo $\mathrm{T}$, símbolo de transgênico, e uma das seguintes expressões: "(nome do produto) transgênico", "contém (nome de ingrediente ou ingredientes transgênicos)", ou "produto produzido a partir de (nome do produto) transgênico".

Câmara e colaboradores (2008) discutiram a rotulagem dos OGMs no Brasil e concluíram que vem sendo, ao longo dos últimos anos, objeto de acirradas discussões. O foco da polêmica reside na argumentação de que a alteração nos rótulos para identificar os OGM representaria um acréscimo nos custos do produto, resultante da reformulação exigida para a inclusão do símbolo dos transgênicos ou do aumento físico do rótulo para acomodar tal informação. Além disso, foi levantada a possibilidade de que a inclusão de tal informação provocaria na população uma reação antecipadamente preconceituosa. Alega-se ainda que, do ponto de vista da equivalência substancial, a obrigatoriedade da segregação entre os alimentos transgênicos e os convencionais seria dispensável. Porém, esta última afirmação não tem respaldo técnico-científico (CAMARA et al., 2008). 


\subsection{Alimentos Orgânicos}

Desde o surgimento das culturas GMs, as culturas orgânicas vêm sendo promovidas como alternativa sustentável, saudável e ecológica. Por um lado os agricultores são encorajados a implementar culturas GM justificando a maior produtividade e por outro lado a cultura orgânica é defendida por considerações de ordem sócio-econômicas e ambientais (AZADI; HO, 2011).

A filosofia da agricultura orgânica se baseia num conjunto de processos de produção agrícola, onde os compostos biodegradáveis existentes ou adicionados ao solo, suprimem a demanda mineral e química da planta, desta maneira, havendo menor intervenção humana na natureza e contextualizando essa prática como sustentável (ORMOND et al., 2002).

No Brasil, há o decreto $\mathrm{n}^{\circ} 6.323$, de 27 de dezembro de 2007 que regulamenta a Lei $\mathrm{n}^{\circ}$ 10.831 de dezembro de 2003, que dispõem sobre a agricultura orgânica, e dá outras providências. De acordo com a lei “considera-se sistema orgânico de produção agropecuária todo aquele em que se adotam técnicas específicas, mediante a otimização do uso dos recursos naturais e socioeconômicos disponíveis e o respeito à integridade cultural das comunidades rurais, tendo por objetivo a sustentabilidade econômica e ecológica, a maximização dos benefícios sociais, a minimização da dependência de energia nãorenovável, empregando, sempre que possível, métodos culturais, biológicos e mecânicos, em contraposição ao uso de materiais sintéticos, a eliminação do uso de organismos geneticamente modificados e radiações ionizantes, em qualquer fase do processo de produção, processamento, armazenamento, distribuição e comercialização, e a proteção do meio ambiente."

O aumento da demanda pelos produtos orgânicos deve-se ao uso de defensivos agrícolas nas culturas convencionais e a busca da população por alimentos livres destes produtos (ARBOS et al., 2010 ${ }^{\mathrm{A}}$; SANTOS; MONTEIRO, 2004). Esses insumos nas plantas garantem nutrientes adequados e disponibilidade de água para cultivos, ao mesmo tempo suprimem a presença de organismos concorrentes, como ervas daninhas, insetos e patógenos, a fim de maximizar os rendimentos. Inevitavelmente, sem o controle adequado no uso dos agroquímicos sintéticos, alguns resíduos permanecem nos alimentos podendo criar riscos à saúde (MAGKOS; ARVANITI; ZAMPELAS, 2003). 
Nas culturas orgânicas, é clara a vantagem no custo de produção, referentes aos insumos químicos. Desta forma, os pequenos agricultores, teoricamente com menos recursos, conseguem manter suas plantações. A desvantagem é que sem o uso dos defensivos agrícolas, a plantação terá menor produtividade e seu custo final será maior, tanto para o produtor quando para o consumidor (SUTHERLAND, 2011). O principal obstáculo para a transição da agricultura convencional para a cultura orgânica são os custos maiores por área plantada (AZADI; HO, 2010).

Além da menor produtividade, os custos altos da produção dos orgânicos são atribuídos à falta de recursos e treinamento dos produtores, desorganização no sistema de produção e comercialização, uso de embalagens para distinção dos produtos, valor agregado devido o aspecto ecológico e a necessidade do produtor orgânico ter que pagar pelas certificações, assistências técnicas e fiscalizações (SANTOS; MONTEIRO, 2004).

A pequena adoção dos agricultores da cultura orgânica é justificada por algumas limitações, como o pouco conhecimento e habilidade para reagir a fatores externos imprevisíveis, como a seca, a súbita chegada de novas doenças ou pragas; preconceitos da maioria das estruturas legais em favor da agricultura convencional (AZADI; HO, 2010).

Yiridoe e colaboradores (2005) realizaram um estudo de comparação das percepções e preferências dos consumidores de orgânicos versus alimentos convencionais e percebeu as seguintes características: a busca pelos alimentos orgânicos esta baseada nos conhecimentos e na relação destes com um conjunto de características do bem. Estas características não são notadas no ato de compra ou uso, para detectá-las são necessárias certificações e informações. Entre estas características positivas que os consumidores de orgânicos apreciam está saúde humana, segurança do alimento e gestão ambiental, entre outras características de produto, tais como valor nutritivo, sabor, frescor, aparência, etc. Não houve correlações entre a renda, nem entre a idade com o comportamento de compra de orgânicos (YIRIDOE; BONTIANKOMAH; MARTIN, 2005).

Os produtos orgânicos recebem selos que certificam sua procedência. Estes selos são distribuídos pelas certificadoras, que são responsáveis pela garantia da qualidade e rastreabilidade destes produtos. No Brasil, as certificadoras são credenciadas junto ao Colegiado Nacional para a Produção Orgânica (CNPOrg), que é vinculado à Secretaria de Defesa Agropecuária do Ministério da Agricultura, Pecuária e Abastecimento. O agricultor para se tornar um produtor orgânico, tem a necessidade de conformidade com as diretrizes estipuladas pela certificadora, como qualidade de água, não uso de agrotóxicos e adubos químicos, e são submetidos a inspeções periódicas (SANTOS; MONTEIRO, 2004). 
Arbos e colaboradores $\left(2010^{\mathrm{B}}\right)$ avaliaram a qualidade sanitária de hortaliças orgânicas no que se refere à contaminação microbiológica, baseado em trabalhos que apontam que a prática do sistema orgânico, como uso de esterco animal e proibição do uso de agrotóxicos possa aumentar a contaminação microbiológica e parasitaria, tornando o alimento inadequado ao consumo (STEPHENSON, 1997). Nos resultados de Arbos $\left(2010^{\mathrm{B}}\right)$, tanto para as amostras de alface quanto cenouras orgânicas, foram detectadas coliformes de origem fecal e Salmonella sp. em valores superiores aos permitidos pela legislação brasileira, e também houve a presença de estruturas parasitárias.

O mesmo grupo de pesquisadores avaliou os teores de compostos fenólicos e a atividade antioxidante de hortaliças orgânicas (rúcula, almeirão e alface) em comparação com as mesmas hortaliças convencionais. Os teores de fenólicos totais foram significativamente maiores nos vegetais orgânicos sugerindo o benefício do consumo dessas hortaliças cultivadas deste modo (ARBOS et al., 2010 ${ }^{\mathrm{A}}$ ).

Dangour e seus colaboradores (2009) realizaram uma revisão sistemática sobre a qualidade nutricional dos alimentos orgânicos em comparação com os alimentos convencionais. Nessa revisão foram avaliados os artigos publicados dos últimos 50 anos (1958 - 2008) e, segundo seus parâmetros, excluíram os trabalhos que não apresentavam qualidade satisfatória. Conforme os resultados, em 10 das 13 categorias de nutrientes analisados, não houve diferenças significativas atribuídas aos métodos de produção. As diferenças que foram detectadas entre as culturas eram biologicamente plausíveis e foram provavelmente devido às diferenças de uso de fertilizantes (nitrogênio e fósforo) e maturação na colheita (DANGOUR et al., 2009).

Um recente estudo da Bélgica avaliou o consumo de vegetais orgânicos versus convencionais sobre o aspecto de ingestão de nutrientes e contaminantes. Apenas na detecção de nitrato, de 1 a $4 \%$ dos consumidores de alface orgânica excederam a dose diária tolerável preconizada pelos órgãos de saúde, que já haviam observado a questão do nitrato e concluíram que os efeitos benéficos de consumir legumes e frutas superam o risco potencial para a saúde de humanos decorrentes da exposição ao nitrato. Nos demais resultados do estudo não houve diferenças significativas entre orgânicos e convencionais. Eles salientam também que os consumidores orgânicos podem consumir mais alface que os demais consumidores e desta forma, naturalmente ingerem mais nitrato. Pelos resultados obtidos, acreditam que os benefícios à saúde devem ser reforçados para a população em geral independente do sistema agrícola pelo qual foi produzido (HOEFKENS et al., 2010). 
Se o agricultor trabalhar dentro do limite seguro do uso dos insumos agrícolas e o consumidor ter hábitos corretos de higienização, os riscos associados a contaminantes de alimentos podem ser minimizados, independentemente da origem orgânica ou convencional do alimento (MANGKOS et al., 2003).

$\mathrm{Na}$ literatura acadêmica existe um grande número de trabalhos publicados relacionando os aspectos nutricionais dos alimentos orgânicos e convencionais, porém os resultados são bastante divergentes. Lima e seus colaboradores (2011) fizeram recentemente um amplo levantamento e concluíram que são necessários mais e melhores estudos para determinar tais diferenças, tomando cuidado com fatores que naturalmente alteram a qualidade nutricional de um alimento, como clima, características de solo, processos de preparação de alimento, etc. A partir do levantamento, julgaram que os alimentos orgânicos não apresentam comprovadamente teores mais altos de nutrientes, mas sim um menor conteúdo de pesticidas e substancias nocivas à saúde. Mas salientam que é preciso relativizar este dado, pois, sem os pesticidas, seria necessário muito mais mão de obra e terras para atingir o alto rendimento atualmente alcançado pelo uso deles, ainda mais quando consideramos o alto nível de pessoas famintas no mundo (LIMA; VIANELLO, 2011).

As plantas têm mecanismos endógenos de defesa que resultam na produção de toxinas, que por sua vez servem para protegê-las contra predadores em situações de perigo ou stress. Com a eliminação de agroquímicos sintéticos, naturalmente aumenta a população de insetos e outras biotas causadoras de males e danos, ou ervas daninhas concorrentes pelos insumos da planta cultivada. Embora claramente benéficas para o ambiente e a biodiversidade do ecossistema, podem servir como fontes adicionais de estresse para as plantas e, portanto, são causas complementares para produção de toxinas endógenas (MAGKOS; ARVANITI; ZAMPELAS, 2003).

Frente a isso, é possível argumentar que a produção de toxinas naturais é reprimida na presença de produtos químicos sintéticos, enquanto é induzida na ausência deles, a fim de manter a integridade defensiva da planta (MAGKOS; ARVANITI; ZAMPELAS, 2003). Estudos de qualidade sobre os riscos associados à saúde, referente aos defensivos endógenos, ou até a comparação entre as concentrações dos mesmos em culturas orgânicas, convencionais e GM não são encontrados na literatura. 


\subsection{Análise proteômica}

O sufixo "omica" é atualmente usado para abranger as novas técnicas de pesquisa que compreendem a genômica, transcriptômica, proteômica e metabolômica. Assemelham-se pelo objetivo comum de isolar e caracterizar distintas biomoléculas. Na década de 90 houve o boom da genômica, que consiste em estudos dos genes e suas funções. Consequentemente, intensificaram-se as pesquisas de expressão gênica: através de RNA mensageiro, pela transcriptômica, e de proteínas, pela proteômica. A metabolômica é responsável pela investigação dos metabolitos secundários que interagem diretamente com as proteínas e/ou outras moléculas.

As "omicas" vêm se destacando como ferramentas atuais para a avaliação da segurança de alimentos. A metabolômica e a proteômica tem sido usadas em estudos comparativos entre alimentos geneticamente modificados e convencionais a fim de elucidar questões sobre biossegurança e alterações nos perfis protéicos ou de metabólitos secundários (RICROCH; BERGE; KUNTZ, 2011).

García-Villalba e seus colaboradores (2008) realizaram um estudo metabolômico comparativo entre cultivares transgênicas e não transgênicas de soja cultivadas em condições idênticas, com o uso de eletroforese capilar e espectrometria de massas. Objetivaram identificar e quantificar os principais metabólitos encontrados nessas duas linhagens e possível seleção de metabólitos para uso como biomarcadores de soja transgênica. Em geral, os mesmos metabólitos e em quantidades semelhantes foram encontrados nas duas variedades.

A proteômica esta mais difundida para este tipo de estudos comparativos, e vários grupos de diversos países trabalham com análises proteômicas de diferentes alimentos. Natarajan e seus colaboradores $\left(2005,2006,2007^{\mathrm{A}}, 2007^{\mathrm{B}}\right)$ já realizaram extensivos trabalhos comparativos com soja, sob diferentes enfoques, ora, ensaios comparativos entre proteínas de reserva (NATARAJAN et al., 2006), ora, ensaios adaptativos para a padronização da técnica para uso com a soja (NATARAJAN et al., 2005), que posteriormente foi seguido por demais pesquisadores da soja, inclusive no presente trabalho.

A proteômica é uma ferramenta poderosa para a separação de um complexo de proteínas e se torna uma parte importante da estratégia da genômica funcional (ZHEN et al., 2007). Apesar de ser uma ferramenta atual, já vem influenciando vários aspectos da cadeia 
produtiva alimentar (agricultura, produção de alimentos, segurança alimentar e garantia da qualidade) (MAMONE et al., 2009)

O uso da proteômica é bastante amplo, como: utilização da técnica para a detecção e investigação de possível contaminação bacteriana em frutos do mar (PIÑEIRO et al., 2003); pesquisa do uso de anabolizantes em carnes e produtos lácteos (DUMAS et al., 2005); identificação de possíveis candidatos e marcadores de qualidade para a conversão post mortem do músculo da carne suína durante armazenamento (LAMETSCH; BENDIXEN, 2001).

Inicialmente o uso da proteômica para fins biotecnológicos era bastante restrito, porém nos últimos anos seu uso tornou-se rotineiro em indústrias, no desenvolvimento, validação e otimização de processos que envolvem biotecnologia. A proteômica também pode ser usada para validação e controle de processos industriais de alimentos (GASO-SOKAC; KOVAC; JOSIC, 2010).

Os dois passos principais para a proteômica clássica são a separação de proteínas e sua posterior identificação. Para isso, a eletroforese bi-dimensional em gel de poliacrilamida (2D-PAGE) e espectrometria de massas (MS) são combinados (XU et al., 2006). A união destas duas técnicas pode monitorar, em mapas protéicos ou componentes isolados de amostras muito complexas, a presença ou ausência ou nível de expressão de proteínas específicas (MAMONE et al., 2009).

Gorg et al. 2004 avaliaram a tecnologia atual da eletroforese bidimensional para a proteômica e concluíram que mesmo com muitas plataformas proteômicas emergentes, ainda não há método que substitua as ferramentas 2D juntamente com MS para separar, identificar complexos de misturas de proteínas e ainda gerar mapas de proteínas intactas, refletindo as mudanças nos níveis de expressão das proteínas, ou isoformas pós-traducionais.

Nas culturas GMs, fragmentos de DNA exógeno podem ser inseridos no genoma do organismo hospedeiro, principalmente nos vegetais a fim de melhorar a produtividade, a tolerância a herbicidas ou induzir a produção de novas substâncias não presentes anteriormente. Porém, alterações inesperadas podem acontecer, e para monitorar tais mudanças, a proteômica tem atuado como uma ferramenta eficiente para a comparação das culturas GM e não GM (GASO-SOKAC; KOVAC; JOSIC, 2010).

As proteínas são responsáveis por muitas reações alérgicas, razão pela qual a proteômica é amplamente utilizada na investigação para a identificação e quantificação de alérgenos (GASO-SOKAC; KOVAC; JOSIC, 2010). Como a soja está dentro do grupo dos 8 alimentos mais alergênicos, grupo este que compreende $90 \%$ de todas reações alérgicas 
(ZARKARDAS et al, 1999; L'HOCINE; BOYE; JOUVE, 2007), muitos estudos avaliam as possíveis alterações em função do seu perfil alergênico quando submetida a transgenia (BATISTA et al., 2007).

O emprego de sementes de soja para estudos proteômicos é de grande valia porque o grão apresenta grandes quantidades de proteínas em sua composição (cerca de 40\%). O uso das ferramentas 2D-PAGE associado a MS tem sido extensivamente usado para examinar a composição natural e perfis de proteínas de soja transgênica e determinar qualidade de sementes de soja (NATARAJAN et al., 2007 ${ }^{\mathrm{B}}$ ).

Vale destacar que a proteômica pode ser dividida em estrutural que compara a expressão protéica em distintas condições e funcional, na qual se estudam as atividades biológicas das proteínas (ANDERSON; MATHESON; STEINER, 2000). Além disso, o uso da bioinformática aliada a proteômica vem trazendo avanços na busca de novos alvos terapêuticos e compreensão de mecanismos de doenças até então desconhecidos (SRIYAM et al., 2007).

\subsubsection{Eletroforese Bidimensional}

O’Farrel e Klose em 1975 desenvolveram a técnica de eletroforese 2D, eles objetivaram a análise das proteínas de Escherichia coli. Como a técnica apresentou relativa sensibilidade e reprodutibilidade, pesquisadores iniciaram a formação de bancos de dados de proteínas (O’FARREL, 1975; KLOSE, 1975).

A eletroforese bidimensional tem sido, e continua sendo para muitas espécies de plantas, uma das técnicas mais utilizadas para a separação de proteínas em experimentos de proteômica. A técnica é de fácil manuseio e apresenta custo-eficiência satisfatório, tornandose escolha para a maioria dos estudos comparativos (VALLEDOR; JORRIN, 2011).

A principal vantagem da eletroforese bidimensional é sua alta resolução em separações analíticas de misturas complexas de proteínas (ZARKADAS et al., 2007) de acordo com ponto isoelétrico, peso molecular, solubilidade e abundância relativa (GÖRG; WEISS; DUNN, 2004). A técnica se diferencia da eletroforese unidimensional por ter a etapa extra de separação pelo ponto isoelétrico e desta maneira, forma um mapa protéico muito mais detalhado e informativo, estabelecendo na prática uma identidade para cada espécie analisada. 
Na primeira etapa leva-se em conta a carga das proteínas que se separam pela formação de um campo elétrico, que se dá pela focalização isoelétrica (IEF PAGE). No pI, com as cargas em equilíbrio, as proteínas param de migrar pelo gel com gradiente de $\mathrm{pH}$ (GÖRG; WEISS; DUNN, 2004).

Na segunda dimensão, o deslocamento ocorre em função da massa molecular das proteínas em condição desnaturante, ou seja, presença de dodecil sulfato de sódio (SDS) que serve para eliminar as cargas das proteínas. $O$ detergente tem a função de desnaturar as proteínas, fazendo que elas mudem suas configurações que geralmente é globular, para uma estrutura linear e dessa maneira, sem o interferente de estrutura tridimensional das proteínas, todas irão reagir da mesma maneira na rede do gel formada rotineiramente por poliacrilamida (GÖRG; WEISS; DUNN, 2004).

Para intensificar a alta resolução da eletroforese 2D, a extração das proteínas pode ser realizada com ácido tricloroacético e acetona, que são úteis para minimizar a degradação protéica devido a presença de proteases e também ajudam na remoção de compostos interferentes como lipídios, pigmentos, polifenóis, entre outros (ZARKADAS et al., 2007; GÖRG; WEISS; DUNN, 2004).

Portanto, a eletroforese $2 \mathrm{D}$ resulta da combinação de 2 técnicas: a etapa de IEF PAGE seguida da etapa SDS PAGE (O'FARREL, 1975; GÖRG; WEISS; DUNN, 2004). Géis contendo numerosos spots, em geral, bem definidos e separados podem ser obtidos. Cada spot corresponde uma proteína ou forma protéica.

Dependendo do tamanho do gel e do gradiente de $\mathrm{pH}$ utilizado, a eletroforese 2D pode detectar mais de 5000 proteínas simultaneamente (GÖRG; WEISS; DUNN et al. 2004).

A análise de imagens dos géis bidimensionais é um passo crucial no fluxo de trabalho com proteômica e tem impacto direto sobre a obtenção de dados qualitativos e quantitativos. Como a análise é um processo complexo e gera grandes quantidades de dados, é necessária a utilização de um software (STESSL; NOE; LACHMANN, 2009). Com a análise das imagens é possível obter os resultados relativos à comparação entre os géis. Essa etapa consiste em um trabalho minucioso do manipulador para a detecção de alterações inerentes à técnica, diferenças de colorações, concentração relativa de cada spot, etc.

A limitação da eletroforese 2D é o número alto de replicatas que é necessário realizar para conseguir uma boa reprodutibilidade, pois a técnica apresenta muitos interferentes como a própria manipulação e a variabilidade intrínseca das amostras biológicas (ERAVCI et al., 2007). Outras dificuldades citadas da técnica são as proteínas com extremos de MM e pI ou em baixas concentrações (YE et al., 2007). 


\subsubsection{Espectrometria de massas}

A maioria dos alimentos é produzida a partir de organismos vivos e tecidos, refletindo a complexidade dos sistemas dos quais derivam. Os processos tecnológicos utilizados na preparação dos produtos alimentares contribuem ainda mais para melhorar a heterogeneidade dos sistemas protéicos através da indução de inúmeras reações químicas, tais como complexação com outros componentes e proteólise, entre outros. Nos sistemas biológicos ainda existem as variações protéicas em função do ambiente, tempo e estado fisiológico do organismo de origem. Toda essa complexidade dificulta a caracterização completa de proteomas de alimentos (MAMONE et al., 2009).

Com a eletroforese bi-dimensional é possível determinar pesos moleculares e pontos isoelétricos aproximados das frações das proteínas analisadas através da posição do spot no gel, e desta maneira supor a identidade desta proteína ou fração. Porém, esses dados não são totalmente precisos pelo número de variáveis que a eletroforese $2 \mathrm{D}$ apresenta. Para uma identificação precisa, lança-se mão da espectrometria de massas. Esta é uma técnica analítica poderosa, utilizada para identificar e quantificar compostos, elucidar propriedades químicas e estruturais de moléculas. Apresenta alta sensibilidade e permite mensurar proteínas e peptídeos em fentomoles (CONCEIÇÃO; MOREIRA; BINSFELD., 2006).

Atualmente, a espectrometria de massas (MS) é a principal metodologia para a caracterização de peptídeos e proteínas nas pesquisas com matérias primas alimentares (MAMONE et al., 2009). A técnica vem se destacando por ser de altíssima sensibilidade e por gerar um grande número de resultados com muita qualidade, precisão e resolução (CAREY; MITNIK, 2002; XU et al., 2006).

Para identificar possíveis efeitos intencionais ou indesejados devido à modificação genética nas culturas GMs, pode-se fazer uso associados das "omicas" e MS, desta forma é possível identificar a expressão biomolecular de compostos específicos que representam peças chaves das vias metabólicas importantes na planta como macro e micronutrientes, alérgenos conhecidos, fatores anti-nutricionais e toxinas. A diferença nos traços de expressão de tais biomoléculas deve ser avaliada em relação ao seu impacto sobre meio ambiente, segurança para os seres humanos e animais e qualidade nutricional (MAMONE et al., 2009).

Inúmeros estudos têm utilizado MS para avaliar diferentes compostos em alimentos, inclusive na soja que é o foco deste trabalho, destacando alterações relativas às 
modificações genéticas, desenvolvimento da planta ou até mesmo quando submetidos a condições extremas de processamento.

$\mathrm{Na}$ tentativa de detectar efeitos colaterais não intencionais durante manipulações genéticas do milho (evento MON 810) por bombardeio, Zolla e seus colaboradores (2007) utilizaram 2D/MS para comparar os perfis proteômicos da variedade transgênica e duas gerações subsequentes, com seus respectivos controles isogênicos. Pequenas alterações foram percebidas, e as justificaram pelos naturais rearranjos cromossômicos e recombinações genéticas (ZOLLA et al., 2007).

Foi possível diferenciar as proteínas de arroz da diferentes via metabólicas, quando Koller e seus colaboradores comparam por 2D/MS as proteínas de folhas, raízes e tecidos das sementes. Por meio da espectrometria de massas, conseguiram indicar que as enzimas envolvidas em vias metabólicas centrais estão presentes em todos os tecidos, enquanto que enzimas de especialização são encontradas em tecidos específicos (KOLLER et al., 2002).

A técnica da espectrometria de massas baseia-se em 4 etapas distintas: ionização da molécula; separação dos íons gerados; conversão dos feixe de íons em sinal elétrico; e finalmente a medida dos íons.

$\mathrm{Na}$ fase de ionização, as moléculas da amostra são convertidas em íon de fase gasosa. Existem dois processos de ionização capazes de gerar íons a partir de proteínas e peptídeos. Estes dois processos são conhecidos como ionização por dissociação da matriz mediada por Laser (MALDI- matrix assisted laser desorption ionization) e por pulverização de elétrons em micro-capilares sob pressão atmosférica e alta voltagem (ESI - electron spray ionization). Os dois processos são suaves e mantêm inclusive ligações fracas (MANN; HENDRICKSON; PANDEY, 2001).

O processo Electrospray (ESI) consiste em um spray com gotículas carregadas formadas pela diferença de potencial entre um tubo capilar e um eletrodo cilíndrico que circunda a saída do capilar. Posteriormente as gotículas passam através de um gás secante e as partículas carregadas tornam-se cada vez menores e são ejetadas para a fase gasosa (GALDOS-RIVEROS et al., 2010).

A segunda etapa consiste na separação dos íons segundo suas cargas previamente geradas de acordo com a razão massa/carga $(\mathrm{m} / \mathrm{z})$. O analisador de massas do tipo TOF (Time-of-Flight) se baseia na aceleração das partículas e na relação do tempo necessário para atingir o detector (JAMES, 1997). 
A conversão do feixe de íons em sinal elétrico se dá por um transdutor. A última etapa encarrega-se da medida da abundância dos íons, ou seja o cálculo da altura ou área dos picos formados.

Graças aos progressos da bioinformática, que permitem gerir e armazenar bancos de dados obtidos pela genômica e proteômica, houve um significativo avanço no estudo das proteínas (MAMONE et al., 2009). A finalização do processo consiste na interpretação dos espectros gerados pelos espectrômetros de massas que é realizado por consultas a bancos de dados (XU et al., 2006) como SEQUEST e MASCOT.

No MASCOT, software de identificação das proteínas e peptídeos, a proteína ao ser identificada, recebe uma pontuação (score), além de informações como o número de acesso no banco de dados (NCBI), massa molecular, ponto isoelétrico e cobertura de sequência dos espectros de massas. 


\section{OBJETIVOS}

\subsection{Geral}

Análise proteômica comparativa entre amostras de soja (Glycine max) convencionais e GMs.

\subsection{Específico}

- Detectar alterações de expressão protéica entre amostras da mesma espécie vegetal com a utilização da técnica de eletroforese bidimensional e identificar a presença de proteínas heterólogas bem como de possíveis alterações na composição peptídica de variedades convencionais e GM;

- Identificar por espectrometria de massas os componentes protéicos que se destacam no mapa de variedades convencionais e GM, com enfoque para os fatores antinutricionais e lipoxigenases.

- Comparar os perfis protéicos entre amostras convencionais e GMs contrapondo-se ao mapa protéico de variedades orgânicas. 


\section{MATERIAL E MÉTODOS}

\subsection{Material vegetal}

As amostras de soja (Glycine max) convencionais e geneticamente modificadas tolerante ao herbicida glifosato foram fornecidas pela Embrapa Soja Londrina - PR. São amostras cultivadas em paralelo, ou seja, convencional ao lado de sua respectiva GM, com distanciamento recomendado para não haver contaminações cruzadas entre as distintas linhagens.

Recebemos um total de oito amostras, entre elas, três variedades parentais denominadas: BRS 133, BRS 134, BRS 137, três correspondentes GM denominadas: BRS RR 245, BRS RR 247, BRS RR 255 que foram cultivadas em 2009. E ainda duas amostras orgânicas, sendo que uma delas é comercial (Vmax - Syngenta) e outra ainda encontra-se nos campos de pesquisa (BRS 232), foram denominadas no nosso laboratório como 1 e 2 orgânica, respectivamente.

Tabela 2: Variedades de soja recebidas pela Embrapa - Soja e denominação recebida em nosso laboratório.

\begin{tabular}{cc}
\hline Amostras de Sojas Convencionais & Amostras de Sojas GM \\
\hline BRS 133 - Amostra 1 & BRS RR 245 - Amostra 2 \\
\hline BRS 134 - Amostra 3 & BRS RR 247 - Amostra 4 \\
\hline BRS 137 - Amostra 5 & BRS RR 255 - Amostra 6
\end{tabular}

A indicação de regiões de cultivo das seis linhagens de soja fornecidas são os estados do Paraná, Santa Catarina, Rio Grande do Sul, São Paulo e sul do estado do Mato Grosso do Sul. Os principais tipos de resistência que as amostras apresentam são: Cancro da haste, Mancha "olho de rã", Mosaico comum da soja e Vírus da necrose da haste (EMBRAPA, 2011).

O transporte das amostras ocorreu dentro do preconizado pela lei vigente. A manipulação das amostras GM foi realizada conforme as recomendações da CTNBio, em observância especial da Instrução Normativa $n^{\circ} 7$. Os grãos e sementes foram devidamente embalados, etiquetados e armazenados a $-20^{\circ} \mathrm{C}$ antes do uso para extração das proteínas. 
O presente trabalho foi aprovado pela Comissão Interna de Biossegurança (CIBio) da Faculdade de Ciências Farmacêuticas e o laboratório Biotecnologia de Alimentos é credenciado junto à CTNBio para trabalhos com OGM de classe de risco I (CQB 098).

\subsection{Preparo das amostras}

Para obtenção de amostragens representativas dos lotes de soja fornecidos, utilizou-se o método de quartejamento conforme normas ABNT (BRASIL, 1991). O quartejamento consiste na distribuição de toda amostra em uma superfície e divisão da mesma em quatro partes, sendo que duas partes diagonais são eliminadas. Com o restante, repete-se o processo até obter uma quantidade que represente 5-10\% do todo.

Este procedimento foi realizado três vezes para cada amostra, para obtenção das triplicatas. Posteriormente, de cada triplicata realizou-se a análise proteômica em triplicata, para garantir a reprodutibilidade entre as amostras e também entre as triplicatas. Na Figura 7 pode-se observar o delineamento experimental para amostra 1, e que foi praticado em todas as amostras.

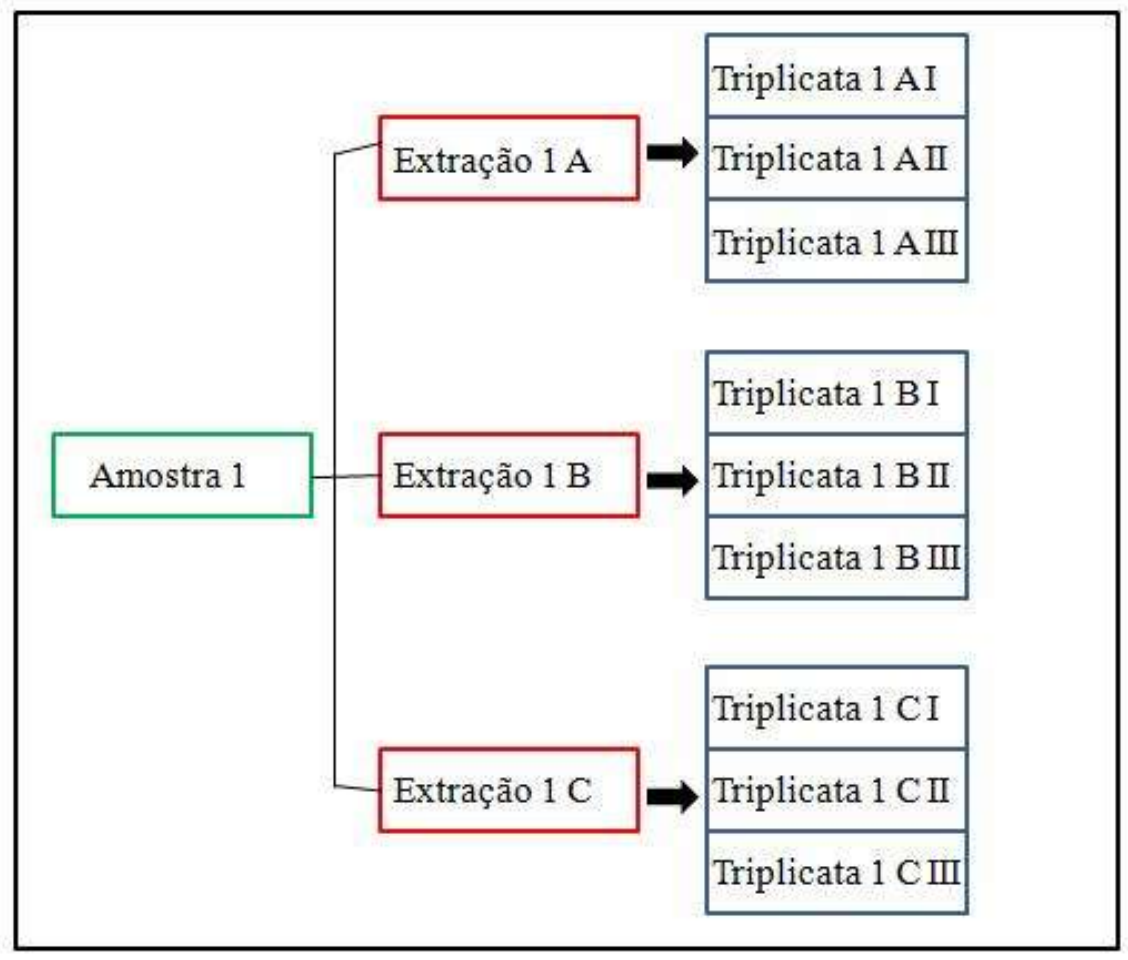

Figura 7: Delineamento experimental da amostra 1, e que corresponde ao realizado para as demais amostras. 
Além da análise minuciosa dos mapas protéicos das amostras convencionai e GMs em pH de 3-10, realizaram-se análises adicionais em $\mathrm{pH}$ de 4-7, que além de facilitar a extração dos spots para a identificação de proteínas por espectrometria de massas, colabora na elucidação de questões relativas à expressão de proteínas que no $\mathrm{pH}$ 3-10 ficariam próximas, sobrepostas ou ocultas.

\subsection{Extração e quantificação de proteínas}

As sementes inteiras de cada amostra $(5 \mathrm{~g})$ foram congeladas em nitrogênio líquido e trituradas em almofariz. As amostras trituradas foram submetidas à extração protéica pelo método que utiliza ácido tricloroacético (TCA) e acetona para precipitação e uréia para solubilização. O protocolo adotado foi avaliado e descrito por Natarajan e colaboradores (2005).

Para realização da extração de proteínas por este método, aproximadamente 100 $\mathrm{mg}$ de amostra triturada foram homogeneizadas com $5 \mathrm{ml}$ de solução contendo $(10 \%(\mathrm{p} / \mathrm{v})$ de TCA em acetona com $0,07 \%$ (v/v) de 2-mercaptoetanol), a proteína total foi precipitada durante a noite a $-20^{\circ} \mathrm{C}$. $\mathrm{O}$ extrato foi centrifugado a $20.800 \mathrm{X} \mathrm{g}$ por $20 \mathrm{~min}$ a $4^{\circ} \mathrm{C}$, em seguida o pellet obtido foi lavado três vezes com acetona contendo $0,07 \%(\mathrm{v} / \mathrm{v})$ de 2mercaptoetanol. O resíduo obtido foi seco à temperatura ambiente por $1 \mathrm{~h}$, após a evaporação da acetona, a amostra foi ressuspensa em $1 \mathrm{ml}$ de tampão de lise [9 M uréia, 4\% (p/v) CHAPS, 2\% (v/v) de anfólitos (pH 3-10 e 4-7) e 40mM ditiotreitol (DTT)], seguida por sonicação em gelo por 30 min. O material insolúvel foi removido por centrifugação a 20.800 $\mathrm{X} g$ por $20 \mathrm{~min}$ a $4^{\circ} \mathrm{C}$ e o sobrenadante transferido para um novo tubo.

A quantificação de proteínas foi realizada pelo método de Bradford (Bradford,1976), no qual a proteína solúvel se liga ao reagente por meio de ligações hidrofóbicas formando uma coloração azul, com absorbância determinada a $\lambda=595 \mathrm{~nm}$.

As concentrações das proteínas foram calculadas através da interpolação dos valores obtidos com uma curva padrão de albumina sérica bovina. As amostras foram armazenadas a $-20^{\circ} \mathrm{C}$ até o momento de uso. 


\subsection{Eletroforese unidimensional}

As etapas de obtenção de extratos protéicos foram acompanhadas por eletroforese em gel de poliacrilamida contendo dodecil sulfato de sódio (SDS-PAGE), segundo Laemmli (1970), em géis com 12\% de acrilamida e corrida eletroforética cuba modelo Mini Protean (BIO-RAD), com a utilização de tampão $25 \mathrm{mM}$ de Tris base, $192 \mathrm{mM}$ de glicina e $0,1 \%$ $(\mathrm{p} / \mathrm{v})$ de SDS.

Para cada amostra utilizou-se a massa estimada de $30 \mu \mathrm{g}$ de proteínas. A revelação foi feita com corante Coomassie coloidal.

\subsection{Eletroforese bidimensional}

\subsubsection{Focalização isoelétrica}

As tiras de focalização isoelética, IPG (immobilized $\mathrm{pH} \mathrm{gel}$ ), foram reidratadas durante $20 \mathrm{~h}$ à temperatura ambiente no aparato adequado, utilizando alíquotas de $200 \mu \mathrm{g}$ de proteínas dissolvidos em $250 \mu \mathrm{l}$ de tampão (8 M uréia, 2\% de CHAPS, 0,5\% (v/v) de anfólitos (pH 3-10 e 4-7), 20 mM DTT e 0,005\% (p/v) azul de bromofenol), sendo o DTT adicionado imediatamente antes do uso. Sobre as tiras de IPG acrescentaram-se cerca de $3 \mathrm{ml}$ de óleo mineral para evitar a evaporação e ressecamento dos reagentes durante a reidratação.

Na primeira dimensão da eletroforese 2D as proteínas foram separadas de acordo com seu ponto isoelétrico (pI), através do processo de focalização isoelétrica (IEF), utilizando o sistema Ettan IPGphor III - GE Healthcare. A caracterização das proteínas presentes na amostra foi realizada usando tiras de $13 \mathrm{~cm}$, com gradiente de $\mathrm{pH}$ de 3-10 e pH de 4-7. A focalização isoelétrica foi realizada nas condições de temperatura, voltagem e tempo, de acordo com as recomendações do fabricante. Após a focalização isoelétrica, as tiras foram removidas do equipamento e armazenadas a $-20{ }^{\circ} \mathrm{C}$ até a realização da segunda dimensão da eletroforese. 


\subsubsection{Eletroforese SDS-Page}

Para a segunda dimensão primeiramente realizou-se a etapa de equilíbrio das tiras, na qual foram encubadas as tiras de IPG à temperatura ambiente por 15 min em solução redutora de equilíbrio (50 mM Tris- $\mathrm{HCl}, \mathrm{pH} \mathrm{8,8,6} \mathrm{M}$ uréia, 30\% glicerol, 2\% SDS, 0,002\% azul de bromofenol e 1\% de DTT); em seguida foram lavadas com água destilada e mantidas por 15 min em solução de alquilação (50 mM Tris- $\mathrm{HCl}$, pH 8,8, $6 \mathrm{M}$ uréia, 30\% glicerol, 2\% SDS, $0,002 \%$ azul de bromofenol e $2,5 \%$ de iodoacetamida).

Executou-se a segunda dimensão da eletroforese em gel vertical homogêneo de $12 \%$ de acrilamida, nas dimensões: $150 \times 150 \times 1,5 \mathrm{~mm}$, conforme descrito por Laemmli (1970). Depois do equilíbrio das tiras, as mesmas foram inseridas no topo do gel de acrilamida e fixadas com uma solução de agarose $0,5 \%(\mathrm{p} / \mathrm{v})$ solubilizada em tampão de corrida (25 mM Tris-HCl, $192 \mathrm{mM}$ Glicina e 0,1\% (p/v) SDS).

Um padrão de peso molecular (GE Healthcare) foi empregado em cada gel para determinar as massas moleculares aparentes das proteínas. A separação eletroforética das proteínas ocorreu a $20^{\circ} \mathrm{C}$ usando o sistema SE600 (GE Healthcare). No primeiro estágio utiliza-se uma corrente fixa de $15 \mathrm{~mA}$ por gel durante $30 \mathrm{~min}$ e no segundo estágio uma corrente fixa de $45 \mathrm{~mA}$ por gel durante aproximadamente $6 \mathrm{~h}$ com uma voltagem constante de 600 V. Após a eletroforese, os géis são corados.

\subsubsection{Detecção de proteínas}

Para a visualização das proteínas isoladas, coraram-se os géis de poliacrilamida com Coomassie Brilliant Blue G250, segundo o protocolo de Candiano e colaboradores (2004), adaptado em nosso laboratório. As soluções são preparadas imediatamente antes do uso, conforme descrito a seguir. Os géis são submetidos por $60 \mathrm{~min}$ em solução fixadora (40\% (v/v) etanol, $10 \%$ (v/v) ácido acético); lavados duas vezes com água destilada deionizada por 10 min e mantidos por $12 \mathrm{~h}$ em solução de coloração $(0,1 \%$ (p/v) Coomassie Brilliant Blue G250, $2 \%$ (v/v) ácido orto-fosfórico, $10 \%$ (p/v) sulfato de amônio e $20 \%$ (v/v) metanol).

Depois de corados os géis são lavados com $1 \%$ (v/v) ácido acético até a eliminação completa do corante excedente. O gel corado é então armazenado em solução contendo $15 \%$ de sulfato de amônio. 


\subsubsection{Obtenção e análise de imagens}

As imagens dos géis bidimensionais foram obtidas por meio do equipamento ImageScaner III, LabScan 6.0 (GE Healthcare). As análises dos géis foram realizadas pelo software ImageMaster 2D Platinum versão 6.0 (GE Healthcare).

As proteínas são reconhecidas isoladamente pelo programa em forma de spots. Os mapas de spots que o programa identifica foram comparados entre mapas da mesma amostra e mapas de amostras diferentes, e avaliaram-se estatisticamente as variações entre eles. Além da comparação entre os mapas protéicos, os spots correspondentes às proteínas de interesse foram analisados isoladamente através das suas imagens tridimensionais, nas quais as proteínas se dispõem no formato de elevações sobre o plano bidimensional do gel, permitindo desse modo a quantificação relativa de cada spot no conjunto de proteínas detectadas pela técnica.

A detecção dos spots foi realizada segundo os parâmetros: smooth $=2$, área mínima $=5$ e saliência $=100.000$. Essa detecção foi realizada pelo modo automático do software. A partir de pontos de referência marcados manualmente o software delega pesos moleculares (PM) e pontos isoelétricos (pI) experimentais dos spots detectados.

\subsection{Identificação das proteínas}

Os spots protéicos de interesse foram extraídos do gel e submetidos à digestão conforme proposto por Shevchenko et al, (1996) modificado.

Os peptídeos digeridos resultantes serão analisados por espectrometria de massas. Esta etapa do trabalho está sendo realizada no Laboratório Nacional de Biociências que pertence ao Laboratório Nacional de Luz Síncrotron - Campinas - SP.

A Figura 8 representa um gel bidimensional de gradiente de $\mathrm{pH} 3$-10, onde estão destacado os spots que foram selecionados e excisados para sequenciamento por espectrometria de massas. 


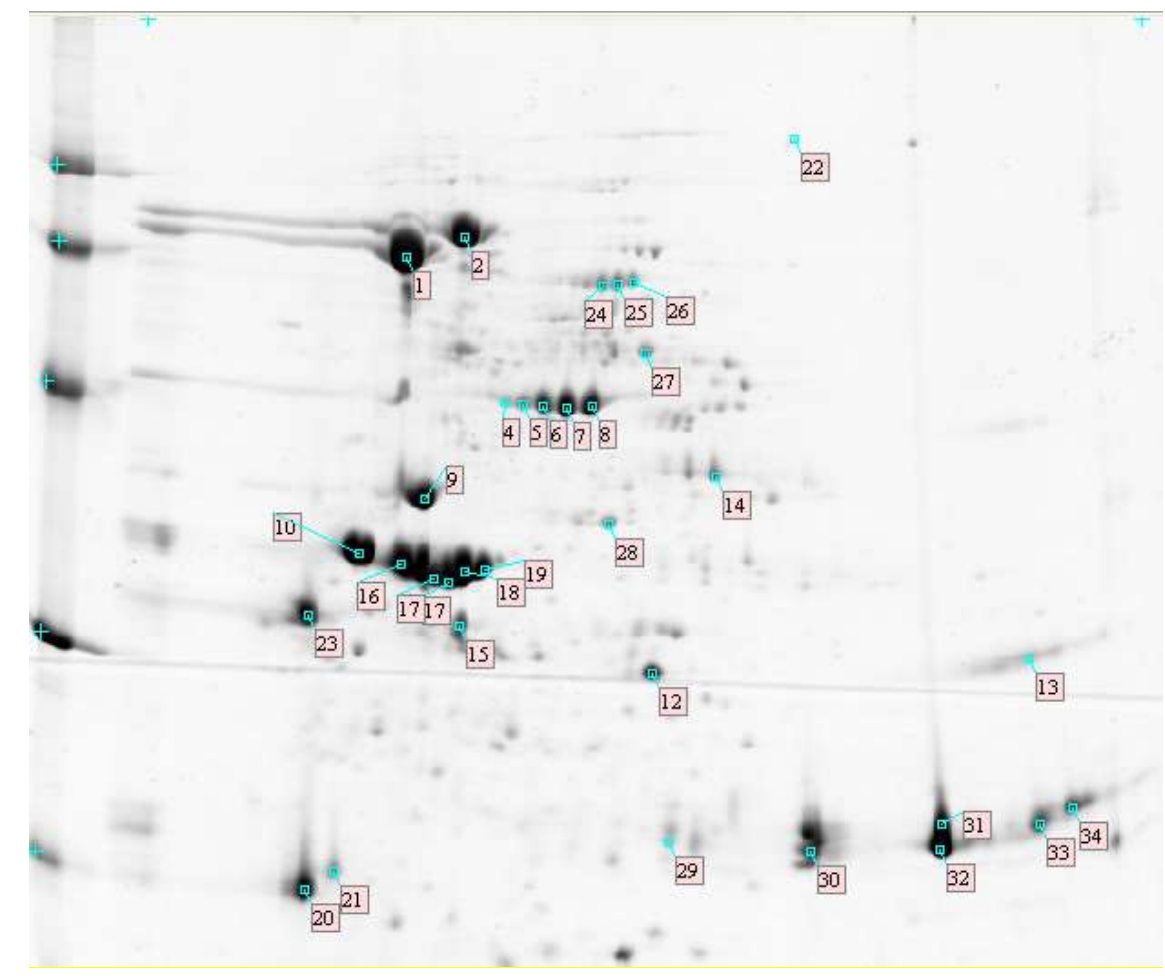

Figura 8: Seleção dos spots extraídos para análise por espectrometria de massas.

\subsubsection{Digestão dos spots}

Foram realizadas as excisões dos peptídeos detectados (spots) nos géis bidimensionais em fragmentos de aproximadamente $1 \mathrm{~mm}$ de diâmetro com o auxilio de bisturi e acondicionados em minitubos. Os fragmentos de géis foram descorados em solução de metanol 50\%/ ácido acético 2,5\%, encubando-os à temperatura ambiente com $0,5 \mathrm{~mL}$ da solução; após 2 h esta etapa foi repetida por mais 1 h e, então, o gel foi removido da solução.

O passo seguinte foi a desidratação dos fragmentos, com a adição de $200 \mu \mathrm{L}$ de acetonitrila $(100 \%)$ por $5 \mathrm{~min}$, repetindo-se esse passo. O restante da acetonitrila foi evaporado a vácuo.

Na etapa seguinte, adicionou-se $30 \mu \mathrm{L}$ da solução de DTT $10 \mathrm{mM}$. Após $30 \mathrm{~min}$ essa solução foi removida e adicionados $30 \mu \mathrm{L}$ da solução de iodoacetamida $50 \mathrm{mM}$. Após mais $30 \mathrm{~min}$, removida essa solução, os fragmentos de géis foram reidratados adicionando $100 \mu \mathrm{L}$ de bicarbonato de amônio $100 \mathrm{mM}$ por $10 \mathrm{~min}$. Removida esta solução, os fragmentos foram desidratados com $200 \mu \mathrm{L}$ de acetonitrila (100\%) por $5 \mathrm{~min}$, repetindo-se os passos da reidratação e desidratação. Evaporou-se o que restou da acetonitrila sob vácuo. 
A tripsina (Promega/ sequence grade) foi preparada para uma concentração final de $20 \mathrm{ng} / \mu \mathrm{L}$, para isso, adicionou-se $20 \mu \mathrm{g}$ de tripsina em $1000 \mu \mathrm{L}$ de bicarbonato de amônio $50 \mathrm{mM}$.

Adicionou-se 30-50 $\mu \mathrm{L}$ da solução de tripsina aos spots por 30 min em banho de gelo. Removeu-se o excesso de solução de tripsina e adicionou-se 5-20 $\mu \mathrm{L}$ de bicarbonato de amônio $50 \mathrm{mM}$ para cobrir o gel. Os tubos permaneceram a $37^{\circ} \mathrm{C}$ durante a noite.

No segundo dia, em cada tubo foram adicionados $10 \mu \mathrm{L}$ de ácido fórmico 5\%, incubado por 10 min à temperatura ambiente. Recolheu-se o sobrenadante em outro minitubo devidamente identificado. Adicionou-se $12 \mu \mathrm{L}$ da solução de ácido fórmico 5\%/ acetonitrila $50 \%$ por 10 min a temperatura ambiente. Coletaram-se os sobrenadantes no minitubo que já continha o extrato do passo anterior e repetiu-se este passo.

As amostras foram para evaporador até restar aproximadamente $1 \mu \mathrm{L}$ e foram armazenadas a $-20^{\circ} \mathrm{C}$ para posterior re-suspensão e identificação por espectrometria de massas.

\subsubsection{Sequenciamento dos peptídeos}

As amostras foram ressuspendidas em solução de ácido fórmico 0,1\%, com agitação em vórtex e centrifugação por de 1000 rpm por 5 min.

O sequenciamento dos peptídeos foi conduzido em plataforma LC-MS/MS com espectrômetro de massas Q-TOF (Waters, Micromass), caracterizado por uma fonte de ionização por eletrospray (ESI) e analisador de massas híbrido, um quadrupolo (Q) associado a um tubo no qual se mede o tempo de vôo dos íons (TOF), acoplado a um sistema on-line de HPLC capilar CaplC (Waters).

Os peptídeos resultantes da digestão foram primeiramente separados a fim de promover a dessalinização da amostra em uma pré-coluna C18 (Sentry Guard, Waters), seguida da retenção dos peptídeos em uma coluna de fase reversa C18 0,32 x 150mm (Symmetry, Waters). O tempo de corrida foi de $10 \mathrm{~min}$.

Para proceder a análise MS, os peptídeos recuperados da coluna foram ionizados por eletrospray a uma voltagem fixa de 3000 volts, temperatura de $90{ }^{\circ} \mathrm{C}$ e 5 psi de $\mathrm{N}_{2}$, e em seguida, foi determinada a razão massa sobre carga $(\mathrm{m} / \mathrm{z})$ de cada peptídeo. 


\subsubsection{Análise das informações}

Os espectros MS/MS gerados pelo sequenciamento dos peptídeos de cada amostra foram processados e analisados pelo programa MASCOT MS/MS Íon Search. Para a busca na base de dados do programa MASCOT, foram selecionados alguns parâmetros que estão especificados na Tabela 3.

Tabela 3: Parâmetros para busca de dados a partir dos espectros MS/MS.

\begin{tabular}{ll}
\hline & Parâmetros para busca de dados no programa MASCOT \\
\hline Banco de dados & VSDB \\
Taxonomia & Tripipsina \\
Enzima & 1 \\
Número de clivagens perdidas & Carbamidomethyl (C) \\
Modificações fixas & Oxidação (M) \\
Modificações variáveis & 50 ppm \\
Tolerância de peptídeos & 0,5 Da \\
Tolerância de fragmentos & $1+, 2+, 3+$ \\
Carga de íons & Monoisotópicas \\
Valores das massas & Micromass (PKL) \\
Formato dos dados & ESI-QUAD-TOF \\
Instrumento & \\
\hline
\end{tabular}

\subsubsection{Identificação das proteínas}

A identificação dos espectros e a correlação de possíveis similaridades com proteínas presentes em bancos de dados foram realizadas automaticamente pelo programa MASCOT.

Quando a proteína é identificada, ela recebe uma pontuação (score) que é obtido pelo valor negativo do logaritmo do probabilidade de valor $\mathrm{m} / \mathrm{z}$ teórico coincidir com o valor $\mathrm{m} / \mathrm{z}$ experimental, portanto, quanto maior o score, menor é a probabilidade daquela identificação ser um evento aleatório. Os pesos moleculares e pontos isoelétricos teóricos foram sugeridos pelo banco de dados NCBI referentes à proteína com maior homologia com cada dado experimental. 


\subsubsection{Análise estatística dos dados}

Quando pertinente, os resultados foram expressos na forma de média. Utilizamos o teste de Kolmogorov-Smirnov para verificar a normalidade dos dados. Para comparações entre mais de dois grupos, quando não rejeitou a normalidade dos dados utilizamos o teste ANOVA, em situação contrária utilizamos o teste de Kruskal-Wallis. Sendo algum destes testes significativos aplicamos comparações múltiplas para verificar qual grupo diferencia. $\mathrm{Na}$ comparação de dois grupos utilizamos o teste t-Student supondo a normalidade, caso rejeitamos a suposição de normalidade dos dados utilizamos o teste da soma de postos de Wilcoxon. Para as análises estatísticas adotamos nível de significância de 5\%. 


\section{RESULTADOS E DISCUSSÃO}

\subsection{Extrações de proteínas}

Para aumentar a resolução dos resultados em proteômica, a amostra deve ser desnaturada, desagregada, reduzida e solubilizada a fim de alcançar a ruptura completa de interações moleculares e garantir que cada ponto represente um polipeptídio individual (GÖRG; WEISS; DUNN, 2004).

Portanto, a extração das proteínas é uma etapa fundamental nos estudos proteômicos, e visa: primeiramente o bom rompimento celular para a exposição das proteínas ao meio, que pode ser por meios mecânicos e/ou químicos; eliminação de interferentes das amostras, como sais, lipídeos, pigmentos, etc; e ainda, ser eficiente na quebra das pontes de hidrogênio e interações hidrofóbicas, para evitar agregações indesejáveis e formação de estruturas secundárias (GÖRG; WEISS; DUNN, 2004).

Natarajan e colaboradores (2005) compararam métodos de solubilização de proteínas de soja, para a verificação do mais adequado para a proteômica. Concluíram que entre os quatro métodos estudados, a extração baseada em uréia/ TCA mostrou a melhor resolução e intensidade das manchas. A partir destas conclusões, realizamos a extração das proteínas de soja com a metodologia referida.

O rendimento da extração verificado neste trabalho foi satisfatório e semelhante entre as amostras convencionais e geneticamente modificadas. O rendimento foi de cerca de $150 \mathrm{mg}$ de proteína por grama de amostra. Resultado semelhante ao encontrado em trabalhos anteriores em nosso laboratório (CASTRO, 2009). 


\subsubsection{Eletroforese unidimensional}

Nos géis unidimensionais, SDS-PAGE, foi possível observar os principais grupos proteícos em todas as amostras, entre os grupos encontrados está a $\beta$-conglicinina (frações $\alpha$, $\alpha^{\prime}$ e $\beta$ ), glicinina (frações ácida e básica) e lipoxigenases (Figura 9). Estas observações foram feitas através de análises comparativas com o trabalhos que identificaram as diferentes frações (FUKUDA et al., 2005; KRISHNAN et al., 2007).
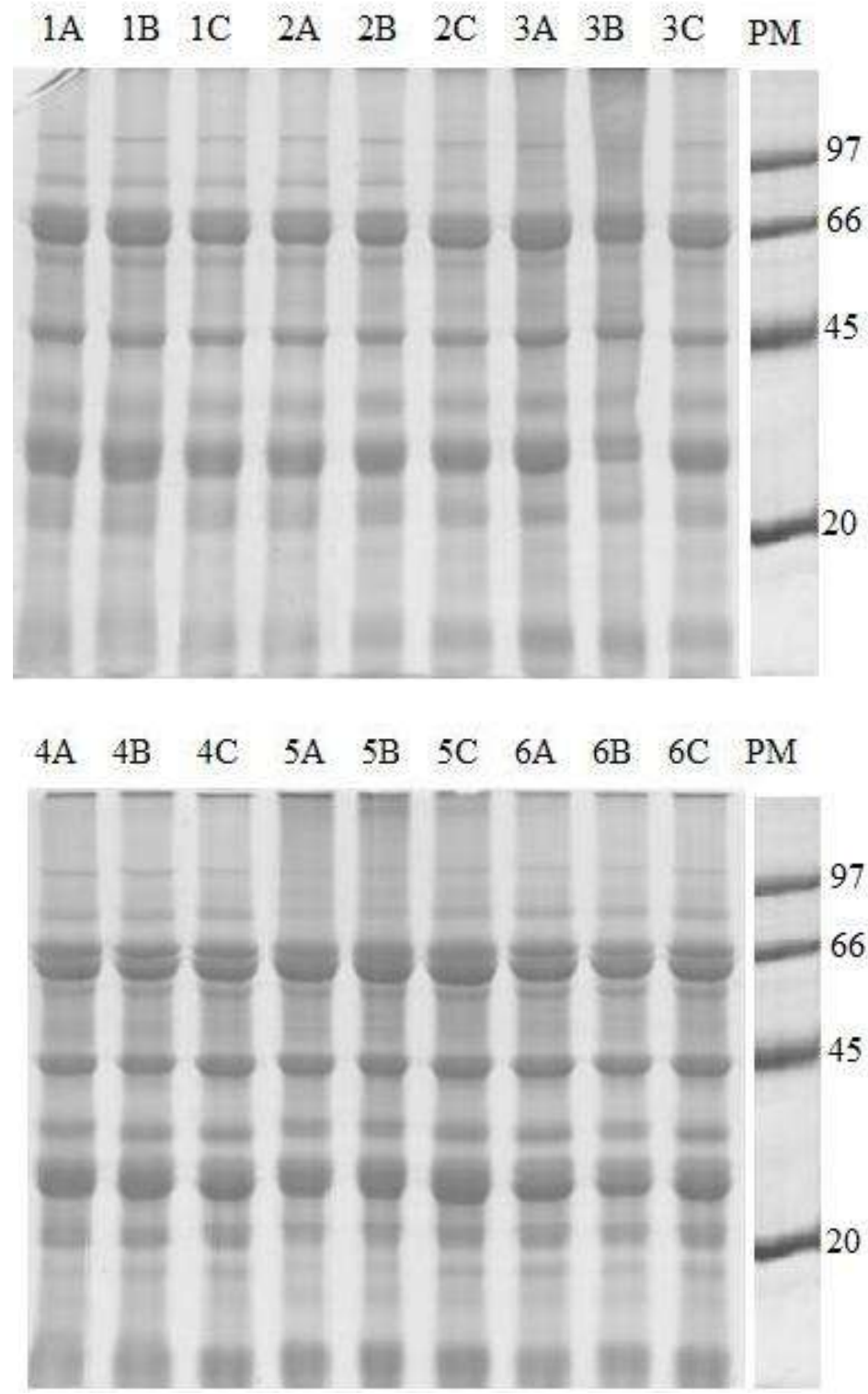

Figura 9: Géis de 12\% de acrilamida corado com Coomassie G-250, resultante de corridas unidimensionais. 1, 3 e 5 correspondem as amostras convencionais e 2, 4 e 6 correspondem as amostras GM. A, B e C correspondem as extrações em triplicata de $30 \mu \mathrm{g}$ de proteínas cada amostra. PM é o peso molecular em kDA. 
O objetivo da corrida em gel unidimensional foi verificar a qualidade e reprodutibilidade da extração proteíca. Neste caso houve ótima reprodutibilidade entre as amostras e perfil proteíco semelhante aos demais trabalhos publicados, de qualidade adequada para a realização da eletroforese bi-dimensional e espectrometria de massas.

Krishnam (2007) e Fukuda (2005) encontraram géis unidimensionais idênticos aos encontrados nas amostras analisadas neste trabalho. Apartir destas literaturas, identificamos os principais grupos proteícos da soja, tanto para as amostras convencionais, quanto para as amostras GM, como pode ser observado na Figura 10.

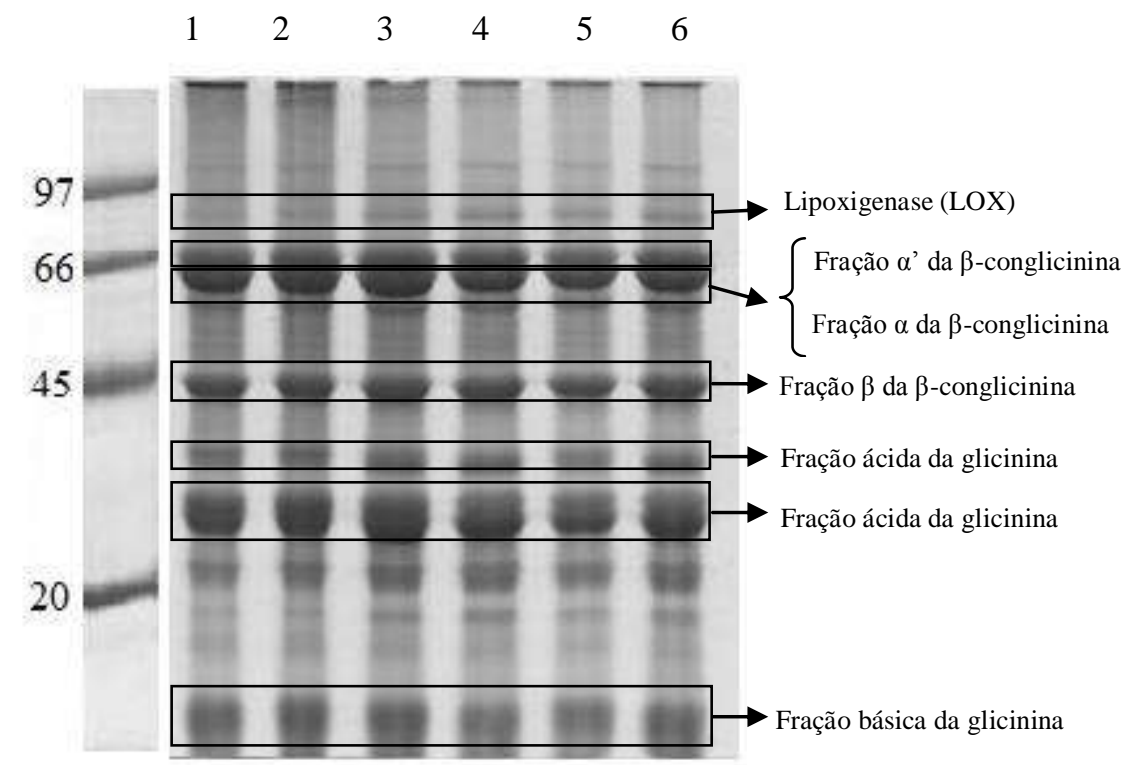

Figura 10: Eletroforese unidimensional, em gel 12\% corado com Coomassie G-250. Gel representa todas as amostras análisadas, sendo que 1, 3 e 5 são amostras convencionais enquanto que as amostras 2, 4 e 6 são as correspondentes geneticamente modificadas. Destaque para os principais grupos proteícos presentes na soja que são possíveis de visualizar com a eletroforese 1D.

A Glicinina é a proteínas mais abundante na soja e é composta por 6 subunidades: A1aB2, A1bB1b, A2B1a, A3B4 e A5A4B3 (MORAES et al., 2006; L'HOCINE; BOYE; JOUVE, 2007; NATARAJAN et al., 2007 ${ }^{\mathrm{A}}$ ). No gel 1D é possível reconhecer 2 frações de glicinina, uma ácida e outra básica, porém não é possível destacar qual subunidade as bandas representam. 
A $\beta$-conglicinina é a segunda proteína de reserva mais presente na soja, e é composta por 3 subunidades: $\alpha^{\prime}$ que apresenta peso molecular entre $57-72 \mathrm{kDa}, \alpha$ com PM entre 57 - $68 \mathrm{kDa}$ e $\beta$ com PM entre 42 - 52 kDa (THANH; SHIBASAKI, 1977). As subunidades de $\beta$-conglicinina são possíveis identificar na eletroforese 1D quando comparado com a literatura (KRISHNAM et al., 2007; FUKUDA et al., 2005).

Entre os fatores antinutricionais, apenas uma fração de lipoxigenase é possível identificar por eletroforese 1D. As lipoxigenases correspondem a cerca de 1\% das proteínas da soja (MONTEIRO et al., 2004). As LOX são proteínas alongadas com peso molecular de 103 kDa (PRIGGE et al., 1997).

Os demais fatores antinutricionais, como o inibidor de protease tipo Kunitz e o Inibidores de proteases Bowman-Birk não são possíveis de observar neste tipo de eletroforese devido a baixa concentração destas proteínas e também pelos seus baixos pesos moleculares (20 e $10 \mathrm{kDa}$ respectivamente) (FRIEDMAN et al., 1991).

A eletroforese 1D apresenta limitações, pois, os géis produzidos a partir desta metodologia mostram bandas muito próximas e difíceis de definir, o que dificulta a identificação das proteínas e subunidades que as compõem, além, da dificuldade de identificar proteínas menos abundantes, como o caso dos inibidor de protease tipo Kunitz e BowmanBirk citados anteriormente. Desta maneira, faz-se uso de uma metodologia que melhore a distribuição das proteínas no gel, facilitando a identificação das mesmas, para posteriores análises comparativas de perfis protéicos de diferentes amostras.

\subsection{Eletroforese bidimensional}

Após a adequada extração proteíca, a eletroforese bi-dimensional (2D) é o segundo passo para a análise proteômica. Na eletroforese 2D, os spots, que são as manchas reveladas nos géis, representam uma proteína individual e o conjunto destes spots é conhecido como mapa proteíco. Com os mapas proteícos é possível comparar as diferentes amostras, no caso do presente trabalho, comparar os mapas proteícos das amostras convencionais com as suas respectivas amostras geneticamente modificadas e adicionalmente, comparação com amostras orgânicas.

As pesquisas em alimentos e em organismos geneticamente modificados tem utilizando cada vez mais as ferrametas proteômicas (espectrometria de massas combinado 
com a eletroforese bidimensional em gel), pois, colaboram na identificação de alterações pós traducionais, mudanças da composição proteíca, nível de expressão de proteínas, interações proteína-proteína e consequentemente na avaliação da qualidade destes novos alimentos (BATISTA et al., 2007; VALLEDOR; JORRIN, 2011). Quando a técnica é executada corretamente, obtem-se dados consistentes sobre a massa molecular, pontos isoelétricos e variações entre amostras (NATARAJAM et al, 2006; GÖRG; WEISS; DUNN,, 2004).

Outro uso justificável das ferramentas proteômicas nas amostras de soja é o seu crescente emprego em produtos alimentícios industrializados e isso torna-se uma ameaça potencial quando consumido por pessoas alérgicas às proteínas da semente (HERMAN et al, 2003). A soja está contida no grupo dos oito alimentos documentados como causadores de 90\% das alergias alimentares (BATISTA et al., 2007; L'HOCINE; BOYE; JOUVE, 2007).

Na eletroforese 2D, optamos por trabalhar com tiras de gradiente de $\mathrm{pH}$ de 3-10, por saber que a soja apresenta um abundante perfil proteíco, e dessa forma conseguir um maior número de spots. Com os géis com gradiente de $\mathrm{pH}$ de 3-10 realizamos as análises comparativas e o trabalho estatístico. Alguns géis com gradiente de $\mathrm{pH}$ de 4-7 foram obtidos, e até realizamos comparações superficiais entre os mesmos, mas estes géis serviram principalmente para facilitar a separação e a excisão dos spots desta região, para posterior análise no espectrômetro de massas e identificação de proteínas específicas destas regiões.

A Figura 11 representa o gel com pH de 3-10 e a Figura 12 o gel de pH 4-7. Como se pode observar, no gel de $\mathrm{pH}$ 4-7 os spots de espaçam melhor, porém, nesta faixa de $\mathrm{pH}$ perdem-se spots de $\mathrm{pH}$ mais extremos.

Atualmente, muitos trabalhos comparativos utilizam o $\mathrm{pH}$ de 3-10 em suas análises (HERMAN et al., 2003, ZHEN et al., 2007; XU et al., 2006), este fato pode ser entendido pela característica do gel de exibir maiores quantidades de dados e desta maneira, maior possibilidade de detecção de alterações entre diferentes grupos de amostras.

$\mathrm{Xu}$ e colaboradores (2006) optaram por trabalhar com gradiente de $\mathrm{pH}$ de 3-10 e identificação de um amplo número de spots. Obtiveram ótimos resultados, porém relataram da dificuldade de separação/excisão dos spots de frações menos intensas e muito próxima. Nestes casos é justificavel o uso de tiras com gradiente de pH 4-7 para a separação das proteínas que apresentam pesos moleculares e pontos isoelétricos próximos.

Natarajan e colaboradores $\left(2007^{\mathrm{A}}\right)$ objetivaram comparar o perfil proteômico e genômico das subunidades de Glicinina em 16 diferentes genótipos de soja. Por se tratar de um grupo próteico específico e não um perfil geral, optaram por trabalhar com gradientes de 
pH de 4-7 e ainda de pH 6-11. Desta forma, obtiveram géis bem definidos e com proteínas espaçadas o suficiente para excisão e futuras análises comparativas.

Destacamos a fração ácida de glicinina, identificada por comparação com o trabalho de Herman e colaboradores (2003) e confimação com espectrometria de massas. Este destaque ajuda a visualizar as diferenças nas separações dos spots entre os dois diferentes gradientes de $\mathrm{pH}$ (3-10 e 4-7).
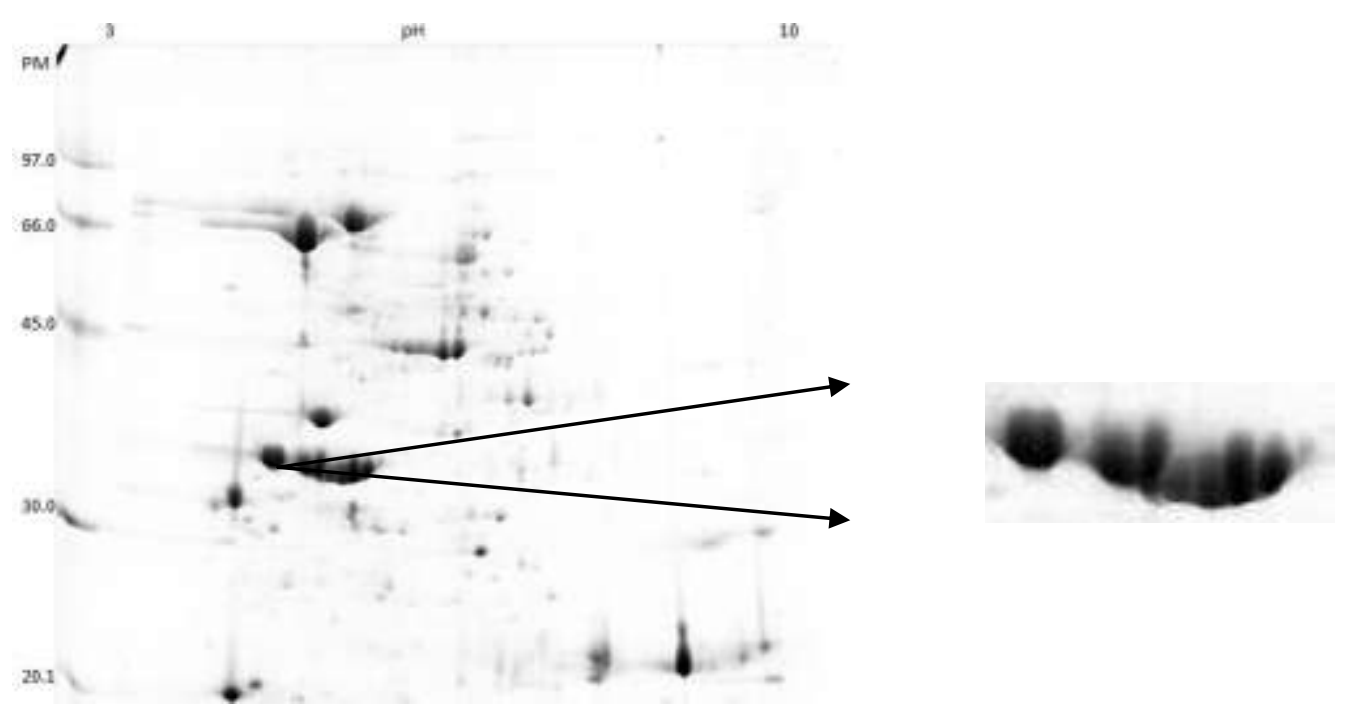

Figura 11: Mapa protéico em gel bidimensional com faixa de $\mathrm{pH}$ de 3-10, com destaque para a fração ácida de glicinina. Gel preparado com $12 \%$ de acrilamida e corado com Comassie G-250.
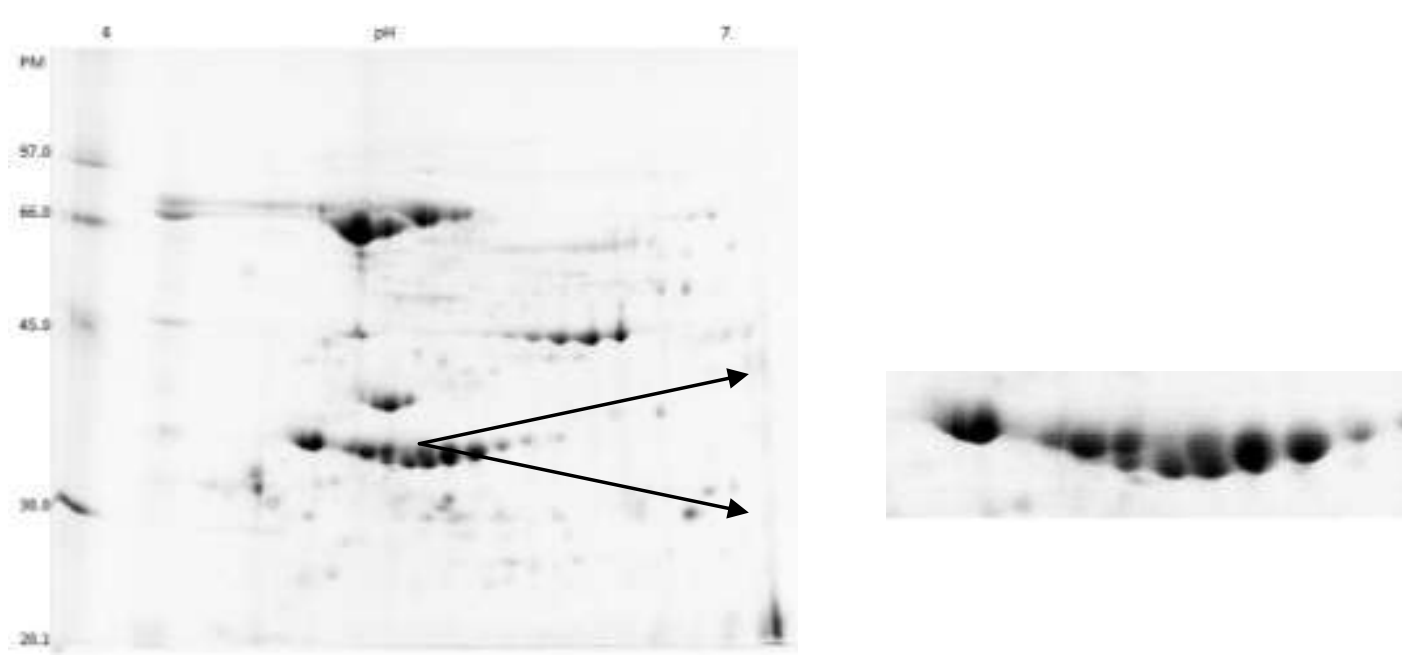

Figura 12: Mapa protéico em gel bidimensional com faixa de $\mathrm{pH}$ de 4-7, com destaque para a fração ácida de glicinina. Gel preparado com $12 \%$ de acrilamida e corado com Comassie G-250. 


\subsection{Identificação da frações proteícas}

Com a eletroforese $2 \mathrm{D}$, é possível a identificação de algumas proteínas, pois, possuímos os valores de peso molecular e ponto isoelétrico dos spots identificados pelo programa (GÖRG; WEISS; DUNN, 2004). Em uma primeira análise dos géis bidimensionais é possível observar muitas semelhanças entre as amostras, inclusive na comparação entre amostra geneticamente modificada e sua estirpe genitora.

Na Figura 13, é possível observar a presença de grandes grupos proteícos da soja como as proteínas de reserva e fatores anti-nutricionais.

A eletroforese 2D é a tecnologia chave para estudar as diferenças no nível de expressão de proteínas em várias amostras (ERAVCI et al., 2007). Com esta visualização inicial dos principais grupos proteícos podemos perceber qua não há diferenças aparentes entre as distintas amostras, tanto convencionais, quanto geneticamente modificadas.

A análise das imagens é um passo crucial nos trabalhos com proteômica e tem impacto direto na obtenção de dados qualitativos e quantitativos. Como a análise é um processo complexo e gera grandes quantidades de dados, a utilização de softwares é inevitável (STESSL; NOE; LACHMANN, 2009), no entanto é imprescindível estabelecer alguns critérios para os limites de detecção, conforme será discutido mais à frente, durante a análise das 

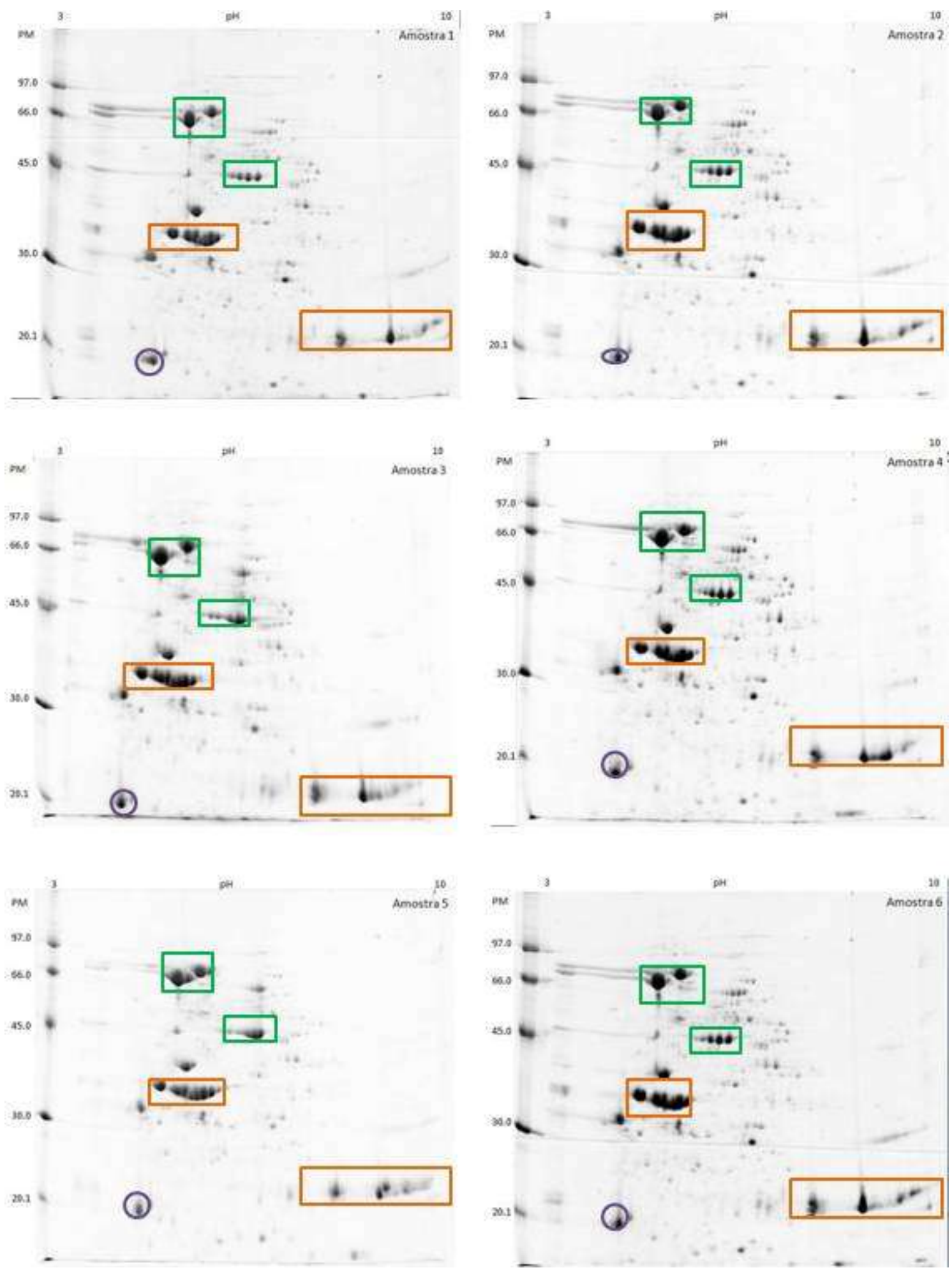

Figura 13: Géis bidimensionais das amostras 1,3 e 5 que representam amostras convencionais, e 2, 4 e 6 que representam amostras GM. Os spots marcados com retângulos laranjas correspondem as frações de glicinina, os retângulos verdes correspondem as frações de $\beta$-conglicinina e os círculos roxos corresponde ao inibidor de tripsina de acordo com Herman et al, 2003 e confimado por espectometria de massas. 
imagens em cada conjunto de amostras avaliado. Assim, amostras protéicas de espécies distintas devem ser estabelecidos critérios próprios nos níveis de sensibilidade e exclusão de spots.

Conforme já citado anteriormente, a soja apresenta cerca de $40 \%$ de proteínas (KRISHNAN et al., 2007). Destas, 70\% representam glicinina e $\beta$-conglicinina, que são dois grandes e abundantes grupos de proteínas de reserva da soja (HILL; BREIDENBACH, 1974b; KRISHNAN, et al., 2007; L'HOCINE; BOYE; JOUVE, 2007; CARRÃO-PANIZZI et al., 2008).

A partir dos mapas protéicos obtidos, com os dados de pesos moleculares e pontos isoelétricos, comparações com a literatura (HERMAN et al., 2003; BATISTA et al., 2007; XU et al., 2006; ) e resultados da espectrometria de massas, foi possível reconhecer estes principais grupos e algumas de suas frações.

Herman e colaboradores (2003) compararam perfis proteícos de soja GM e não GM, nos quais analisaram a possíbilidade de silenciar geneticamente uma proteína alergênica da soja e provaram que mesmo com a alteração, houve equivalência substancial entre as sementes.

Batista e seus colaboradores (2007) avaliaram o proteoma de sojas transgênicas e não transgênicas, com o intuito de identicar mudanças entre os perfis protéicos e ainda, na tentativa de identificar diferentes respostas de pacientes alérgicos a soja frente a modificação genética. Concluiram tratar de uma poderosa ferramenta (a união das técnicas de 2D e MASS) para a avalição da segurança de plantas e alimentos e a expressão dos alérgenos pareceu não ter sido alterada após a modificação genética (BATISTA et al., 2007).

\subsection{Detecção dos spots}

Com o auxilio do software ImageMaster 2D Platinum versão 6.0 (GE Healthcare), foi possível fazer o reconhecimento isolado dos spots. Os spots compreendem as proteínas que migraram pelo gel bidimensional de acordo com seus pontos isoelétricos e massas moleculares e posteriormente reveladas com o corante Commassie G-250.

A separação de misturas complexas como proteínas por eletroforese é uma prática comum e bastante efetiva (ZHEN et al., 2007; NATARANJAN et al., 2007). Trata-se de uma 
técnica de migração da amostra aplicada, sob a ação de um campo elétrico. Na primeira dimensão da eletroforese 2D, as amostras migram até que as suas cargas tornem-se nulas, ou seja, o seu ponto isoelétrico $(\mathrm{pI})$ se iguale ao $\mathrm{pH}$ do gradiente.

Para evitar interações hidrofóbicas entre os domínios protéicos e evitar perda de proteínas devido à agregação e/ou precipitação, faz-se uso de surfactantes como o SDS (duodecil sulfato de sódio) e CHAPS (3-[(3-colamidopropil)-dimetilâmonio]-1propanosulfonato). Estes atuam minimizando as cargas e formas das proteínas, a fim de que migrem apenas pela ação das suas massas moleculares (segunda dimensão da eletroforese 2D). Estudos têm demonstrado um maior desempenho quando dois detergentes são associados, principalmente se forem de características aniônicas (SDS) e zwitteriônicas (CHAPS) (GÖRG; WEISS; DUNN, 2004).

Além dos surfactantes, os agentes caotrópicos como a uréia e a tiouréia, também são responsáveis por quebrar ligações de hidrogênio e interações hidrofóbicas. Desta forma evitando agregação e formação de estruturas secundárias indesejáveis (SHAW et al., 2003). Também faz parte do meio o DTT, um agente redutor que tem o papel de clivar as pontes dissulfetos formadas pelos resíduos de cisteína e de manter o meio redutor. Além disso, com o rompimento das ligações que o DTT provoca, facilita o acesso do SDS nas proteínas (GÖRG; WEISS; DUNN, 2004).

O uso de poliacrilamida como matriz para o gel é comumente utilizado em experimentos eletroforéticos, por ser um material que não interage com a amostra, ser transparente e ainda ser estável em amplas faixas de $\mathrm{pH}$, força iônica e temperatura. A matriz poliacrilamida é polimerizada a partir de acrilamida e bis-acrilamida.

Tanto o DTT quando a iodacetamida participam da etapa de equilíbrio das tiras após a etapa de focalização isoelétrica. Primeiramente o DTT atua reduzindo as pontes dissulfetos e depois a iodoacetamida atua na alquilação das proteínas contidas nas tiras antes de aplicá-las sobre o gel para a segunda dimensão. A iodoacetamida apresenta papel importante na alquilação dos grupos sulfidrila e prevenção da reoxidação. Esta etapa é recomendada quando é realizada posteriormente a identificação dos peptídeos por espectrometria de massas (GÖRG; WEISS; DUNN, 2004).

A detecção dos spots é uma das primeiras análises que os softwares fornecem. A partir desta informação é possível obter dados quantitativos sobre spots, dados de harmonização e sobreposição dos mesmos, valores estimados de pontos isoelétricos e pesos 
moleculares e consequentemente a criação de perfis de expressão das respectivas proteínas (BERTH et al., 2007).

A Figura 14 mostra os géis de referência para cada amostra com gradiente de $\mathrm{pH}$ 3-10 e a Figura 15 mostra um gel com gradiente de $\mathrm{pH}$ de 4-7 com seus respectivos spots detectados pelo software e posteriormente editados manualmente.

Antes de digitalizá-los, os géis foram lavados com 1\% (v/v) ácido acético em água destilada para descorar o fundo do gel, que geralmente encontra-se azulado por conta do corante Commassie G-250.

O software detecta os spots apartir de parâmetros pré-estabelecidos, como, smooth $=2$, área mínima $=5$ e saliência $=100.000$. O parâmetro smooth determina o número de vezes que o programa homogeniza a região antes de seguir a detecção; área mínima determina a região mínima para a detecção, eliminando regiões menores que as estabelecida; e saliência é a medida em pixel da base do gel até o final da curvatura do spots.

Essa detecção foi realizada de modo automático do software. Porém, para eliminar spots falsos positivos, reconhecer spots que o software não reconheceu, ou ainda delimitar área de spots é necessário uma edição manual. Esta, apesar de tediosa, é de extrema importância para garantir a consistência dos resultados.

Na edição manual também são marcados os padrões de pesos moleculares, que correram junto com a amostra e o início e fim do gradiente de $\mathrm{pH}$, fator que se altera pela posição da tira de IPG (immobilized pH gel) no topo do gel. 

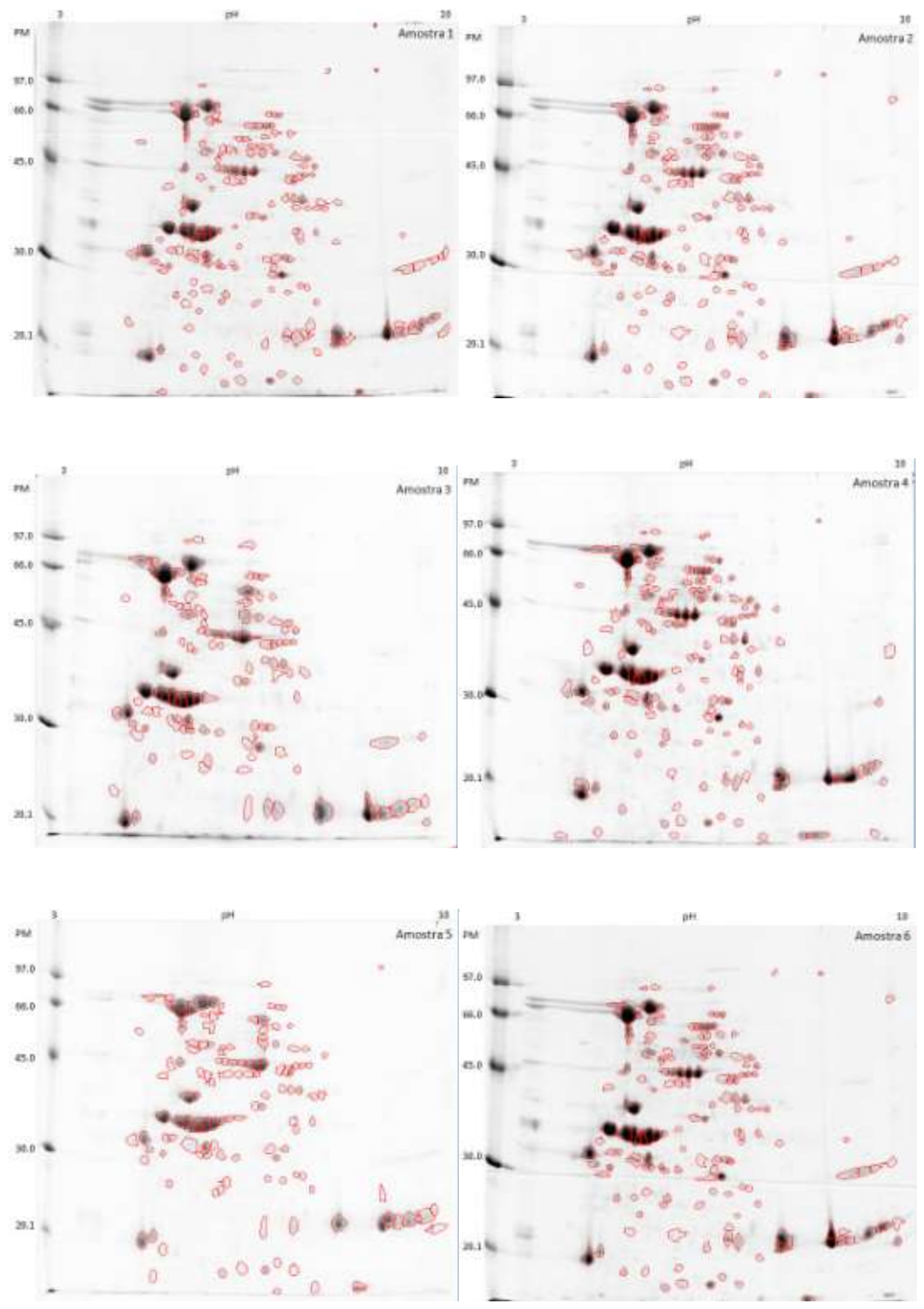

Figura 14: Spots detectados pelo software ImageMaster 2D Platinum a partir de geis bidimensionais com gradiente de $\mathrm{pH}$ de $3-10$. As amostras 1,3 e 5 correspondem as amostras convencionais e as amostras 2,4 e 6 correspondem as amostras GM. 


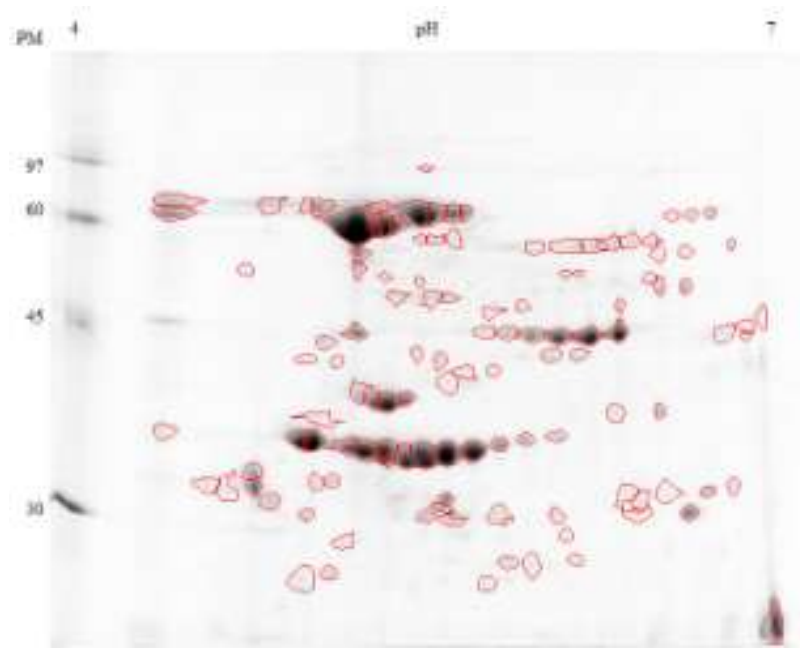

Figura 15: Spots detectados pelo software ImageMaster 2D Platinum de gel bidimensional da amostra $1 \mathrm{com}$ gradiente de $\mathrm{pH}$ de $4-7$.

\subsubsection{Número de spots detectados}

Após a edição manual foi possível quantificar os spots no mapa protéico. A Tabela 4 apresenta o número de spots para as diferentes amostras.

Alguns autores sugerem número de replicatas suficientes para fazer um trabalho estatístico com os resultados (VALLEDOR; JORRIN, 2011). Já Meunier e colaboradores (2005) sugerem no mínimo três réplicas dos géis, mas quando possível, cinco replicas. Como realizamos três extrações de cada amostra, consequentemente obtivemos 9 géis de cada amostra.

Para a análise do número de spots das amostras, comparamos as amostras genitoras com suas variedades geneticamente modificadas ( 1 e 2,3 e 4,5 e 6 ).

Aplicamos o teste de Kolmogorov-Smirnov para verificar a normalidade dos dados. Como o teste não rejeitou a normalidade foi também aplicado o teste T-Student. Com o teste verificamos que não houve diferença estatística ao nível de significância de $5 \%$ ( $\mathrm{p}=$ 0,44 para as amostras 1 e $2, p=0,35$ para as amostras 3 e 4 e $p=0,11$ para as amostras 5 e 6 ). 
Tabela 4: Número de spots detectados pelo software ImageMaster 2D Platinum para as diferentes amostras, extrações e suas triplicatas em géis de acrilamida $12 \%$, gradiente de $\mathrm{pH}$ 3-10.

\begin{tabular}{llllll}
\hline Amostra & $\begin{array}{c}\text { Número de } \\
\text { spots }\end{array}$ & Amostras & $\begin{array}{c}\text { Número de } \\
\text { spots }\end{array}$ & Amostras & $\begin{array}{c}\text { Número de } \\
\text { spots }\end{array}$ \\
\hline 1 A I & 173 & 2 A I & 169 & 3 A I & 154 \\
1 A II & 117 & 2 A II & 160 & 3 A II & 139 \\
1 A III & 120 & 2 A III & 137 & 3 A III & 167 \\
1 B I & 155 & 2 B I & 113 & 3 B I & 122 \\
1 B II & 129 & 2 B II & 107 & 3 B II & 109 \\
1 B III & 142 & 2 B III & 101 & 3 B III & 116 \\
1 C I & 106 & 2 C I & 118 & 3 C I & 80 \\
1 C II & 132 & 2 C II & 138 & 3 C II & 95 \\
1 C III & 151 & 2 C III & 105 & 3 C III & 98 \\
\hline MÉDIA & $\mathbf{1 3 6}$ & MÉDIA & $\mathbf{1 2 7 , 5}$ & MÉDIA & $\mathbf{1 2 0}$ \\
\hline
\end{tabular}

\begin{tabular}{llllll}
\hline Amostra & $\begin{array}{c}\text { Número de } \\
\text { spots }\end{array}$ & Amostras & $\begin{array}{c}\text { Número de } \\
\text { spots }\end{array}$ & Amostras & $\begin{array}{c}\text { Número de } \\
\text { spots }\end{array}$ \\
\hline 4 A I & 152 & 5 A I & 109 & 6 A I & 121 \\
4 A II & 127 & 5 A II & 109 & 6 A II & 115 \\
4 A III & 164 & 5 A III & 99 & 6 A III & 148 \\
4 B I & 171 & 5 B I & 107 & 6 B I & 115 \\
4 B II & 110 & 5 B II & 112 & 6 B II & 159 \\
4 B III & 132 & 5 B III & 129 & 6 B III & 124 \\
4 C I & 104 & 5 C I & 137 & 6 C I & 105 \\
4 C II & 106 & 5 C II & 117 & 6 C II & 133 \\
4 C III & 124 & 5 C III & 101 & 6 C III & 112 \\
\hline MÉDIA & $\mathbf{1 3 2}$ & MÉDIA & $\mathbf{1 1 3}$ & MÉDIA & $\mathbf{1 2 6}$ \\
\hline
\end{tabular}

Para facilitar a excisão dos spots dos géis para posterior digestão e identificação por espectrometria de massas, realizamos algumas corridas de géis com gradiente de $\mathrm{pH}$ de 47. Destes, realizamos também algumas análises de imagens para complementar e amplificar nossa pesquisa. 
Tabela 5: Número de spots detectados pelo software ImageMaster 2D Platinum para as diferentes amostras, extrações e suas triplicatas em géis de acrilamida 12\%, gradiente de $\mathrm{pH}$ 4-7.

\begin{tabular}{cc}
\hline Amostra & $\mathbf{N}^{\mathbf{0}}$ de spots \\
\hline 1A & 97 \\
1B & 90 \\
2A & 99 \\
2B & 96 \\
3A & 80 \\
3B & 86 \\
4A & 93 \\
4B & 89 \\
5A & 116 \\
5B & 116 \\
6A & 89 \\
6B & 97 \\
\hline MÉDIA & $\mathbf{9 5 , 7}$ \\
\hline
\end{tabular}

Com auxílio do programa e posterior edição manual, nos géis com gradiente de pH de 3-10 foram detectados 136, 120 e 113 como números médios de spots para as amostras genitoras 1,3 e 5, e 127,5, 132 e 126 spots para as amostras 2, 4 e 6, que são as correspondentes GMs, respectivamente. Estes resultados condizem com os valores encontrados em nosso laboratório por Castro (2009), porém os valores encontrados para nossas amostras são um pouco aumentados em relação ao trabalho anterior. Importante observar, que para fazer uma comparação entre os valores do número de spots encontrados, é necessário que parâmetros como smooth, área mínima e saliência pré-estabelecidos sejam iguais nos dois conjuntos de amostras, seguidos no presente trabalho.

Um dado interessante foi que a amostra 5, nos géis de $\mathrm{pH} 3-10$, foi a amostra que apresentou a menor média de spots detectados, já para nos géis de $\mathrm{pH} 4-7$, foram detectados os maiores valores de spots. Apesar desta constatação, não identificamos justificativa para este ocorrido.

Brandão e colaboradores (2010) obtiveram valores maiores de spots tanto para os géis com gradiente de $\mathrm{pH}$ de 4-7 como para $\mathrm{pH} 3-10$, porém os autores trabalharam com variadas concentrações de proteínas e parâmetros diferentes ( smooth $=3$, área mínima $=48$ e saliência $=60$ ). O risco de usar parâmetros inferiores, como os utilizados por Brandão, é a detecção de um número aumentado de spots falsos positivos o que dificulta a identificação dos spots corretos no momento da edição manual. 
As ferramentas proteômicas, também são utilizadas na pesquisa e comparação da expressão de spots de outras culturas GMs e não GMs, como por exemplo, o milho e farinha de milho (ZOLLA et al., 2007; ALBO et al., 2007). Albo e colaboradores (2007) perceberam diferenciações na expressão de dois spots na farinha de milho, porém, não avaliaram tal diferença como uma característica desfavorável do novo alimento e sim, uma alteração natural decorrente da modificação genética.

\subsection{Matching entre extrações}

Uma das formas de comparar os géis bidimensionais é pelo processo de matching, que consiste na sobreposição das imagens para identificar os spots equivalentes entre os pares de géis. Trabalhamos com triplicatas das extrações, de cada extração reconhecemos um gel como referência, que corresponde ao gel que apresentou maior número de spots.

Para o processamento do matching, é necessário selecionar referências, ou landmarks, que são proteínas conhecidas e que são possíveis de identificar em todos os géis. Neste trabalho selecionamos três landmarks, que consideramos como aspecto positivo, pois a literatura relata que se for possível obter um bom matching partindo de poucos landmarks, sinaliza que o gel não sofreu distorções ou desalinhamento durante a corrida ou preparo do gel.

Tabela 6: Spots comuns entre as extrações das amostras em relação aos géis de referência.

\begin{tabular}{clll}
\hline Amostra & Extração referência & $\mathbf{N}^{\mathbf{0}}$ de spots comuns & \% de matching \\
\hline 1 & 1 A III & 95 & 73,9 \\
& 1 C II & 77 & 63,4 \\
\hline 2 & 2 B II & 94 & 70,7 \\
& 2 C I & 97 & 71,6 \\
\hline 3 & 3 B I & 106 & 76,5 \\
& 3 C III & 90 & 71,1 \\
\hline 4 & 4 B I & 142 & 84,8 \\
& 4 C III & 107 & 74,3 \\
\hline 5 & 5 A II & 99 & 80,5 \\
& 5 B II & 93 & 74,7 \\
\hline 6 & 6 A I & 105 & 75,5 \\
& 6 C II & 95 & 71,4 \\
\hline
\end{tabular}


Tabela 7: Spots comuns entre diferentes amostras de soja convencional e suas correspondentes GM. 1, 3 e 5 correspondem as amostras convencionais e 2, 4 e 6 correspondem as amostras GM.

\begin{tabular}{ccc}
\hline Amostras & $\mathbf{N}^{\mathbf{0}}$ de spots comuns & \% de matching \\
\hline 1 e 2 & 145 & 87,1 \\
3 e 4 & 131 & 79,6 \\
5 e 6 & 101 & 74,8 \\
\hline
\end{tabular}

Comparamos tanto a sobreposição entre as triplicatas, entre as extrações (Tabela 6) para verificar a reprodutibilidade dos géis, e também a sobreposição entre os géis referência de cada amostra convencional e sua correspondente GM (Tabela 7) para a verificação das suas similaridades.

A partir das tabelas de resultados dos matchings, foi possível avaliar que os géis apresentaram qualidade e semelhança satisfatória, com porcentagem de matching superior a $70 \%$, que é o preconizado como valor representativo de bom índice de sobreposição (BRANDÃO; BARBOSA; ARRUDA, 2010). Com este resultado, é possível afirmar que os perfis protéicos entre as diferentes amostras são similares.

Os resultados das sobreposições das triplicatas de cada extração não estão expostos na forma de Tabela, porém, também realizamos essas análises e todos os resultados destes matchings apresentaram-se dentro do que adotamos como satisfatório (acima de 70\%).

Tanto Castro (2009) quanto Brandão (2010) obtiveram sobreposições na magnitude acima de $70 \%$, confirmando os valores obtidos em nossos experimentos.

Sussulini (2007) obteve resultados bastante reprodutíveis em seus experimentos, com porcentagem de sobreposição acima de $70 \%$ para as replicatas das amostras, como os valores encontrados para a sobreposição em nossas amostras. Porém quando sobrepôs imagens dos géis transgênicos com os géis não transgênicos obtiveram a probabilidade de identidade de $65,2 \%$, mas considerou que as magnitudes de sobreposição acima de $50 \%$ como ótimas. No caso presente, a menor porcentagem de sobreposição ocorreu entre as amostras 5 e $6 \operatorname{com} 74,8 \%$.

Pode-se questionar o que representam os spots que não se sobrepuseram, principalmente quando relatamos diferenças na sobreposição de réplicas de géis da mesma amostra. Mesmo os géis que são executados em condições idênticas, as variabilidades ocorrem, que podem ser baseadas principalmente em dois fatores: procedimentos 
experimentais e análise de imagem subsequente. Variações resultantes de diferentes etapas da operação como hidratação insuficiente das tiras e falta de homogeneidade nos procedimentos de coloração, são fatores citados repetidamente (STESSL; NOE; LACHMANN, 2009).

Outros autores citam que as diferenças são justificáveis pela técnica ser bastante elaborada, e também pela influencia de fatores externos como temperatura, corrente, variações na polimerização do gel e manipulador (ERAVCI et al., 2007).

Por se tratar de um experimento com um $\boldsymbol{n}$ alto, principalmente pelo número de extrações e suas triplicatas (condição que a técnica exige), os ensaios foram realizados em dias diferentes e estes fatores externos se justificam.

As figuras a seguir representam os géis convencionais e seus correspondentes GM que foram sobrepostos para o processamento do matching. São os géis correspondentes aos resultados da Tabela 7 . 


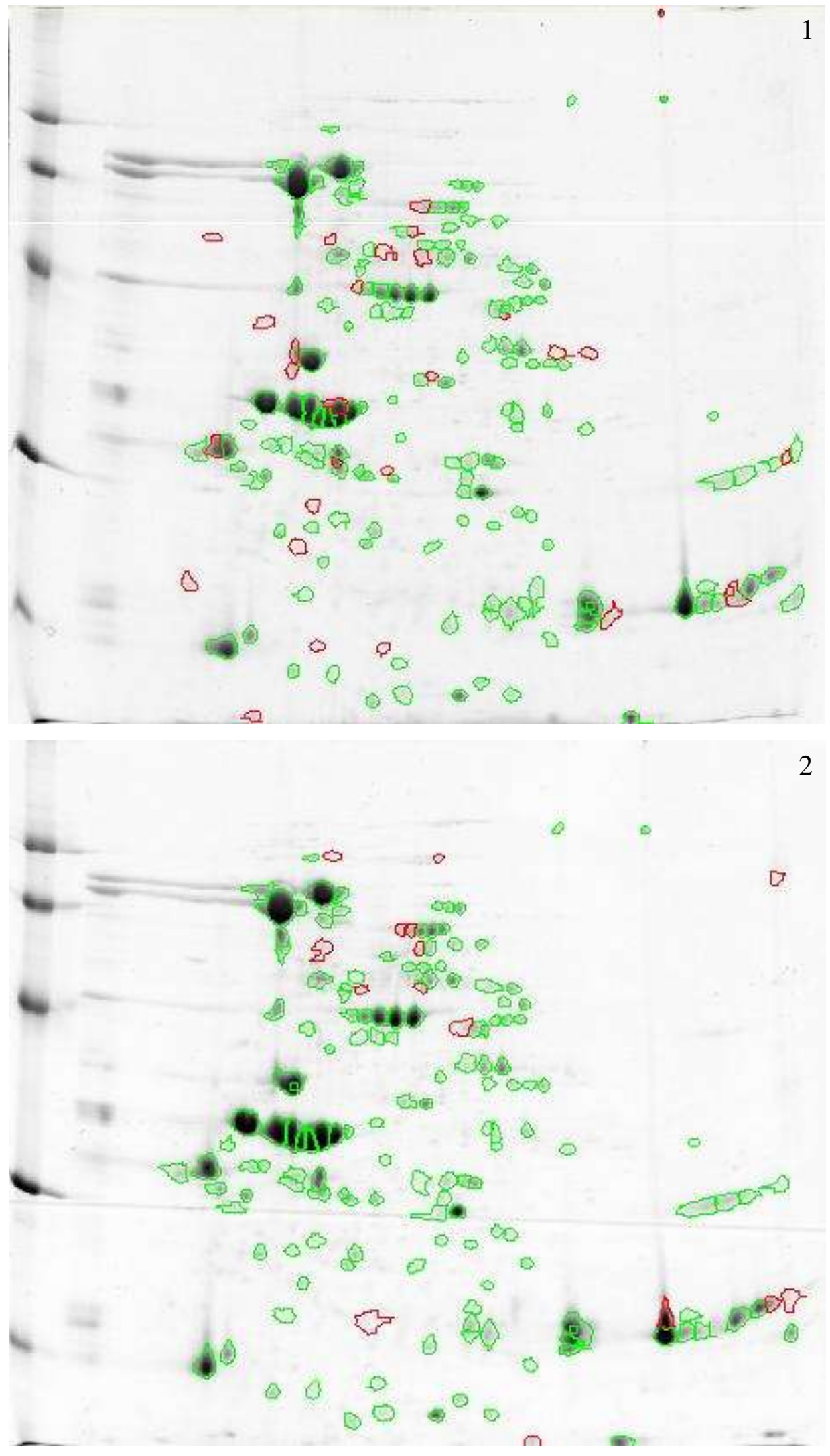

Figura 16: Matching entre a amostra convencional 1 e sua respectiva GM, amostra 2. Os spots que se sobrepuseram estão destacados em verde e os que não apresentaram sobreposição estão em vermelho. 


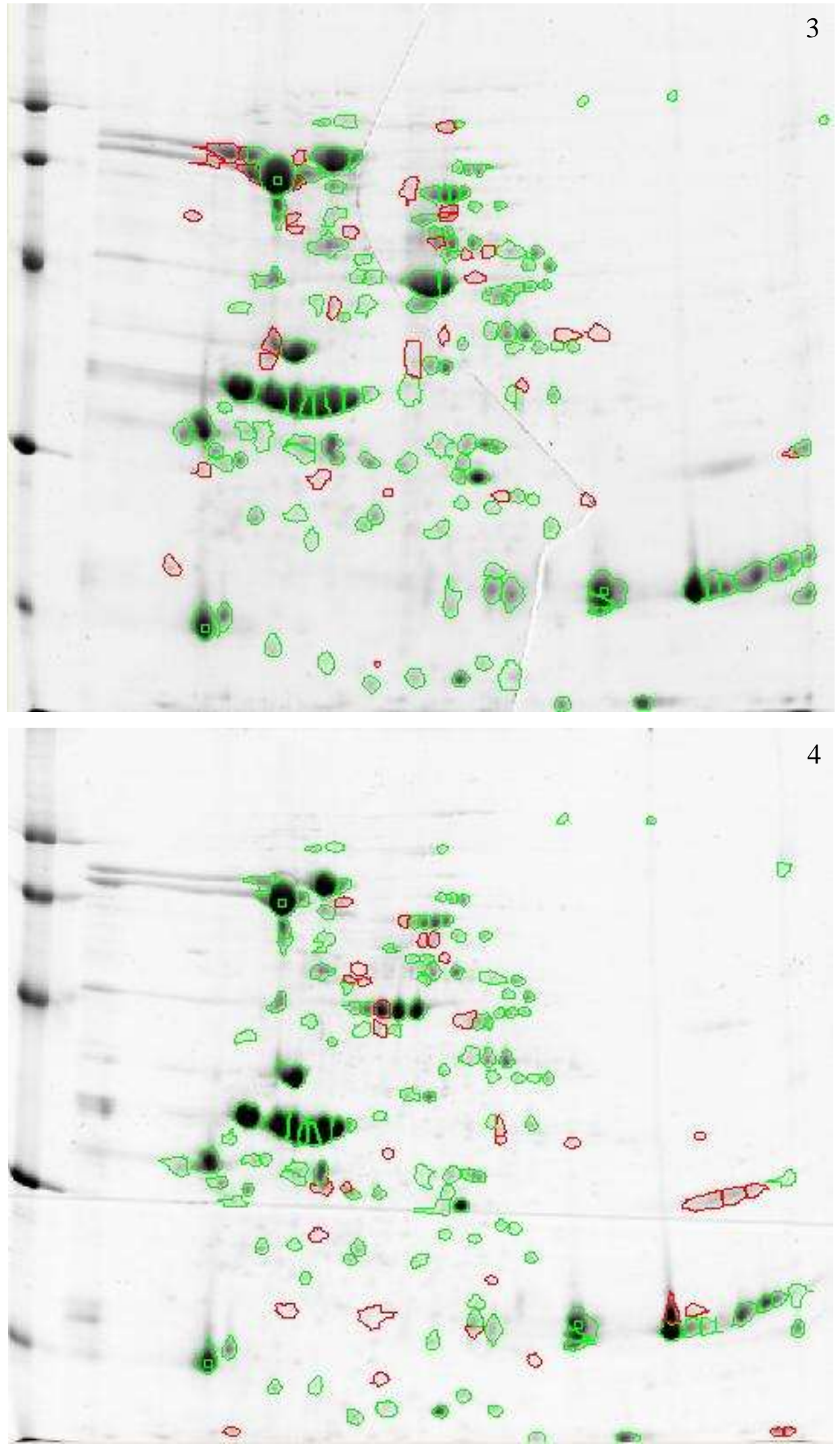

Figura 17: Matching entre a amostra convencional 3 e sua respectiva GM, amostra 4. Os spots que se sobrepuseram estão destacados em verde e os que não apresentaram sobreposição estão em vermelho. 


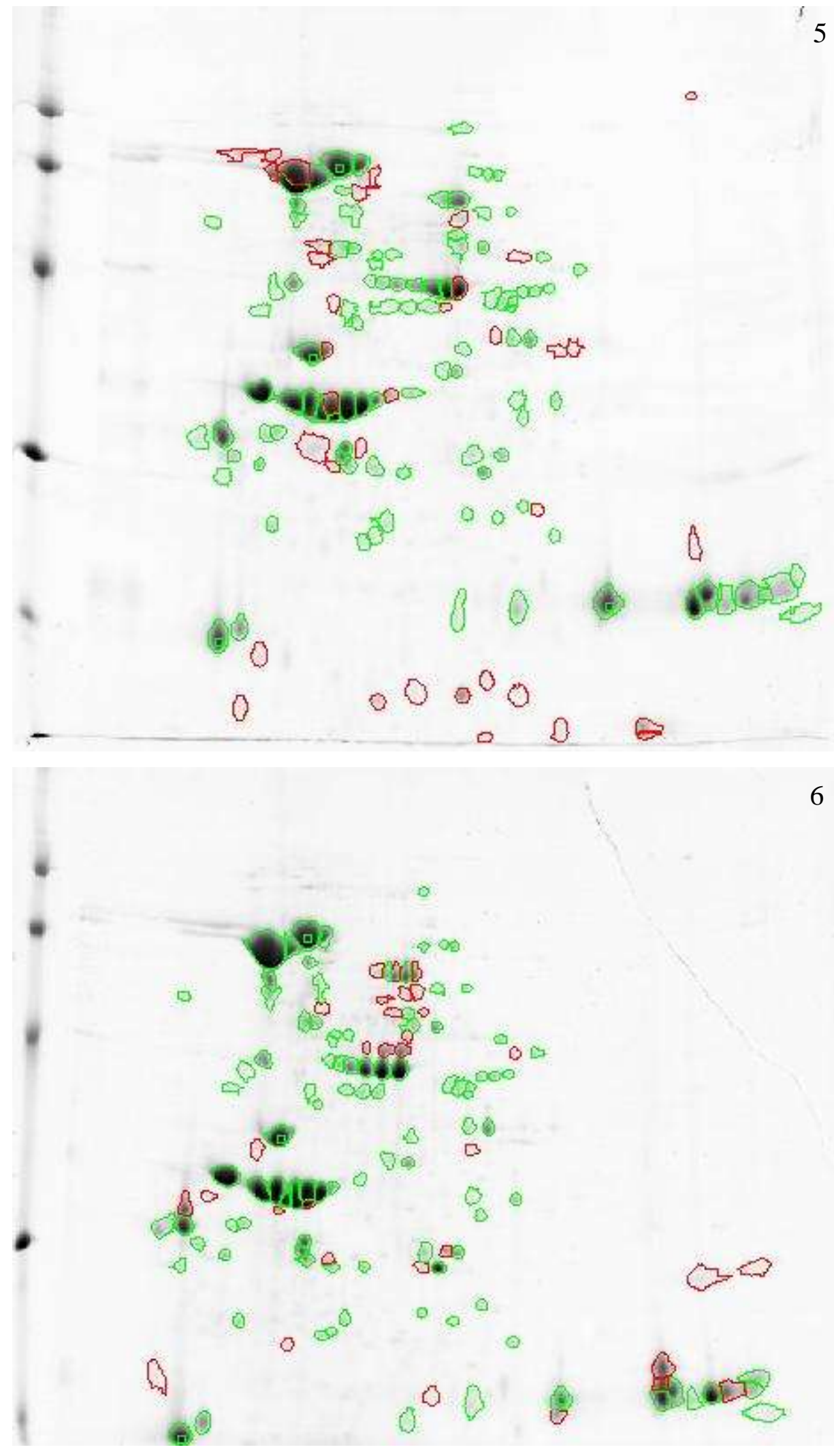

Figura 18: Matching entre a amostra convencional 5 e sua respectiva GM, amostra 6. Os spots que se sobrepuseram estão destacados em verde e os que não apresentaram sobreposição estão em vermelho. 


\subsection{Correlação entre os géis}

Os gráficos que estabelecem as correlações entre duas variáveis são importantes para os estudos que tem como objetivos encontrar possíveis mudanças na expressão de proteínas, reprodutibilidade entre réplicas de géis da mesma amostra, variações técnicas e também para avaliar a semelhança na distribuição das proteínas nos conjuntos de géis (BRANDÃO; BARBOSA; ARRUDA, 2010; BANDOW et al., 2008).

Com o gráfico de dispersão é possível analisar semelhanças entre os géis ou variações experimentais, como as disparidades de valores de intensidade e volume entre os spots correspondentes. Com este tipo de gráfico, cria-se uma dependência linear que relaciona os valores de um gel (eixo x) com o gel referência (eixo y) (GE Healthcare - User Manual).

Os gráficos de correlação são elaborados pelo programa a partir dos valores de matching. Com os gráficos conseguimos analisar a correlação entre as imagens dos géis das amostras genitoras e seus correspondentes GM. A Figura 19 representa os gráficos para a \% de intensidade e a Figura 20 representa os gráficos para a \% de volume. 

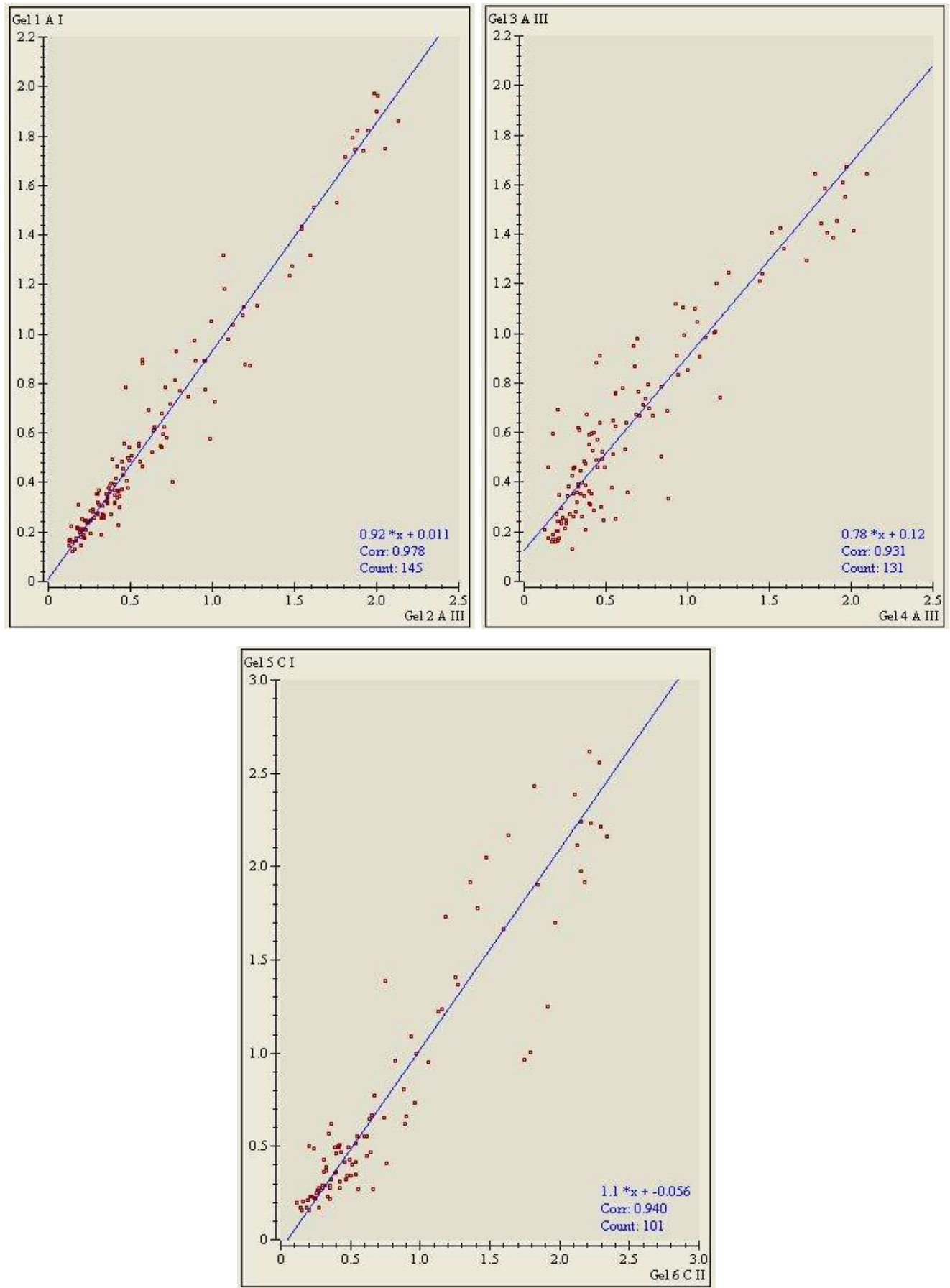

Figura 19: Gráficos de correlação da \% de intensidade entre a o gel referência da amostra genitora e o gel referência da sua correspondente GM. O primeiro compara amostra 1 e 2, o segundo compara 3 e 4, o terceiro compara amostra 5 e 6 . Corr é o coeficiente de correlação e count é o número de spots que apresentaram matching entre as amostras correlacionadas. 

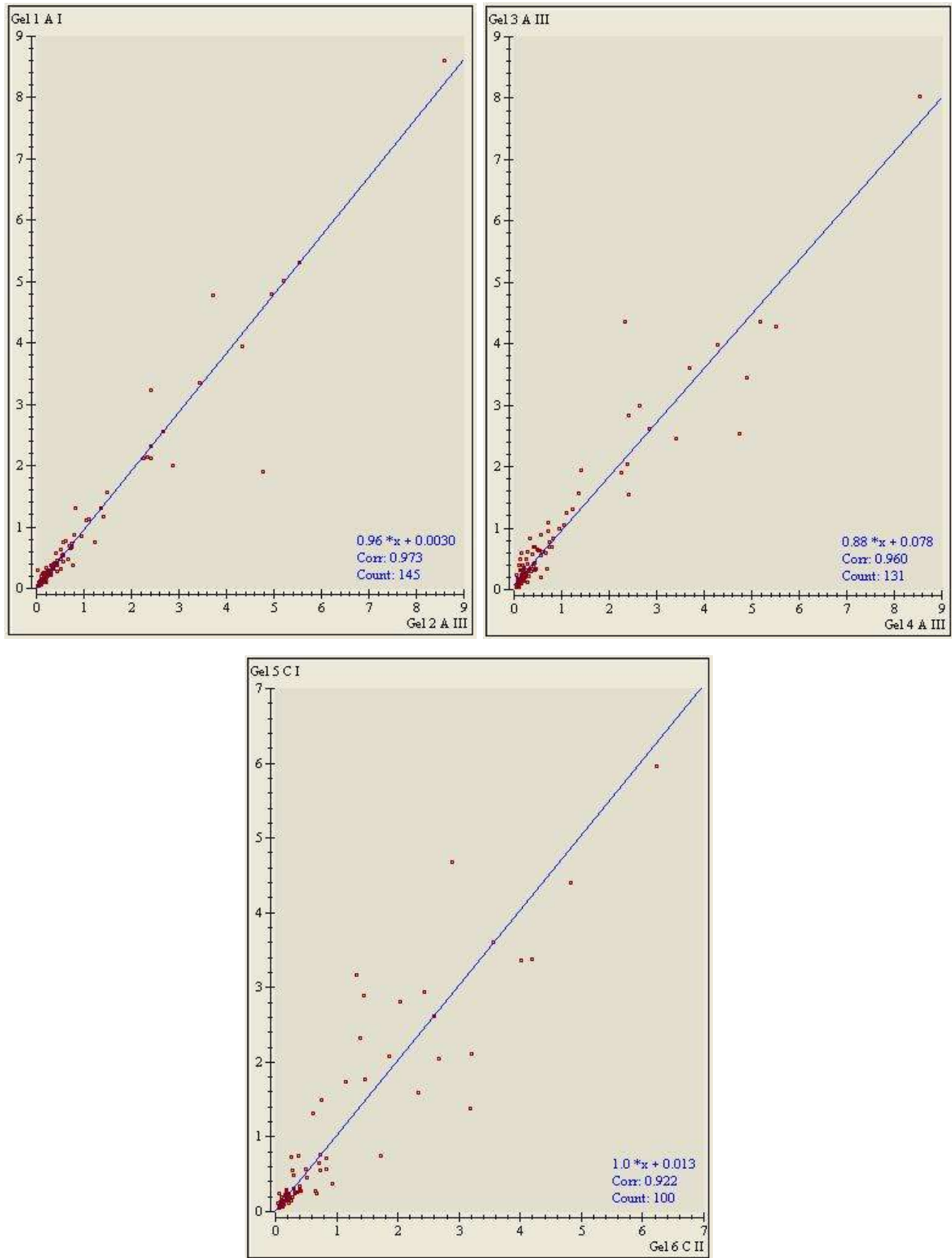

Figura 20: Gráficos de correlação da \% de volume entre a o gel referência da amostra genitora e o gel referência da sua correspondente GM. O primeiro compara amostra 1 e 2 , o segundo compara 3 e 4 , o terceiro compara amostra 5 e 6 . Corr é o coeficiente de correlação e count é o número de spots que apresentaram matching entre as amostras correlacionadas.

O gráfico gera o coeficiente de correlação, este quando elevado ao quadrado nos dá o coeficiente de determinação $\left(\mathrm{R}^{2}\right)$. $\mathrm{O} \mathrm{R}^{2}$ indica quanto da variância da variável resposta é explicada pela variância das variáveis explicativas. Seu valor está no intervalo de 0 a 1 : Quanto maior, mais explicativo é o modelo. Avaliamos a correlação entre as \% de 
intensidade e as \% de volumes. Consideramos um ótimo coeficiente de determinação quando estava entre 0,8 à 1 e bom entre 0,60 à 0,79 .

Para a \% de intensidade os $\mathrm{R}^{2}$ obtidos foram de $0,96,0,87$ e 0,88 e para $\%$ de volume os $\mathrm{R}^{2}$ obtidos foram de 0,95, 0,92 e 0,85 para as correlações entre as amostras 1 e 2, 3 e 4,5 e 6 respectivamente. Os coeficientes de determinação variaram dentro da faixa considerada ótima.

Não se encontram muitos trabalhos acadêmicos que envolvam as análises de imagens e suas correlações.

Brandão e colaboradores (2010) trabalharam com soja GM e não GM e consideram como ótimo $\mathrm{R}^{2}$ acima de 0,9 e atingiram apenas valores ótimos, porém deve-se observar que trabalharam com apenas duas amostras, sendo uma de cada.

Bandow e colaboradores (2008) realizaram um trabalho sem muitas similaridades com o presente, pois, tiveram como amostra proteínas plasmáticas, mas vale citá-lo, pois, avaliaram a variação técnica entre as imagens pelos coeficientes de correlação dos volumes (sem transformá-los em coeficientes de determinação $=\mathrm{R}^{2}$ ). Obtiveram valores que oscilam entre 0,95 e 0,99 garantindo a alta reprodutibilidade entre os géis.

Ao avaliar os coeficientes de correlação do presente trabalho, observamos que os valores variaram entre 0,98 a 0,93 para $\%$ de intensidade dos spots e 0,97 a 0,92 para a $\%$ de volume dos spots, consolidando a qualidade dos resultados obtidos.

\subsection{Orientação dos spots}

A observação da orientação dos spots em relação ao gel referência é uma análise válida para verificar possíveis alterações na corrida e se esta influenciou na formação do mapa protéico. Essas alterações podem acontecer por má polimerização do gel causando irregularidades e consequentemente tornando a migração dos peptídeos irregular; problemas de corrente e voltagem e ainda tempo de corrida (altera o quanto o peptídeo migra conforme seus PMs). Portanto, a orientação dos spots nos mostra a reprodutibilidade entre as amostras.

A verificação do alinhamento é realizado automaticamente a partir do software ImageMaster 2D Platinum versão 6.0 (GE Healthcare), comparando géis GM e genitoras com o gel definido como de referência de cada amostra. 

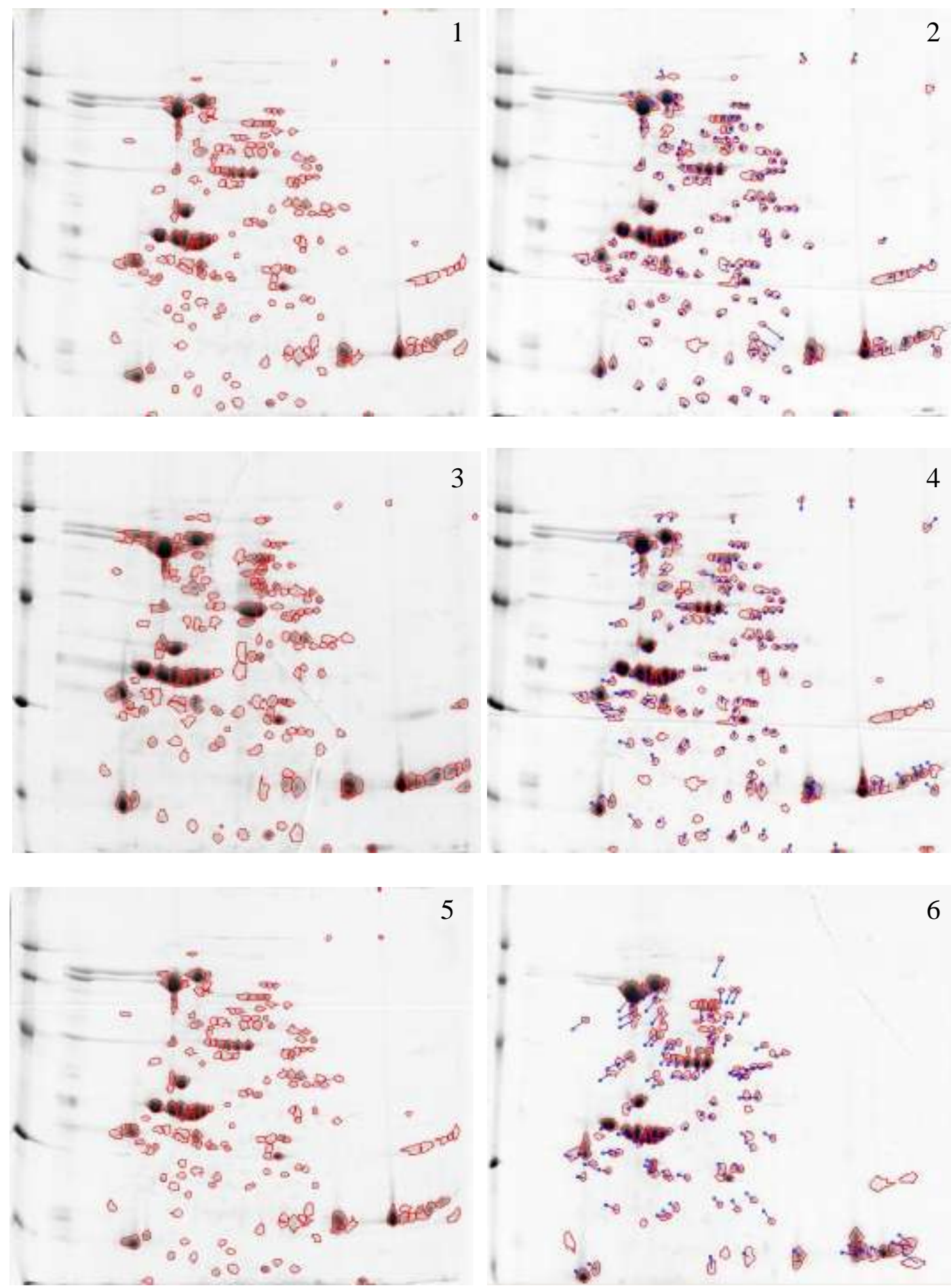

Figura 21: Orientação dos vetores em relação à localização dos spots. Comparação feita entre a amostra convencional (1, 3 e 5$)$ e suas respectivas isolinhas GM (2, 4 e 6$)$.

A reprodutibilidade entre as amostras mostrou-se adequada, com a orientação de praticamente todos os spots para o mesmo sentido, não sendo observadas distorções que tenham alterado a migração peptídica. As alterações que foram percebidas são justificadas pela laboriosa técnica que contém muitas variáveis e etapas. 
Para avaliar as possíveis alterações dos mapas protéicos entre amostras convencionais e GMs, também consideramos que estas poderiam ser perceptíveis em outras fases de amadurecimento do grão. Para isso, fizemos extrações protéicas das vagens das amostras de soja que estavam em semanas anteriores de amadurecimento (Anexos).

Mesmo dentro de um grão, um grande número de proteínas específicas podem existir ou serem regulados diferentemente em várias fases de desenvolvimento (NOZU; TSUGITA; KAMIJO, 2006). As análises bioquímicas e fisiológicas fornecem melhor compreensão do desenvolvimento, mas, infelizmente, não fornecem informações sobre a genética e expressão das proteínas nas diferentes fases do vegetal. Como a proteômica tem se mostrado eficiente para informar as diferenciações proteícas durante o desenvolvimento, tanto para grãos, quanto para folhas e flores (AHSAN et al., 2009), seria possível identificar o mecanismo pelo qual ocorre a deposição das proteínas da fração ácida da glicinina, caso tivéssemos acompanhado todas as fases de desenvolvimento das vagens até a maturação completa das sementes.

Encontram-se muitos trabalhos que comparam as transformações proteícas ao longo do desenvolvimento da planta ao nível foliar, floral e raizes como os trabalhos de Ahsan e colaboradores (2009), Staswick (1989) e Lim et al., (2010), porém, trabalhos que avaliam o desenvolvimento das proteínas das sementes são praticamente inexistentes.

Estima-se que 6-15\% das proteínas das folhas na floração, posteriormente são discriminadas e os metabótitos e aminoácidos resultantes são exportados para o desenvolvimento das sementes através do sistema de floema. As sementes também exigem um grande aporte de nitrogênio e outros nutrientes para suportar o elevado nível de síntese protéica que ocorre durante seu desenvolvimento, para isso ocorre uma significativa mobilização de nitrogênio dos tecidos vegetativos (STASWICK; HERMODSON; NIELSEN, 1989). 


\subsection{Imagens em terceira dimensão}

A partir das análises do software ImageMaster 2D Platinum é possível obter imagens tridimensionais dos picos dos spots. Esse tipo de análise nos ajuda a comparar a intensidade de expressão de determinado grupo protéico quando comparado em diferentes géis de diferentes amostras.

É possível verificar grande analogia nas imagens 3D dos picos dos spots selecionados. A pouca variabilidade que se percebe pode ser justificada pela técnica que apresenta inúmeras variáveis, como alterações na polimerização dos géis fazendo com que os spots se desloquem mais ou menos no gel, diferenças de corrente entre corridas distintas, entre outras.

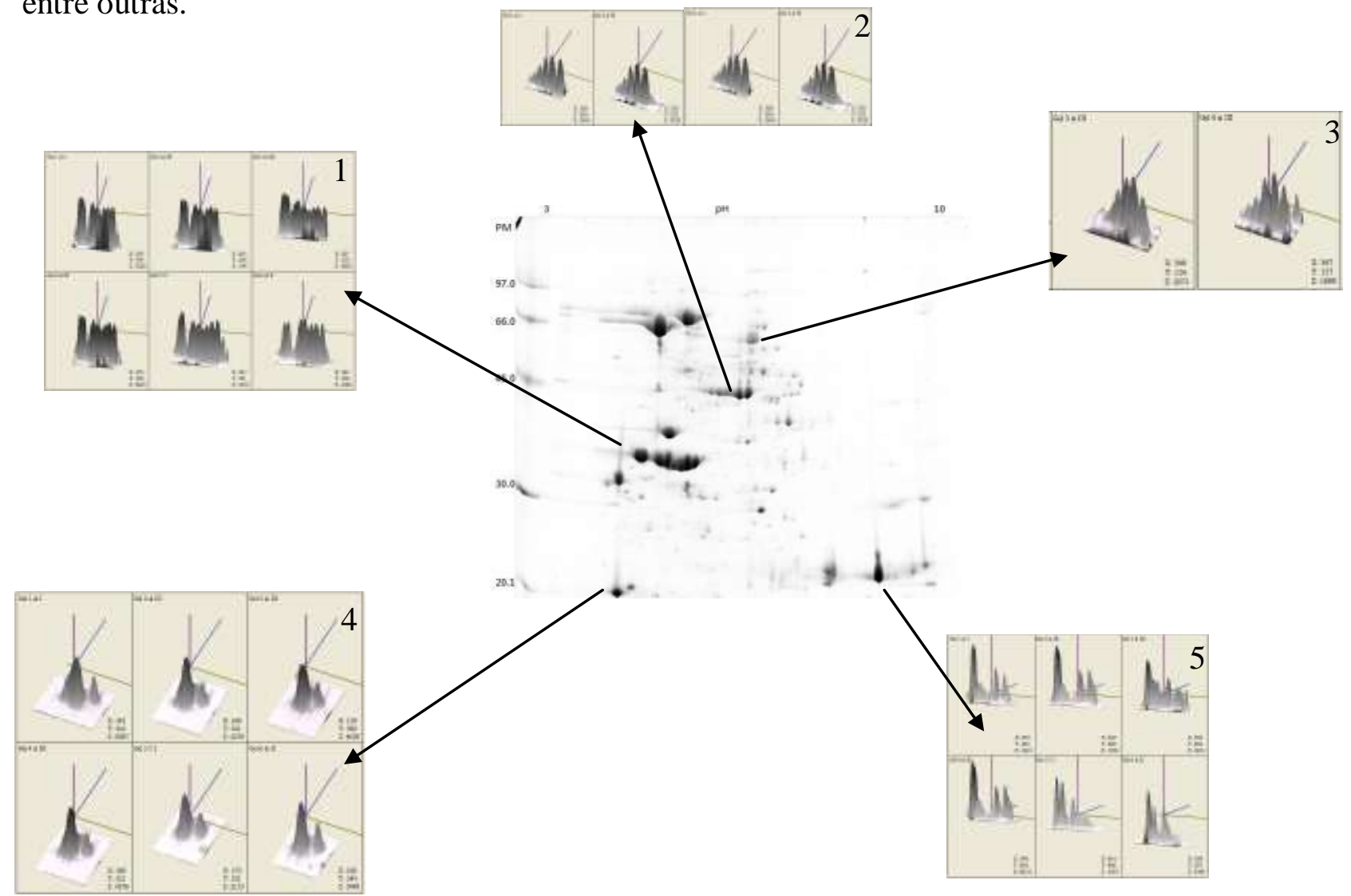

Figura 22: Imagem tridimensional (3D) dos picos de alguns dos principais grupos protéicos da soja, gerados a partir de géis bidimensionais de referência de cada amostra. Em 1: Imagem 3D do spots correspondente à porção da fração ácida de Glicinina em todas as amostras; em 2: Imagem 3D do spots correspondente à Fração $\beta$ da $\beta$-conglicinina nas amostras 1 e 2; em 3: Proteína ligante de sacarose na amostra 3 e 4; em 4: Imagem 3D do spots correspondente ao Inibidor de Tripsina Kunitz em todas as amostras; em 5: Porção da fração básica de Glicinina em todas as amostras. 


\subsection{Eletroforese bidimensional de amostras orgânicas}

Com o intuito de verificar alterações nos principais grupos protéicos, assim como nos fatores antinutricionais e inibidores de proteases, realizamos as mesmas análises com amostras orgânicas de soja comparativamente com as demais amostras GM e convencionais,.

Primeiramente, vale salientar, que entre as amostras orgânicas, a denominada como amostra 2 orgânica, apresentava entre os grãos normais, cerca de 7,5\% de grãos escuros e enrugados, que entre os agricultores são conhecidos como grãos "ardidos". As sementes ardidas são grãos ou partes de grãos que pela ação do calor e/ou umidade, apresenta-se visivelmente fermentados com coloração marrom ou escura na casca e interiormente (BRASIL, 1983).

Para as análises, as sementes ardidas foram removidas da amostra. Essa seleção não foi necessária para as outras amostras, tanto convencionais, quanto GMs e a amostra 1 orgânica.

Após a edição manual e com o auxílio da ferramenta de detecção de spots do programa ImageMaster 2D Platinum obteve-se o número de spots de cada gel e suas respectivas extração, como pode ser observado na Tabela 8. Foram utilizados os mesmos parâmetros de smooth, área mínima e saliência para a detecção dos spots das amostras orgânicas.

Tabela 8: Número de spots detectados pelo software ImageMaster 2D Platinum para as diferentes amostras orgânicas e suas respectivas extrações e triplicatas em géis de acrilamida $12 \%$, gradiente de $\mathrm{pH} 3-10$.

\begin{tabular}{llll}
\hline Amostra & \multicolumn{1}{c}{$\begin{array}{c}\text { Número de } \\
\text { spots }\end{array}$} & Amostras & $\begin{array}{c}\text { Número de } \\
\text { spots }\end{array}$ \\
\hline 1 A I & 123 & 2 A I & 185 \\
1 A II & 103 & 2 A II & 177 \\
1 A III & 107 & 2 A III & 143 \\
1 B I & 137 & 2 B I & 147 \\
1 B II & 137 & 2 B II & 162 \\
1 B III & 129 & 2 B III & 124 \\
1 C I & 96 & 2 C I & 161 \\
1 C II & 114 & 2 C II & 141 \\
1 C III & 111 & 2 C III & 135 \\
\hline MÉDIA & $\mathbf{1 1 7 , 4}$ & MÉDIA & $\mathbf{1 5 2 , 8}$ \\
\hline
\end{tabular}


Os valores médios do número de spots encontrados para as amostras orgânicas foram significativamente diferentes entre eles para um $\mathrm{p}$-valor $=0,0006$.

Ao comparar o número de spots encontrados nos diferentes tipos de cultivo, verificamos que não existem diferenças significativas (p-valor=0,2429). A Figura 23 representa o número de spots encontrados nos 3 tipos de cultivo.

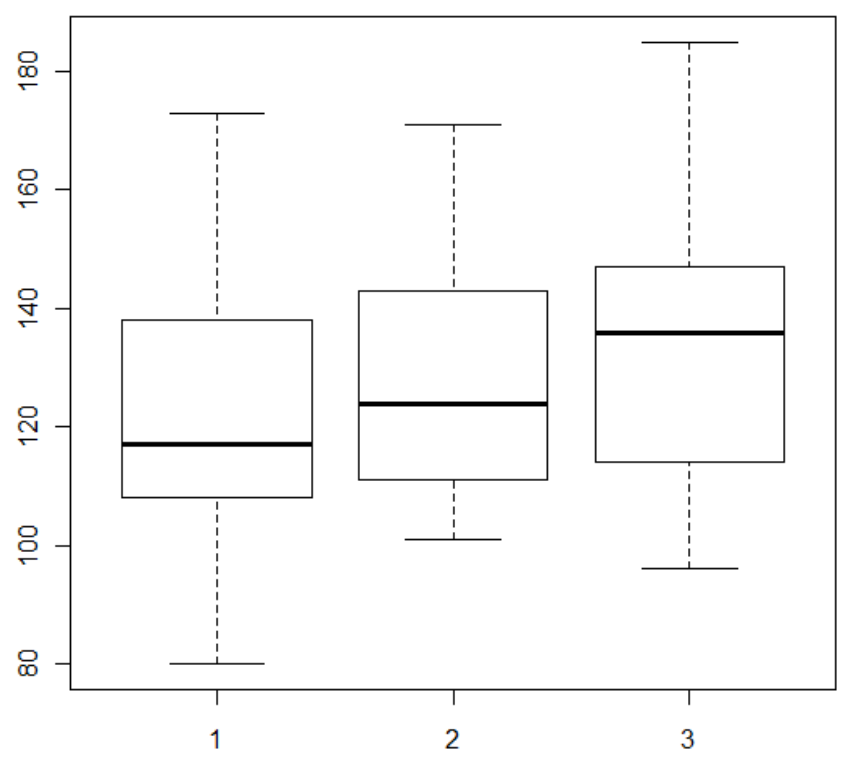

Figura 23: Gráfico representativo da variação do número de spots nos diferentes tipos de cultivo. Não houve diferenças para o nível de significância de 5\%. Número 1 são as amostras convencionais, 2 amostras GMs e 3 amostras orgânicas.

Ao verificar se pelo menos uma amostra (entre convencionais, GMs e orgânicas) diferencia das demais, aplicamos ANOVA e como foi significativo aplicamos comparações múltiplas para a verificação de qual amostra que diferencia. Ao aplicar o teste de Tukey verificamos que há diferenças significativas. O número de spots encontrados para as amostras 3 e 5 convencionais e 1 orgânica são significativamente menores que os encontrados na amostra 2 orgânica, como está representado na Figura 24. 


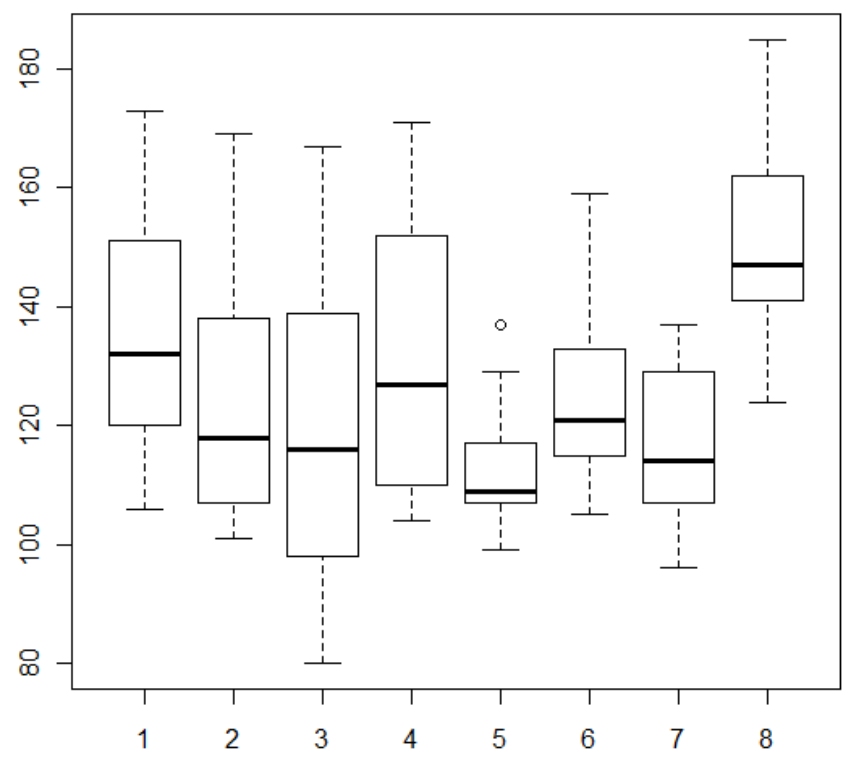

Figura 24: Gráfico representativo da variação do número de spots nos diferentes amostras. Número 1, 3 e 5 são as amostras convencionais, 2, 4 e 6 amostras GMs e 7 e 8 amostras orgânicas. Houve diferenças significativas, a amostra 8 apresentou mais spots que as amostras 3, 5, 7.

Assim como realizamos o processo de matching entre os géis das amostras de soja GMs e convencionais, realizamos também para os géis das sojas orgânicas, usando as mesmas referências, ou landmarks. Avaliamos a sobreposição entre as triplicatas, entre as extrações (Tabela 9) e entre as amostras (Tabela 10).

$\mathrm{Na}$ amostra 1 orgânica, na análise da sobreposição das triplicatas, obtiveram-se resultados inferiores aos encontrados para amostras convencionais e GM. Na extração A e B, os valores inferiores da sobreposição das triplicatas foram de $69,2 \%$ e $62,0 \%$. Os valores estão levemente diminuídos dos demais resultados (tanto para amostras convencionais, GM e as demais orgânicas). Porém fogem do padrão adotado como satisfatório nas nossas análises, que foi estipulado com base nos dados da literatura.

Tanto para a sobreposição entre as extrações (Tabela 9) e entre as duas amostras orgânicas (Tabela 10) verificaram-se matchings superiores a 70\%, conforme o aguardado para essa análise. Esses resultados corroboram com os resultados encontrados para as amostras GM e convencionais, anteriormente descritas e também com dados da literatura para GMs e convencionais (BRANDÃO; BARBOSA; ARRUDA, 2010; CASTRO, 2009). Na figura 25 
estão expostos os géis referência de cada amostra orgânica, justapostos para a verificação da $\%$ de matching.

Tabela 9: Spots comuns entre as extrações das amostras orgânicas em relação ao gel referência.

\begin{tabular}{lccc}
\hline Amostra & Extração referência & $\mathbf{N}^{\mathbf{0}}$ de spots comuns & \% de matching \\
\hline 1 & 1 A I & 86 & 74,6 \\
& 1 B II & 89 & 73,6 \\
\hline 2 & 2 A I & 121 & 72,0 \\
& 2 C II & 110 & 72,1 \\
\hline
\end{tabular}

Tabela 10: Spots comuns entre as diferentes amostras de soja orgânica. Sobreposição dos géis referência de cada amostra (1 A II e 2 C III).

\begin{tabular}{ccc}
\hline Amostras & $\mathbf{N}^{\mathbf{0}}$ de spots comuns & \% de matching \\
\hline 1 e 2 & 88 & 72,1 \\
\hline
\end{tabular}

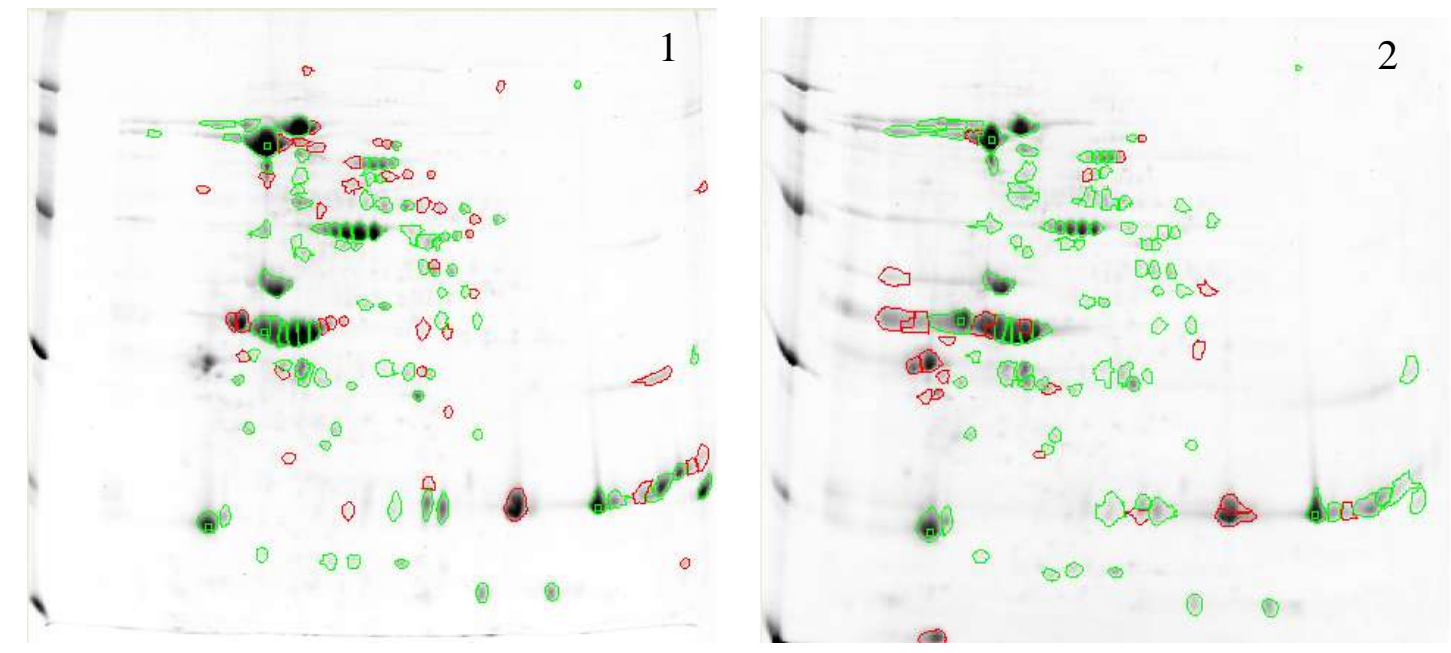

Figura 25: Géis bidimensionais das amostras orgânicas, representando a sobreposição entre elas. A imagem 1 corresponde a amostra 1 A II e a imagem 2 corresponde a amostra 2 C III. A amostra 1 é a referência. Os spots que se sobrepuseram estão destacados em verde e os que não apresentaram sobreposição estão em vermelho.

Muitos trabalhos a respeito das culturas orgânicas estão disponíveis na literatura acadêmica. Alguns descrevem características positivas de produção (PADOVAN et al., 2002), sobre qualidade nutricional (ARBOS et al., 2010 ${ }^{\mathrm{A}}$; ARBOS et al., 2010 ${ }^{\mathrm{B}}$; DANGOUR et al., 2009; HOEFKENS et al., 2010) e ainda, comparações entre as diferentes formas de cultivo, 
ou seja, entre as culturas orgânicas, convencionais e GMs sobre diferentes aspectos (LIMA; VIANELLO, 2011; AZADI; HO, 2010). Mesmo com tantos trabalhos acadêmicos sobre as culturas orgânicas, não se encontram análises proteômicas destes e, por conseguinte, houve dificuldade de comparação destes resultados com a literatura.

Deve-se mencionar que, embora as quantidades de proteínas das amostras submetidas à eletroforese 2D tenham sido idênticas, os géis de amostras orgânicas, GMs e suas genitoras revelaram diferenças nas quantidades de spots detectados.

\subsection{Hipóteses de alterações não resultantes da transgenia}

No desenvolvimento deste trabalho, exploramos principalmente a comparação entre as linhagens de soja geneticamente modificadas com suas estirpes genitoras, a fim de detectar alterações entre elas na tentativa de elucidar questões referentes as inocuidade alimentar pelo advento da transgenia.

Neste trabalho, assim como em outros já realizados em nosso laboratório (CASTRO, 2009), perceberam-se pequenas alterações não significativas entre a expressão dos proteomas GMs e não GMs.

No trabalho de Castro (2009), detectou-se alteração em apenas um spot, expresso em maior concentração nas amostras GMs. Este, por espectrometria de massas foi identificado como a proteína precursora da subunidade G4 glicinina, conseqüentemente, concluiu-se que as diferenças não comprometem a inocuidade alimentar das amostras de soja GMs em relação a suas respectivas variedades genitoras. Porém, na ocasião, argumentou-se que para o esclarecimento de tais alterações, novos estudos com amostras cultivadas na mesma lavoura deveriam ser realizados, já que as amostras de Castro foram cultivadas em diferentes locais, embora na mesma região no sul do Estado de Goiás.

No presente trabalho, as alterações em função dos distintos locais de cultivo foram eliminadas, pois, todas as amostras foram cultivadas na Embrapa Soja - Londrina. Na tentativa de elucidar o motivo das tais sutis diferenças também presentes neste trabalho, elaboramos duas estratégias;

- Comparações entre os cultivares convencionais;

- Comparações entre diferentes formas de cultivo (convencionais, GMs e orgânicos); 


\subsubsection{Comparação entre os cultivares convencionais}

A fim de aclarar se as pequenas variações encontradas nas comparações entre os géis das amostras GMs e convencionais são adventos das variações naturais das espécies ou devido a transformações genéticas ocorridas como consequência da transgenia, decidimos realizar comparações entre as próprias amostras convencionais. Para isso verificamos a sobreposição entre os géis referência de cada amostra (Figura 26).

Tabela 11: Tabela representativa da variabilidade natural existente entre as amostras. A amostra 3, representa o gel referência, pois, apresentou maior número de spots detectados.

\begin{tabular}{lcc}
\hline & Número de matchs & \% de matching \\
\hline Amostra 1 & 103 & 68,6 \\
Amostra 5 & 126 & 75,0 \\
\hline
\end{tabular}

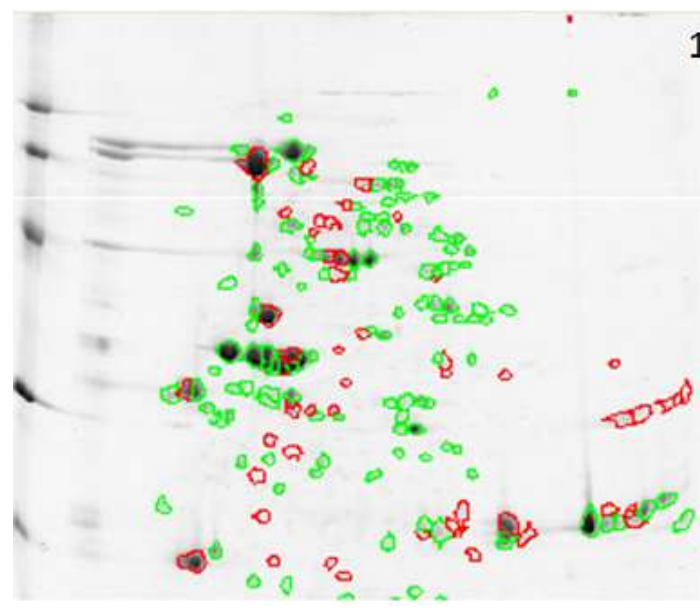

1

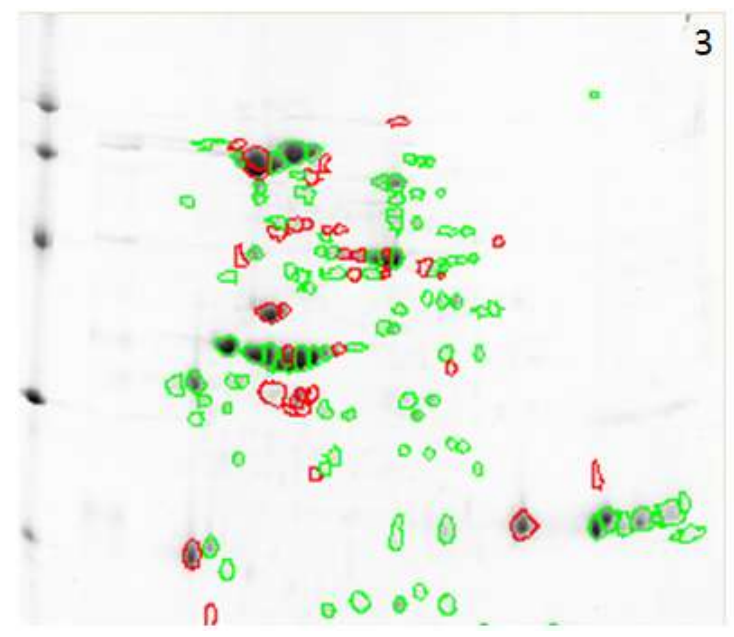

Figura 26: Imagens 1, 2 e 3 corresponde a sobreposição dos géis de referência das amostras convencionais 1, 3 e 5 respectivamente. Os matchings representam a variabilidade natural existente entre as amostras. O gel 2, representa a amostra 3 e é o gel de referência, por apresentar maior número de spots detectados. 
Em um julgamento preliminar, no qual analisamos a presença e ausência dos grandes grupos protéicos, fica evidente a similaridade entre as amostras convencionais. Porém, quando submetemos as mesmas às sobreposições com seus géis de referência, percebemos que estas variam tanto quanto as amostras GMs com suas respectivas amostras convencionais.

Nos matchings entre as amostras GMs e suas respectivas convencionais, obtemos as seguintes porcentagens de sobreposição: 87,1, 79,6 e 74,8 para as amostras 1 e 2, 3 e 4 e 5 e 6 respectivamente. Já na sobreposição dos géis convencionais, o maior valor obtido foi de $75 \%$ (Tabela 11).

Esses resultados corroboram com a idéia de que as variações encontradas entre as amostras GMs e suas estirpes genitoras são consequência das diferenças naturais que ocorrem nas plantas, nas mesmas condições ambientais e de cultivos, como é o caso das amostras coletadas para este trabalho.

Castro (2009) obteve valores de sobreposição entre as amostras GMs e as suas estirpes convencionais com magnitudes superiores a $70 \%$, porém, como já citado, suas amostras foram cultivadas em diferentes locais da mesma região e consequentemente possíveis condições desiguais de clima, solo, etc. Levantou-se a discussão sobre a origem dessas diferenças, se advinham das distintas condições de cultivo, ou meramente pela variabilidade natural das plantas.

Zolla e colaboradores (2007) utilizaram as ferramentas proteômicas para facilitar a detecção de efeitos não intencionais causados pela manipulação do gene de milho por bombardeamento. Com uma ampla comparação entre as expressões aumentada ou diminuída de spots nas amostras GM e não GMs, perceberam mais alterações entre as mesmas amostras transgênicas quando sofreram variações ambientais por terem sido cultivadas em locais distintos, que quando se comparou amostras que sofreram diferenciação por inserção de genes com amostras sem essa inserção.

$\mathrm{O}$ ambiente mostrou-se mais influente nos perfis proteômicos que o bombardeamento de partículas. Os autores defendem que as alterações que ocorrem devido à transgenia, também são vistas na natureza, com nos cruzamentos tradicionais, hibridizações, recombinação genética natural, rearranjos cromossômicos naturais, fusões celulares, etc (ZOLLA et al., 2007).

A compreensão da variabilidade natural do proteoma é crucial para a interpretação das diferenças biológicas e relevantes para a segurança entre transgênicos e linhas genitoras não transgênicas (TESHIMA; NAKAMURA; SATOH, 2010). 
Mesmo quando o objeto de estudo não é a soja, resultados indicativos de variabilidade natural entre as plantas são obtidos. Em um recente estudo, explorou-se a analise proteômica e técnicas sorológicas para a elucidação de possíveis proteínas alergênicas e alérgenos conhecidos de amostras e arroz GM e convencional. Os autores concluíram através de seus resultados que não houve variações significativas entre as amostras GMs e não GMs de arroz e as pequenas variações, mesmo não significativas, não parecem ser alteradas por fatores de modificações genéticas e sim pela diferenciada expressão da natureza (SATOH et al., 2011).

Teshima e colaboradores (2010) compararam a variação natural entre dez cultivares de arroz com distintas origens genéticas com o uso de técnicas proteômicas. Entre as seis cultivares japonesas as diferenças de expressão foram pequenas, porém, quando comparadas com cultivares de outros países, como Índia e Tailândia, as diferenças foram superiores. Os autores, mesmo não trabalhando com a elucidação da segurança dos alimentos geneticamente modificados, apontam esta variabilidade encontrada como um dado útil na elucidação das pequenas alterações encontradas nos ensaios proteômicos entre GMs e não GMs (TESHIMA; NAKAMURA; SATOH, 2010).

A avaliação comparativa deve considerar a extensão da variação natural e não simplesmente comparar as linhas geneticamente modificadas contra as convencionais. Para isso, ao avaliar estirpes GMs e não GMs de batata, Lehesranta e colaboradores (2005), também compararam as amostras convencionais entre si. Detectaram que as variações ocorridas entre as amostras GMs e seus controles não GMs foram menores que as alterações encontradas entre diferentes variedades convencionais (LEHESRANTA et al., 2005). 


\subsubsection{Comparação entre diferentes formas de cultivo}

As diferentes formas de cultivo geram opiniões distintas entre os consumidores interessados em benefícios a saúde, ou ainda, diminuição dos riscos causados por elementos externos advindos da dieta. Na tentativa de elucidar se a forma de cultivo influencia na inocuidade dos alimentos, comparamos sobre os aspectos proteômicos culturas GMs, suas estirpes genitoras e orgânicas. Para tais análises, consideramos a amostra convencional como a amostra referência por se tratar da cultura reconhecida como inócua para a saúde do consumidor e liberada para consumo pelos órgãos competentes como Codex alimentarius e Organização Mundial da Saúde.

A escolha da amostra orgânica utilizada na comparação com a dupla GM e sua estirpe parental foi em função da maior \% de matching, já que possuíamos duas amostras orgânicas distintas e estas não correspondem às amostras genitoras em questão. Mas para assegurar que as diferenças encontradas nas sobreposições não são em função da diferente amostra orgânica usada na comparação, nos garantimos usando duas amostras, porém, ilustramos nas Tabelas apenas os maiores valores de \% matching. Portanto, entre as amostras 1, 2, 3 e 4 GMs e convencionais, a amostra 2 orgânica apresentou maiores similaridades, enquanto que entre as amostras 4 e 5 , a amostra 1 orgânica foi mais similar.

Nas Tabelas 12, 13 e 14 estão expostas as \% se sobreposição entre as diferentes amostras e formas de cultivo. As figuras 27, 28 e 29 ilustram tais sobreposições. 
Tabela 12: Número de spots comuns e \% de matching entre os diferentes tipos de cultivos. Comparou-se gel referencia da amostra convencional 1, gel referência da amostra GM 2 e gel referência da amostra orgânica 2.

\begin{tabular}{ccc}
\hline Amostra & Número de spots comuns & \% de matching \\
\hline 1 convencional e 2 GM & 145 & 87,1 \\
1 convencional e 2 orgânica & 104 & 64,4 \\
\hline
\end{tabular}

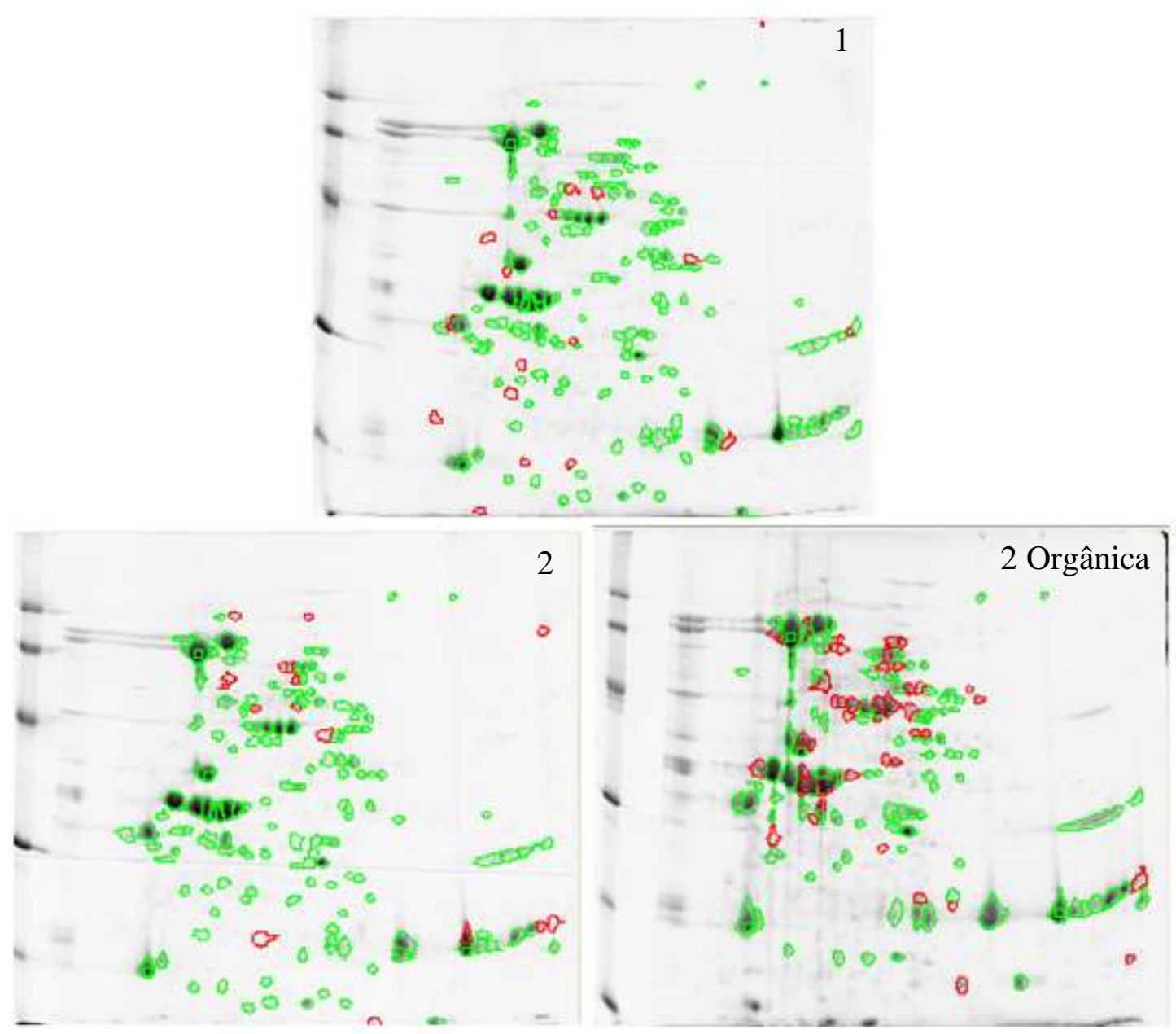

Figura 27: Imagens 1, 2 e 2 Orgânica correspondem a sobreposição dos géis de referência das amostras convencionais 1, GM 2 e orgânica 2 respectivamente. Os matchings representam a sobreposição entre as amostras, sendo que os spots que se sobrepuseram estão na cor verde e os spots que não se sobrepuseram estão na cor vermelha. 
Tabela 13: Número de spots comuns e $\%$ de matching entre os diferentes tipos de cultivos. Comparou-se gel referencia da amostra convencional 3, gel referência da amostra GM 4 e gel referência da amostra orgânica 2.

\begin{tabular}{ccc}
\hline Amostra & Número de spots comuns & \% de matching \\
\hline 3 convencional e 4 GM & 131 & 79,6 \\
3 convencional e 2 orgânica & 111 & 68,9 \\
\hline
\end{tabular}

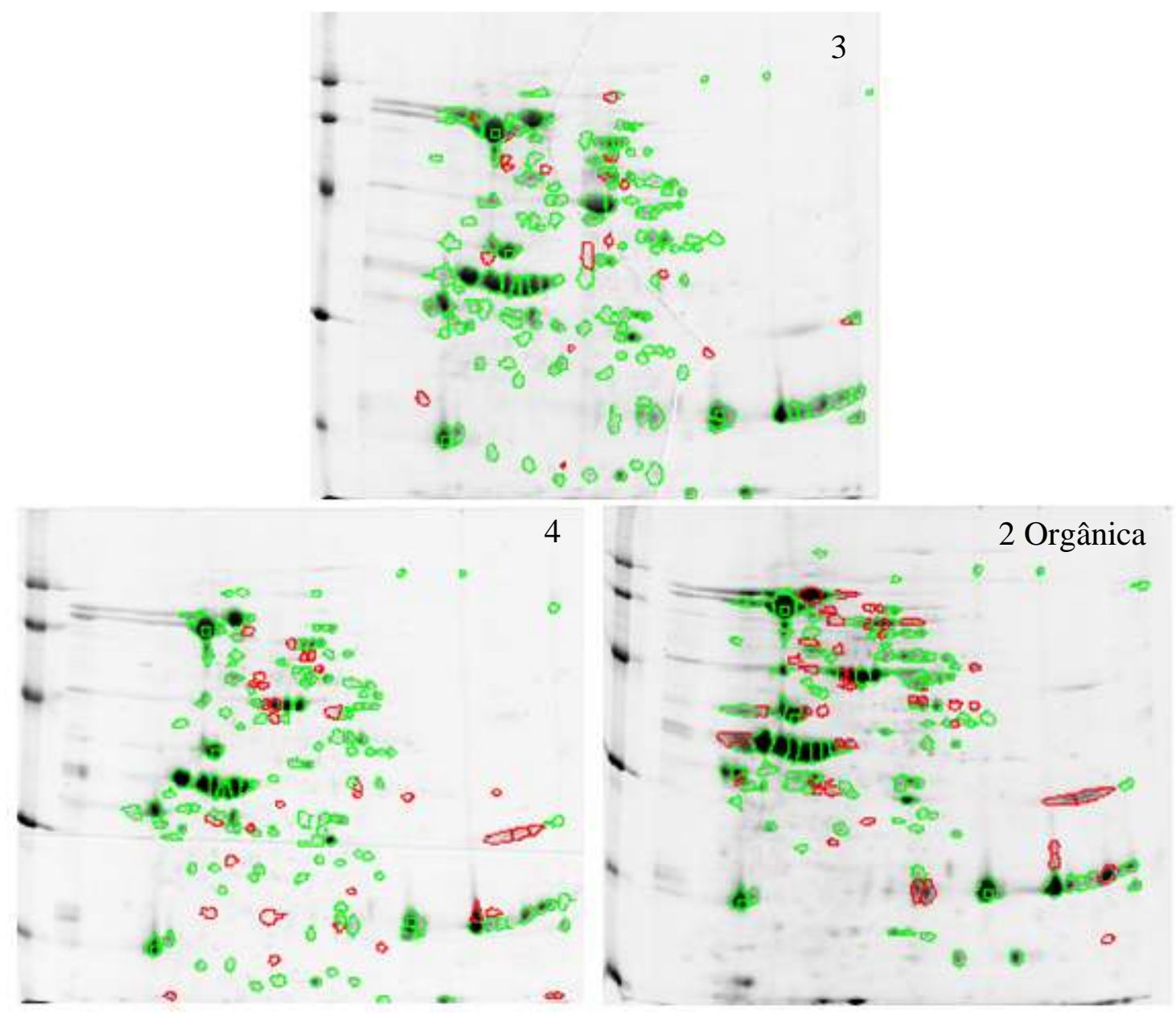

Figura 28: Imagens 3, 4 e 2 Orgânica correspondem a sobreposição dos géis de referência das amostras convencionais 3, GM 4 e orgânica 2 respectivamente. Os matchings representam a sobreposição entre as amostras, sendo que os spots que se sobrepuseram estão na cor verde e os spots que não se sobrepuseram estão na cor vermelha. 
Tabela 14: Número de spots comuns e \% de matching entre os diferentes tipos de cultivos. Comparou-se gel referencia da amostra convencional 5, gel referência da amostra GM 6 e gel referência da amostra orgânica 1.

\begin{tabular}{lcc}
\hline \multicolumn{1}{c}{ Amostra } & Número de spots comuns & \% de matching \\
\hline 5 convencional e 6 GM & 101 & 74,8 \\
5 convencional e 1 orgânica & 84 & 68,3 \\
\hline
\end{tabular}

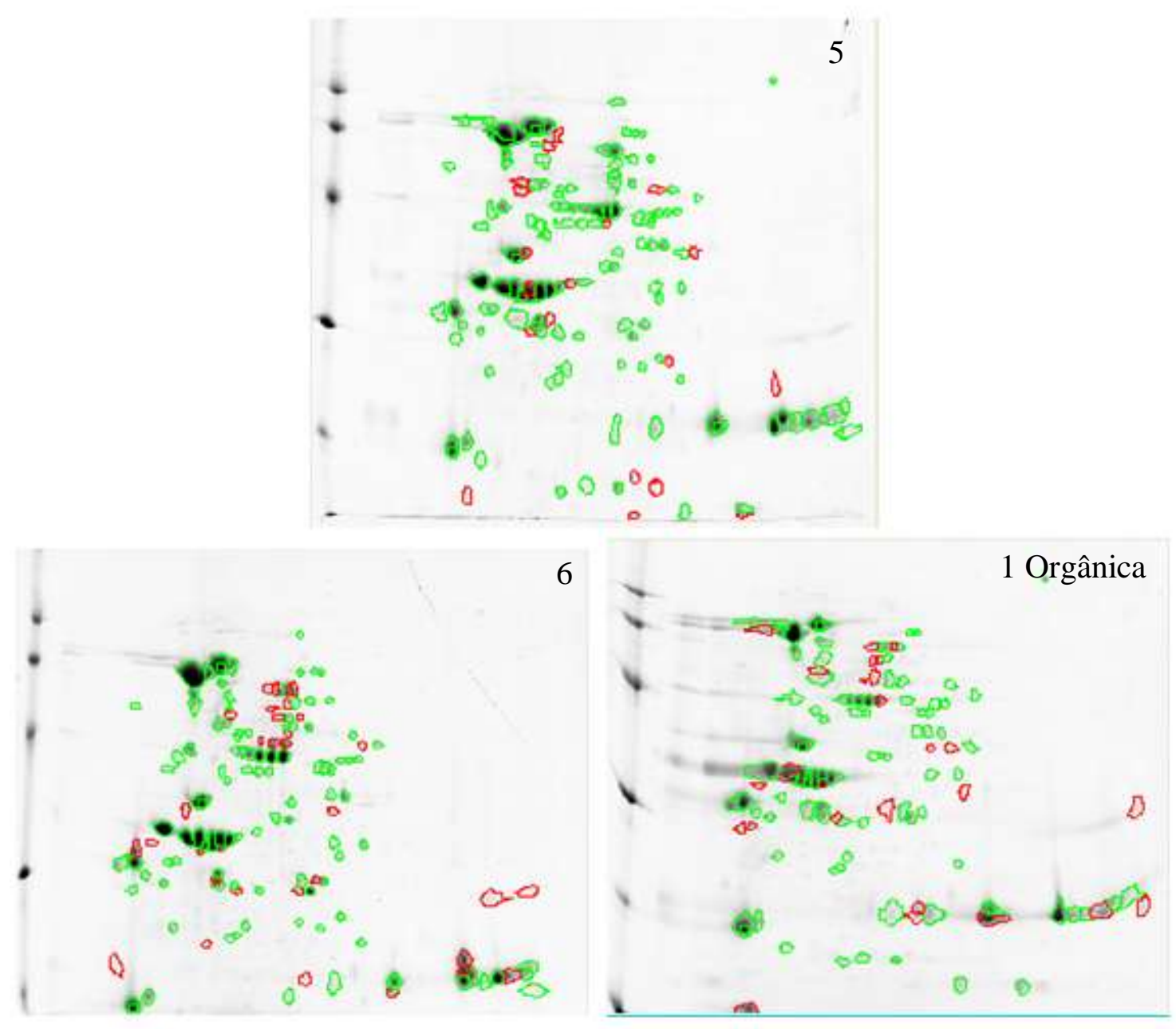

Figura 29: Imagens 5, 6 e 1 Orgânica correspondem a sobreposição dos géis de referência das amostras convencionais 5, GM 6 e orgânica 1 respectivamente. Os matchings representam a sobreposição entre as amostras, sendo que os spots que se sobrepuseram estão na cor verde e os spots que não se sobrepuseram estão na cor vermelha.

Segundo as Tabelas 12, 13 e 14, podemos perceber que as diferenças na sobreposição das amostras GM com suas estirpes genitoras foram menores que as diferenças encontradas entre a convencional e a orgânica. Nas diferenças entre GM e convencional 
encontramos os valores de 87,1, 79,6 e 74,8 enquanto que para as sobreposições entre convencionais e orgânicas, encontramos os valores de 64,4, 68,9 e 68,3. Portanto, podemos concluir que as diferenças encontradas entre as orgânicas são maiores que as encontradas entre GM e convencional ( $\mathrm{p}$-valor = 0,0259).

As diferenças encontradas entre as amostras convencionais e orgânicas são ligeiramente maiores do que as estipuladas anteriormente como ideais no nosso trabalho, que são \% de matchings superiores a 70. Esses valores são alcançados nas sobreposições entre GMs e suas estirpes genitoras.

Com esta análise é difícil afiançar que um tipo de cultivo é mais ou menos inócuo, porém, as tão discutidas e julgadas diferenças encontradas nas amostras GMs são mascaradas por se detectar que o cultivo orgânico, que apresenta um amplo respaldo de alimento saudável, apresenta tais diferenças e até em maior expressão.

As culturas convencionais, por ter um uso tradicional, são consumidas sem uma avaliação toxicológica sistemática, porque pelo histórico de uso, são geralmente considerados seguros para o consumo (COCKBURN, 2002).

Como já citado anteriormente, os órgãos que zelam pela saúde da população, lançam mão da avaliação das diferenças entre as culturas GMs e as tradicionais culturas convencionais com o uso do conceito de equivalência substancial (COCKBURN, 2002). Porém, muitos autores consideram tal abordagem pseudo-científica e não conclusiva, indicando ensaios mais profundos, como o uso das "omicas" como necessários para assegurar a inocuidade destes novos alimentos (KOK; KUIPER, 2003; KUIPER et al., 2002).

Ao mesmo tempo em que se discute que através do plantio das culturas GMs o uso de agrotóxicos é reduzido, levanta-se questões quanto aos possíveis danos na cadeia alimentar devido à eliminação das plantas daninhas ou ainda a tolerância em longo prazo destas aos herbicidas (CELEC et al., 2005).

Espera-se que nas culturas orgânicas, menores resíduos de agrotóxicos e nitratos que nas culturas convencionais sejam encontrados. Por outro lado, contaminantes ambientais estão igualmente presentes em alimentos de ambas as origens. Portanto, há uma necessidade de informações relacionadas com a segurança alimentar para informar ao consumidor dos benefícios para a saúde e riscos dos produtos alimentares de ambas as origens, a fim de otimizar o impacto na saúde e minimizar os riscos (MAGKOS; ARVANITI; ZAMPELAS, 2003). 
Magkos e colaboradores (2003) apóiam que quando as culturas convencionais são delineadas, com o manejo correto dos pesticidas e agrotóxicos, os perigos referentes ao uso destes são minimizados.

Vale destacar, que as amostras orgânicas foram cultivadas na mesma região das demais amostras, porém, em safras diferentes. Portanto, as alterações encontradas também podem ser discutidas pelo ponto de vista das variações de clima que estes cultivos sofreram. Como detectado por Zolla e cols (2007), entre suas amostras, as alterações por diferenças ambientais foram maiores que as diferenças advindas das modificações genéticas.

Portanto, os três meios de cultivo apresentam vantagens e desvantagens, principalmente quando estão em pauta questões econômicas e a inocuidade para a saúde dos consumidores. São necessários estudos mais profundos, do ponto de vista das “omicas" para uma avaliação mais completa e conclusiva sobre tais meios de cultivo, principalmente com as culturas orgânicas, pois, encontram-se poucos estudos nestas dimensões.

\subsection{Identificação das proteínas por espectrometria de massas}

Para um mapeamento e identificação dos principais grupos protéicos da soja, selecionamos 34 spots comuns em todas as amostras para realizar o sequenciamento dos peptídeos por espectrometria de massas. Identificamos os distintos spots de 1 a 34 (Figura 8). Para aumentar a concentração protéica agrupamos os spots de mesmo número das triplicatas dos géis.

Os spots 3 e 11 foram escolhidos no momento da avaliação dos spots que seriam excisados dos géis, porém, no momento do picote, percebeu-se que estes estavam em concentrações muito baixas e na maioria dos géis não foi possível localizá-los. Por este motivo, desistimos de identificá-los.

O equipamento utilizado foi o ESI-QUAD-TOF e com os espectros gerados, realizamos as buscas e identificações pelo programa MASCOT. Além das identificações protéicas, são obtidos dados de ponto isoelétrico, massa molecular e o número de acesso no NCBI. Estes e outros dados estão listados no Quadro 1.

Na primeira coluna do Quadro corresponde ao spot que esta sendo identificado (denominado de 1 a 34 conforme citado anteriormente) e a segunda coluna corresponde à 
amostra que esta sendo avaliada $(1,2,3,4,5$ e 6$)$. Vale ressaltar que o mapeamento dos 34 spots por amostra foi realizado entre as amostras GMs e suas estirpes genitoras.

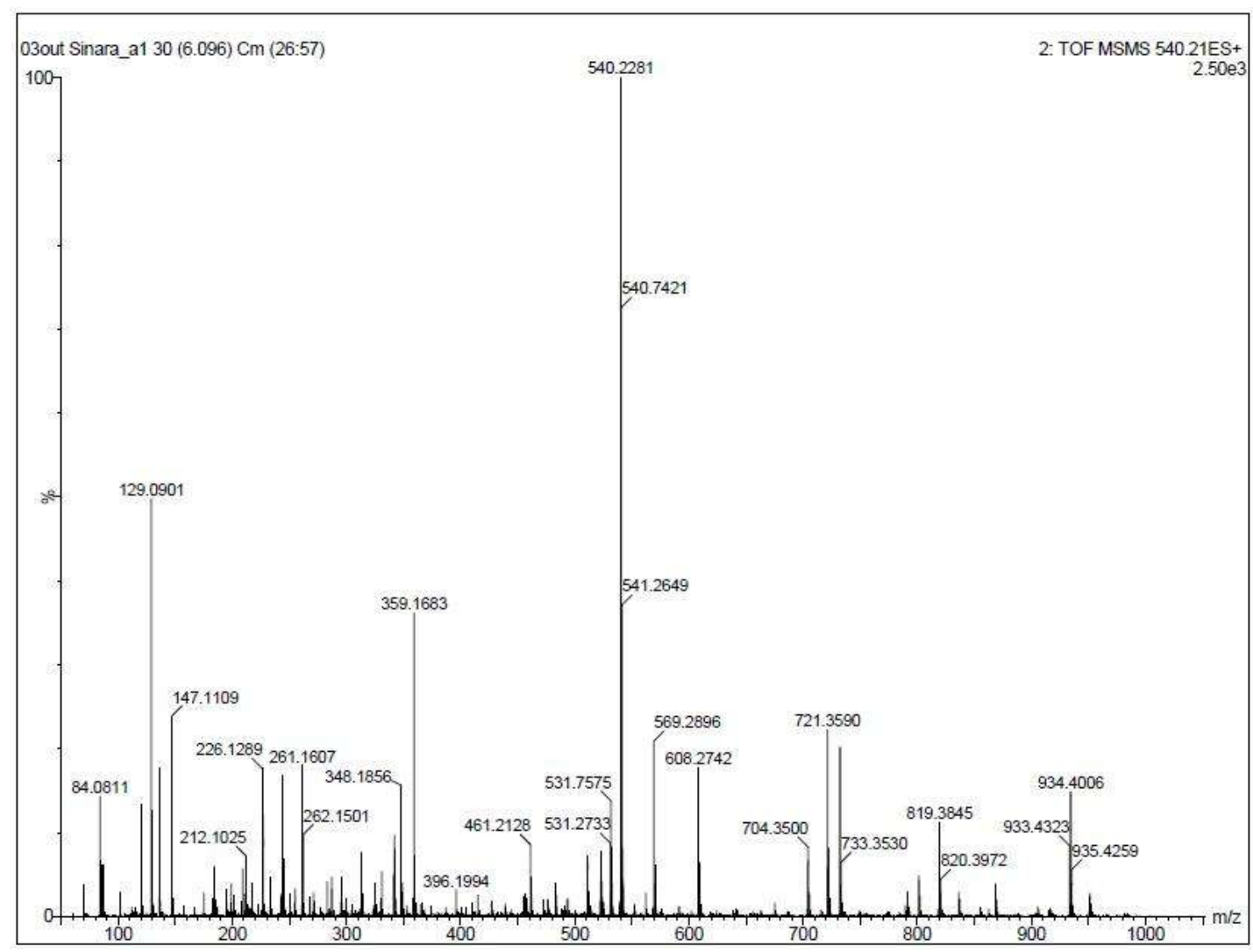

Figura 30: Espectro TOF MS/MS do spot 1 da amostra 1 , que foi identificada como Subunidade $\alpha$ da $\beta$ conglicinina, com cobertura de sequencia de $34 \%$. 
Quadro 1: Proteínas identificadas por espectrometria de massas:

\begin{tabular}{|c|c|c|c|c|c|c|c|c|c|}
\hline Spot & Amostra & Proteína identificada & $\begin{array}{l}\text { Número de } \\
\text { acesso no } \\
\text { NCBI }\end{array}$ & $\begin{array}{c}\text { Ponto } \\
\text { isoelétrico }\end{array}$ & $\begin{array}{c}\text { Massa } \\
\text { nominal }\end{array}$ & $\begin{array}{l}\text { Cobertura } \\
\text { de } \\
\text { sequência }\end{array}$ & Macths & $\begin{array}{l}\text { Seqüências } \\
\text { reconhecidas }\end{array}$ & Score \\
\hline \multirow{6}{*}{1} & 1 & Subunidade $\alpha$ da $\beta$-conglicinina & gi|9967357 & 4.92 & 63184 & 34 & 59 & 20 & 1492 \\
\hline & 2 & Subunidade $\alpha$ da $\beta$-conglicinina & gi 9967357 & 4.92 & 63184 & 33 & 41 & 14 & 1098 \\
\hline & 3 & Subunidade $\alpha$ da $\beta$-conglicinina & gi 9967357 & 4.92 & 63184 & 32 & 54 & 19 & 1326 \\
\hline & 4 & Subunidade $\alpha$ da $\beta$-conglicinina & gi 9967357 & 4.92 & 63184 & 31 & 62 & 19 & 1293 \\
\hline & 5 & Subunidade $\alpha$ da $\beta$-conglicinina & gi 9967357 & 4.92 & 63184 & 35 & 53 & 20 & 928 \\
\hline & 6 & Subunidade $\alpha$ da $\beta$-conglicinina & gi 9967357 & 4.92 & 63184 & 34 & 35 & 19 & 618 \\
\hline \multirow{6}{*}{2} & 1 & Subunidade $\alpha$ ' da $\beta$-conglicinina & gi| 9967361 & 5.23 & 65160 & 19 & 29 & 13 & 669 \\
\hline & 2 & Subunidade $\alpha^{\prime}$ da $\beta$-conglicinina & gi|9967361 & 5.23 & 65160 & 31 & 39 & 21 & 585 \\
\hline & 3 & Subunidade $\alpha^{\prime}$ da $\beta$-conglicinina & gi|9967361 & 5.23 & 65160 & 34 & 58 & 23 & 1162 \\
\hline & 4 & Subunidade $\alpha^{\prime}$ da $\beta$-conglicinina & gi| 9967361 & 5.23 & 65160 & 29 & 36 & 20 & 473 \\
\hline & 5 & Subunidade $\alpha$ ' da $\beta$-conglicinina & gi 9967361 & 5.23 & 65160 & 32 & 30 & 19 & 566 \\
\hline & 6 & Subunidade $\alpha$ ' da $\beta$-conglicinina & gi|9967361 & 5.23 & 65160 & 33 & 35 & 21 & 631 \\
\hline 3 & & & & & & & & & \\
\hline \multirow{12}{*}{4} & \multirow[t]{2}{*}{1} & $\begin{array}{l}\text { Estrutura recombinante cristalina e nativa de } \\
\text { soja } \beta \text {-conglicinina complexada com } \mathrm{N} \text {-acetil- } \\
\text { D-glucosamina }\end{array}$ & gi|21465628 & 5.67 & 47879 & 41 & 32 & 17 & 794 \\
\hline & & Subunidade $\beta$ da $\beta$-conglicinina & gi|9967359 & 5,67 & 47947 & 41 & 30 & 16 & 732 \\
\hline & \multirow[t]{3}{*}{2} & $\begin{array}{l}\text { Estrutura recombinante cristalina e nativa de } \\
\text { soja } \beta \text {-conglicinina complexada com } \mathrm{N} \text {-acetil- } \\
\text { D-glucosamina }\end{array}$ & gi|21465628 & 5.67 & 47947 & 41 & 27 & 19 & 586 \\
\hline & & Subunidade $\beta$ da $\beta$-conglicinina & gi 63852207 & 5,67 & 48358 & 41 & 27 & 19 & 536 \\
\hline & & Subunidade $\beta$ da $\beta$-conglicinina & gi|9967359 & 5,67 & 47947 & 41 & 27 & 19 & 526 \\
\hline & \multirow[t]{3}{*}{3} & $\begin{array}{l}\text { Estrutura recombinante cristalina e nativa de } \\
\text { soja } \beta \text {-conglicinina complexada com N-acetil- } \\
\text { D-glucosamina }\end{array}$ & gi| 21465628 & 5.67 & 47947 & 41 & 24 & 18 & 228 \\
\hline & & Subunidade $\beta$ da $\beta$-conglicinina & gi 63852207 & 5,67 & 48358 & 41 & 22 & 17 & 213 \\
\hline & & Subunidade $\beta$ da $\beta$-conglicinina & gi|9967359 & 5,67 & 47947 & 41 & 23 & 17 & 213 \\
\hline & 4 & DADO PERDIDO & & & & & & & \\
\hline & \multirow{3}{*}{5} & Subunidade $\beta$ da $\beta$-conglicinina & gi|9967359 & 5,67 & 47947 & 43 & 28 & 15 & 459 \\
\hline & & $\begin{array}{l}\text { Estrutura recombinante cristalina e nativa de } \\
\text { soja } \beta \text {-conglicinina complexada com N-acetil- } \\
\text { D-glucosamina }\end{array}$ & gi|21465628 & 5.67 & 47947 & 43 & 27 & 16 & 457 \\
\hline & & Subunidade $\beta$ da $\beta$-conglicinina & gi|63852207 & 5,67 & 48358 & 43 & 27 & 16 & 428 \\
\hline
\end{tabular}




\begin{tabular}{|c|c|c|c|c|c|c|c|c|c|}
\hline & \multirow{2}{*}{6} & Subunidade $\beta$ da $\beta$-conglicinina & gi|63852207 & 5,67 & 48358 & 43 & 30 & 19 & 427 \\
\hline & & Precursor da $\beta$-conglicinina & gi|121282 & 5.88 & 50578 & 41 & 28 & 18 & 388 \\
\hline \multirow{15}{*}{5} & \multirow[t]{2}{*}{1} & $\begin{array}{l}\text { Estrutura recombinante cristalina e nativa de } \\
\text { soja } \beta \text {-conglicinina complexada com N-acetil- } \\
\text { D-glucosamina }\end{array}$ & gi|21465628 & 5.67 & 47947 & 43 & 35 & 18 & 1083 \\
\hline & & Subunidade $\beta$ da $\beta$-conglicinina & gi|63852207 & 5,67 & 48358 & 43 & 35 & 18 & 1044 \\
\hline & \multirow{3}{*}{2} & Subunidade $\beta$ da $\beta$-conglicinina & gi|9967359 & 5,67 & 47947 & & 25 & 16 & 487 \\
\hline & & $\begin{array}{l}\text { Estrutura recombinante cristalina e nativa de } \\
\text { soja } \beta \text {-conglicinina complexada com N-acetil- } \\
\text { D-glucosamina }\end{array}$ & gi|21465628 & 5.67 & 47947 & 36 & 24 & 15 & 481 \\
\hline & & Subunidade $\beta$ da $\beta$-conglicinina & gi|63852207 & 5.67 & 48358 & 36 & 25 & 16 & 477 \\
\hline & \multirow[t]{3}{*}{3} & $\begin{array}{l}\text { Estrutura recombinante cristalina e nativa de } \\
\text { soja } \beta \text {-conglicinina complexada com N-acetil- } \\
\text { D-glucosamina }\end{array}$ & gi|21465628 & 5.67 & 47947 & 47 & 29 & 20 & 572 \\
\hline & & Subunidade $\beta$ da $\beta$-conglicinina & gi|63852207 & 5,67 & 48358 & 47 & 32 & 21 & 559 \\
\hline & & Subunidade $\beta$ da $\beta$-conglicinina & gi|9967359 & 5,67 & 47947 & 47 & 30 & 20 & 553 \\
\hline & \multirow[t]{2}{*}{4} & $\begin{array}{l}\text { Estrutura recombinante cristalina e nativa de } \\
\text { soja } \beta \text {-conglicinina complexada com N-acetil- } \\
\text { D-glucosamina }\end{array}$ & gi|21465628 & 5.67 & 47947 & 36 & 31 & 16 & 497 \\
\hline & & Subunidade $\beta$ da $\beta$-conglicinina & gi| 9967359 & 5.67 & 47947 & 34 & 30 & 15 & 457 \\
\hline & \multirow[t]{3}{*}{5} & $\begin{array}{l}\text { Estrutura recombinante cristalina e nativa de } \\
\text { soja } \beta \text {-conglicinina complexada com N-acetil- } \\
\text { D-glucosamina }\end{array}$ & gi|21465628 & 5.67 & 47947 & 34 & 24 & 16 & 446 \\
\hline & & Subunidade $\beta$ da $\beta$-conglicinina & gi|9967359 & 5.67 & 47947 & 34 & 26 & 16 & 402 \\
\hline & & Subunidade $\beta$ da $\beta$-conglicinina & gi|63852207 & 5,67 & 48358 & 34 & 24 & 16 & 391 \\
\hline & 6 & Subunidade $\beta$ da $\beta$-conglicinina & gi| 9967359 & 5,67 & 47947 & 44 & 27 & 18 & 370 \\
\hline & 0 & Subunidade $\beta$ da $\beta$-conglicinina & gi|63852207 & 5,67 & 48358 & 43 & 27 & 18 & 369 \\
\hline \multirow{7}{*}{6} & \multirow{2}{*}{1} & Subunidade $\beta$ da $\beta$-conglicinina & gi|63852207 & 5,67 & 48358 & 33 & 25 & 13 & 682 \\
\hline & & Precursor da $\beta$-conglicinina & gi|121282 & 5.88 & 50578 & 31 & 25 & 12 & 668 \\
\hline & 2 & Subunidade $\beta$ da $\beta$-conglicinina & gi|63852207 & 5.67 & 48358 & 35 & 20 & 15 & 358 \\
\hline & \multirow[t]{3}{*}{3} & $\begin{array}{l}\text { Estrutura recombinante cristalina e nativa de } \\
\text { soja } \beta \text {-conglicinina complexada com N-acetil- } \\
\text { D-glucosamina }\end{array}$ & gi|21465628 & 5.67 & 47947 & 39 & 28 & 19 & 581 \\
\hline & & Subunidade $\beta$ da $\beta$-conglicinina & gi|9967359 & 5.67 & 47947 & 38 & 29 & 18 & 554 \\
\hline & & Subunidade $\beta$ da $\beta$-conglicinina & gi|63852207 & 5.67 & 48358 & 38 & 28 & 19 & 524 \\
\hline & 4 & $\begin{array}{l}\text { Estrutura recombinante cristalina e nativa de } \\
\text { soja } \beta \text {-conglicinina complexada com N-acetil- } \\
\text { D-glucosamina }\end{array}$ & gi|21465628 & 5.67 & 47947 & 30 & 25 & 13 & 587 \\
\hline
\end{tabular}




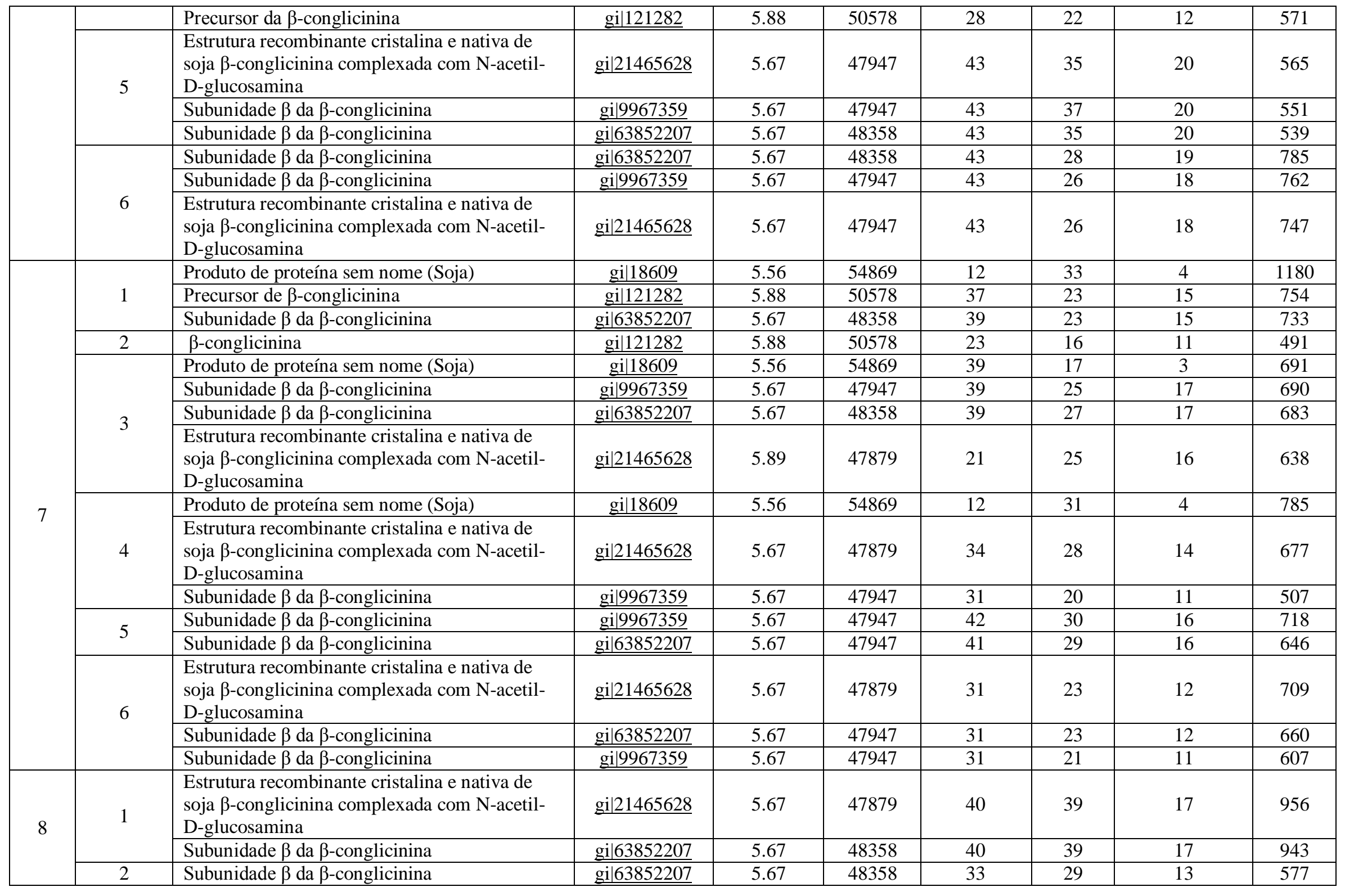




\begin{tabular}{|c|c|c|c|c|c|c|c|c|c|}
\hline & \multirow[t]{3}{*}{3} & $\begin{array}{l}\text { Estrutura recombinante cristalina e nativa de } \\
\text { soja } \beta \text {-conglicinina complexada com } \mathrm{N} \text {-acetil- } \\
\text { D-glucosamina }\end{array}$ & gi|21465628 & 5.67 & 47879 & 37 & 28 & 18 & 438 \\
\hline & & $\beta$-conglicinina & gi|121282 & 5.88 & 50578 & 32 & 24 & 15 & 360 \\
\hline & & Produto de proteína sem nome (Soja) & gi|18609 & 5.56 & 54869 & 13 & 21 & 4 & 342 \\
\hline & \multirow[t]{3}{*}{4} & $\begin{array}{l}\text { Estrutura recombinante cristalina e nativa de } \\
\text { soja } \beta \text {-conglicinina complexada com } \mathrm{N} \text {-acetil- } \\
\text { D-glucosamina }\end{array}$ & gi|21465628 & 5.67 & 47879 & 35 & 35 & 17 & 772 \\
\hline & & Subunidade $\beta$ da $\beta$-conglicinina & gi|63852207 & 5.67 & 48358 & 34 & 36 & 17 & 708 \\
\hline & & Subunidade $\beta$ da $\beta$-conglicinina & gi|9967359 & 5.67 & 47947 & 34 & 35 & 16 & 689 \\
\hline & \multirow[b]{3}{*}{5} & Subunidade $\beta$ da $\beta$-conglicinina & gi|63852207 & 5.67 & 48358 & 45 & 35 & 19 & 676 \\
\hline & & Subunidade $\beta$ da $\beta$-conglicinina & gi|9967359 & 5.67 & 47947 & 45 & 32 & 18 & 669 \\
\hline & & $\begin{array}{l}\text { Estrutura recombinante cristalina e nativa de } \\
\text { soja } \beta \text {-conglicinina complexada com } N \text {-acetil- } \\
\text { D-glucosamina }\end{array}$ & gi|21465628 & 5.67 & 47879 & 46 & 35 & 19 & 660 \\
\hline & \multirow{3}{*}{6} & $\beta$-conglicinina & gi|121282 & 5.88 & 50578 & 38 & 38 & 16 & 678 \\
\hline & & $\begin{array}{l}\text { Estrutura recombinante cristalina e nativa de } \\
\text { soja } \beta \text {-conglicinina complexada com } \mathrm{N} \text {-acetil- } \\
\text { D-glucosamina }\end{array}$ & gi|21465628 & 5.67 & 47879 & 38 & 37 & 17 & 672 \\
\hline & & Subunidade $\beta$ da $\beta$-conglicinina & gi 63852207 & 5.67 & 48358 & 38 & 39 & 17 & 670 \\
\hline \multirow{10}{*}{9} & \multirow{2}{*}{1} & Glicinina & gi|18641 & 5.21 & 64351 & 18 & 68 & 8 & 2491 \\
\hline & & Subunidade G4 Glicinina & gi|121279 & 5.29 & 64005 & 18 & 67 & 8 & 2452 \\
\hline & 2 & Glicinina & gi|18641 & 5.21 & 64351 & 19 & 31 & 8 & 1200 \\
\hline & \multirow{2}{*}{3} & Glicinina & gi 18641 & 5.21 & 64351 & 20 & 43 & 8 & 2035 \\
\hline & & Produto de proteína sem nome (Soja) & gi|18609 & 5.56 & 54869 & 21 & 10 & 5 & 490 \\
\hline & \multirow{2}{*}{4} & Glicinina & gi 18641 & 5.21 & 64351 & 24 & 46 & 11 & 1434 \\
\hline & & Subunidade G2 Glicinina & gi 18637 & 5.46 & 54927 & 25 & 21 & 8 & 289 \\
\hline & \multirow{2}{*}{5} & Glicinina & gi|18641 & 5.21 & 64351 & 20 & 25 & 10 & 455 \\
\hline & & Subunidade A3 Glicinina & gi|121280 & 5.60 & 58377 & 18 & 7 & 3 & 118 \\
\hline & 6 & Glicinina & gi|18641 & 5.21 & 64351 & 24 & 25 & 11 & 476 \\
\hline \multirow{8}{*}{10} & \multirow{2}{*}{1} & Glicinina & gi|18641 & 5.21 & 64351 & 22 & 20 & 8 & 545 \\
\hline & & Provável protease Tiol P34 & gi|129353 & 5.74 & 43109 & 11 & 14 & 5 & 495 \\
\hline & \multirow{2}{*}{2} & Precursor protease Tiol $34 \mathrm{kDa}$ & gi 1199563 & 5.65 & 43091 & 16 & 10 & 5 & 557 \\
\hline & & Glicinina & gi|18641 & $5 . .21$ & 64351 & 4 & 1 & 1 & 149 \\
\hline & \multirow{2}{*}{3} & Glicinina & gi|18641 & 5.21 & 64351 & 20 & 23 & 9 & 855 \\
\hline & & Precursor protease Tiol $34 \mathrm{kDa}$ & gi|1199563 & 5.65 & 43091 & 16 & 17 & 6 & 578 \\
\hline & \multirow{2}{*}{4} & Glicinina & gi|18641 & 5.21 & 64351 & 20 & 22 & 6 & 883 \\
\hline & & Provável protease Tiol P34 & gi||129353 & 5.74 & 43109 & 11 & 18 & 6 & 372 \\
\hline
\end{tabular}




\begin{tabular}{|c|c|c|c|c|c|c|c|c|c|}
\hline & & $\begin{array}{l}\text { Estrutura recombinante cristalina subunidade } \\
\text { Pro-glicinina A3b4 }\end{array}$ & gi|119389108 & 5.46 & 55914 & 6 & 4 & 2 & 180 \\
\hline & \multirow{2}{*}{5} & Glicinina & gi|18641 & 5.21 & 64351 & 19 & 8 & 6 & 321 \\
\hline & & Precursor protease Tiol $34 \mathrm{kDa}$ & gi|1199563 & 5.65 & 43091 & 16 & 15 & 6 & 247 \\
\hline & \multirow{2}{*}{6} & Provável protease Tiol P34 & gi| 129353 & 5.74 & 43109 & 11 & 14 & 5 & 289 \\
\hline & & Glicinina & gi|18641 & 5.21 & 64351 & 19 & 14 & 7 & 275 \\
\hline 11 & & & & & & & & & \\
\hline \multirow{7}{*}{12} & 1 & Dehidrina & gi|37495451 & 5.97 & 23774 & 61 & 32 & 11 & 625 \\
\hline & 2 & Dehidrina & gi|37495451 & 5.97 & 23774 & 50 & 24 & 11 & 648 \\
\hline & 3 & Proteína associada à maturação & gi| 170024 & 6.07 & 23700 & 50 & 23 & 9 & 366 \\
\hline & \multirow{2}{*}{4} & Dehidrina & gi|37495451 & 5.97 & 23774 & 65 & 16 & 8 & 294 \\
\hline & & Proteína associada à maturação & gi|170024 & & 23700 & & 15 & 8 & 287 \\
\hline & 5 & Como a proteína Dehidrina & gi|497417 & 6.07 & 23704 & 73 & 17 & 10 & 498 \\
\hline & 6 & Como a proteína Dehidrina & gi|497417 & 6.07 & 23704 & 57 & 18 & 10 & 347 \\
\hline \multirow{7}{*}{13} & \multirow{2}{*}{1} & Produto de proteína sem nome (Soja) & gi|18543 & 8.61 & 47117 & 12 & 5 & 3 & 267 \\
\hline & & Produto de proteína sem nome (Soja) & gi|218336143 & 6.57 & 41925 & 21 & 18 & 8 & 133 \\
\hline & 2 & Produto de proteína sem nome (Soja) & gi|218336143 & 6.57 & 41925 & 18 & 18 & 7 & 164 \\
\hline & 3 & Produto de proteína sem nome (Soja) & gi|18543 & 8.61 & 47117 & 11 & 4 & 3 & 72 \\
\hline & 4 & CONTAMINADA & & & & & & & \\
\hline & 5 & Globulina 7S básica & gi|434061 & 8.68 & 47105 & 10 & 6 & 4 & 102 \\
\hline & 6 & Produto de proteína sem nome (Soja) & gi|18543 & 8.61 & 47117 & 14 & 8 & 4 & 88 \\
\hline \multirow{12}{*}{14} & \multirow{2}{*}{1} & Produto de proteína sem nome (Soja) & gi|218336143 & 6.14 & 41925 & 11 & 30 & 16 & 652 \\
\hline & & Álcool desidrogenase (fragmento 1) & gi|22597178 & 6.19 & 40722 & 26 & 15 & 9 & 245 \\
\hline & \multirow{2}{*}{2} & Produto de proteína sem nome (Soja) & gi|218336143 & 6.14 & 41925 & 53 & 34 & 18 & 620 \\
\hline & & Álcool desidrogenase (fragmento 1) & gi|22597178 & 6.19 & 40722 & 21 & 14 & 8 & 216 \\
\hline & \multirow{2}{*}{3} & Produto de proteína sem nome (Soja) & gi|218336143 & 6.14 & 41925 & 44 & 31 & 16 & 602 \\
\hline & & Álcool desidrogenase (fragmento 1) & gi|22597178 & 6.19 & 40722 & 27 & 18 & 10 & 358 \\
\hline & \multirow{2}{*}{4} & Produto de proteína sem nome (Soja) & gi|218336143 & 6.14 & 41925 & 39 & 25 & 14 & 572 \\
\hline & & Álcool desidrogenase (fragmento 1) & gi|22597178 & 6.19 & 40722 & 29 & 15 & 11 & 218 \\
\hline & \multirow{2}{*}{5} & Produto de proteína sem nome (Soja) & gi|218336143 & 6.14 & 41925 & 45 & 32 & 16 & 499 \\
\hline & & Álcool desidrogenase (fragmento 1) & gi|22597178 & 6.19 & 40722 & 29 & 20 & 11 & 312 \\
\hline & 6 & Produto de proteína sem nome (Soja) & gi|218336143 & 6.14 & 41925 & 41 & 34 & 16 & 604 \\
\hline & & Álcool desidrogenase (fragmento 1) & gi|22597178 & 6.19 & 40722 & 26 & 19 & 12 & 261 \\
\hline \multirow{2}{*}{15} & 1 & $\begin{array}{l}\text { Aglutinina de soja complexada com 2,6 } \\
\text { pentasacarídeo }\end{array}$ & gi|6729836 & 5.15 & 27555 & 25 & 18 & 5 & 820 \\
\hline & 2 & $\begin{array}{l}\text { Aglutinina de soja complexada com 2,6 } \\
\text { pentasacarídeo }\end{array}$ & gi|6729836 & 5.15 & 27555 & 25 & 13 & 5 & 725 \\
\hline
\end{tabular}




\begin{tabular}{|c|c|c|c|c|c|c|c|c|c|}
\hline & 3 & $\begin{array}{l}\text { Aglutinina de soja complexada com 2,6 } \\
\text { pentasacarídeo }\end{array}$ & gi|6729836 & 5.15 & 27555 & 24 & 17 & 5 & 827 \\
\hline & 4 & $\begin{array}{l}\text { Aglutinina de soja complexada com 2,6 } \\
\text { pentasacarídeo }\end{array}$ & gi|6729836 & 5.15 & 27555 & 39 & 30 & 8 & 740 \\
\hline & 5 & $\begin{array}{l}\text { Aglutinina de soja complexada com 2,6 } \\
\text { pentasacarídeo }\end{array}$ & gi|6729836 & 5.15 & 27555 & 34 & 33 & 7 & 494 \\
\hline & 6 & $\begin{array}{l}\text { Aglutinina de soja complexada com 2,6 } \\
\text { pentasacarídeo }\end{array}$ & gi|6729836 & 5.15 & 27555 & 34 & 22 & 7 & 757 \\
\hline \multirow{13}{*}{16} & 1 & Subunidade G1 Glicinina & gi|18635 & 5.89 & 56299 & 10 & 10 & 6 & 340 \\
\hline & 2 & Subunidade G1 Glicinina & gi 18635 & 5.89 & 56299 & 6 & 8 & 4 & 240 \\
\hline & 3 & Subunidade G1 Glicinina & $\begin{array}{ll}\text { gi } 18635 \\
\end{array}$ & 5.89 & 56299 & 9 & 7 & 5 & 236 \\
\hline & \multirow{3}{*}{4} & Subunidade G1 Glicinina & gi|18635 & 5.89 & 56299 & 12 & 14 & 7 & 512 \\
\hline & & Produto de proteína sem nome (Soja) & gi 18609 & 5.56 & 54869 & 12 & 10 & 4 & 509 \\
\hline & & Subunidade G3 Glicinina & gi 18639 & 5.73 & 54835 & 8 & 8 & 3 & 354 \\
\hline & \multirow{4}{*}{5} & Subunidade G1 Glicinina & gi 18635 & 5.89 & 56299 & 16 & 22 & 8 & 651 \\
\hline & & Subunidade G3 Glicinina & gi|18639 & 5.73 & 54835 & 10 & 11 & 3 & 580 \\
\hline & & Precursor da subunidade G3 Glicinina & gi|99909 & 5.28 & 54953 & 8 & 10 & 3 & 461 \\
\hline & & Produto de proteína sem nome (Soja) & gi|18609 & 5.56 & 54869 & 7 & 10 & 3 & 408 \\
\hline & \multirow{3}{*}{6} & Subunidade G1 Glicinina & gi 18635 & 5.89 & 56299 & 16 & 27 & 9 & 581 \\
\hline & & Subunidade G3 Glicinina & gi| 18639 & 5.73 & 54835 & 10 & 14 & 3 & 330 \\
\hline & & Precursor da subunidade G3 Glicinina & gi|99909 & 5.56 & 54953 & 12 & 15 & 4 & 251 \\
\hline \multirow{16}{*}{17} & \multirow{2}{*}{1} & Subunidade G1 Glicinina & gi 18635 & 5.89 & 56299 & 14 & 28 & 8 & 415 \\
\hline & & Subunidade G2 Glicinina & gi 18637 & 5.46 & 54927 & 11 & 9 & 4 & 324 \\
\hline & 2 & Produto de proteína sem nome (Soja) & gi|18609 & 5.56 & 54869 & 12 & 6 & 4 & 275 \\
\hline & \multirow{2}{*}{3} & Produto de proteína sem nome (Soja) & gi 18609 & 5.56 & 54869 & 4 & 7 & 3 & 260 \\
\hline & & Produto de proteína sem nome (Soja) & gi 18615 & 6.15 & 56099 & 5 & 7 & 3 & 256 \\
\hline & \multirow{3}{*}{4} & Subunidade G1 Glicinina & gi|18635 & 5.89 & 56299 & 16 & 27 & 9 & 616 \\
\hline & & Produto de proteína sem nome (Soja) & gi|18609 & 5.56 & 54869 & 12 & 14 & 4 & 524 \\
\hline & & Subunidade G3 Glicinina & \begin{tabular}{l|l|} 
gi 18639 \\
\end{tabular} & 5.73 & 54835 & 10 & 11 & 3 & 505 \\
\hline & \multirow{4}{*}{5} & Subunidade G1 Glicinina & gi| 18635 & 5.89 & 56299 & 16 & 26 & 8 & 523 \\
\hline & & Subunidade G3 Glicinina & gi|18639 & 5.73 & 54835 & 10 & 9 & 3 & 376 \\
\hline & & Produto de proteína sem nome (Soja) & gi| 18609 & 5.56 & 54869 & 7 & 8 & 3 & 272 \\
\hline & & Subunidade G4 Glicinina & gi|255224 & 5.38 & 64097 & 5 & 4 & 2 & 172 \\
\hline & \multirow{4}{*}{6} & Subunidade G1 Glicinina & gi|18635 & 5.89 & 56299 & 16 & 28 & 8 & 733 \\
\hline & & Subunidade G3 Glicinina & gi| 18639 & 5.73 & 54835 & 10 & 13 & 3 & 506 \\
\hline & & Produto de proteína sem nome (Soja) & \begin{tabular}{l|l|l|l|} 
gi & 18609 \\
\end{tabular} & 5.56 & 54869 & 7 & 12 & 3 & 433 \\
\hline & & Precursor da subunidade G3 Glicinina & gi|99909 & 5.28 & 54953 & 8 & 12 & 3 & 376 \\
\hline
\end{tabular}




\begin{tabular}{|c|c|c|c|c|c|c|c|c|c|}
\hline \multirow{20}{*}{18} & \multirow{2}{*}{1} & Glicinina & gi|18641 & 5.21 & 64351 & 17 & 19 & 9 & 423 \\
\hline & & Subunidade G4 Glicinina & gi|255224 & 5.38 & 64097 & 15 & 15 & 7 & 278 \\
\hline & \multirow{3}{*}{2} & Precursor da subunidade G3 Glicinina & gi|99909 & 5.28 & 54953 & 8 & 6 & 3 & 302 \\
\hline & & Glicinina & gi| 18641 & 5.21 & 64351 & 12 & 13 & 6 & 279 \\
\hline & & Subunidade G1 Glicinina & gi 18635 & 5.89 & 56299 & 8 & 6 & 4 & 237 \\
\hline & \multirow{3}{*}{3} & Subunidade G1 Glicinina & \begin{tabular}{l|l|} 
gi 18635 \\
\end{tabular} & 5.89 & 56299 & 17 & 12 & 8 & 252 \\
\hline & & Subunidade G3 Glicinina & gi 18639 & 5.73 & 54835 & 10 & 7 & 3 & 241 \\
\hline & & Precursor da subunidade G3 Glicinina & gi|99909 & 5.28 & 54953 & 10 & 5 & 3 & 190 \\
\hline & 4 & Glicinina & gi|18641 & 5.21 & 64351 & 8 & 7 & 4 & 148 \\
\hline & \multirow{5}{*}{5} & Produto de proteína sem nome (Soja) & gi 18609 & 5.56 & 54869 & 10 & 8 & 5 & 364 \\
\hline & & Subunidade G1 Glicinina & gi| 18635 & 5.89 & 56299 & 13 & 11 & 7 & 338 \\
\hline & & Subunidade G3 Glicinina & gi 18639 & 5.73 & 54835 & 8 & 5 & 3 & 321 \\
\hline & & Precursor da subunidade G3 Glicinina & gi|99909 & 5.28 & 54953 & 6 & 5 & 3 & 289 \\
\hline & & Subunidade G4 Glicinina & gi| 255224 & 5.38 & 64097 & 12 & 9 & 6 & 162 \\
\hline & \multirow{6}{*}{6} & Produto de proteína sem nome (Soja) & gi|18609 & 5.56 & 54869 & 12 & 11 & 4 & 459 \\
\hline & & Subunidade G1 Glicinina & \begin{tabular}{l|l|l|} 
& 18635 \\
\end{tabular} & 5.89 & 56299 & 8 & 10 & 4 & 331 \\
\hline & & Subunidade G3 Glicinina & gi|18639 & 5.73 & 54835 & 5 & 6 & 2 & 232 \\
\hline & & Precursor da subunidade G3 Glicinina & gi|99909 & 5.28 & 54953 & 4 & 6 & 2 & 215 \\
\hline & & Subunidade G4 Glicinina & gi|255224 & 5.38 & 64097 & 4 & 7 & 6 & 138 \\
\hline & & Glicinina & gi|18641 & & 64351 & 4 & 7 & 6 & 120 \\
\hline \multirow{17}{*}{19} & \multirow{2}{*}{1} & Subunidade G4 Glicinina & gi| 121279 & 5.29 & 64005 & 17 & 34 & 10 & 665 \\
\hline & & Glicinina & gi 121280 & 5.60 & 58337 & 11 & 16 & 6 & 420 \\
\hline & 2 & Glicinina & gi|18641 & 5.21 & 64351 & 13 & 12 & 6 & 195 \\
\hline & \multirow{2}{*}{3} & Glicinina & gi 18641 & 5.21 & 64351 & 28 & 28 & 12 & 445 \\
\hline & & Subunidade G4 Glicinina & gi|255224 & 5.38 & 64097 & 26 & 28 & 12 & 384 \\
\hline & 4 & Glicinina & gi|18641 & 5.21 & 64351 & 20 & 16 & 9 & 370 \\
\hline & \multirow{6}{*}{5} & Produto de proteína sem nome (Soja) & gi|18609 & 5.56 & 54869 & 12 & 15 & 5 & 367 \\
\hline & & Subunidade G4 Glicinina & gi| 121279 & 5.29 & 64005 & 20 & 20 & 10 & 358 \\
\hline & & Subunidade G4 Glicinina & gi| 255224 & 5.38 & 64097 & 18 & 19 & 8 & 330 \\
\hline & & Precursor da subunidade G3 Glicinina & gi|99909 & 5.28 & 54953 & 8 & 8 & 5 & 226 \\
\hline & & Subunidade G3 Glicinina & \begin{tabular}{l|l|l|} 
gi & 18639 \\
\end{tabular} & 5.73 & 54835 & 5 & 7 & 2 & 199 \\
\hline & & Subunidade G1 Glicinina & gi 18635 & 5.89 & 56299 & 8 & 9 & 4 & 195 \\
\hline & \multirow{5}{*}{6} & Produto de proteína sem nome (Soja) & gi|18609 & 5.56 & 54869 & 14 & 16 & 6 & 311 \\
\hline & & Glicinina & gi|18641 & 5.21 & 64351 & 13 & 12 & 7 & 301 \\
\hline & & Subunidade G4 Glicinina & gi|255224 & 5.38 & 64097 & 15 & 12 & 7 & 279 \\
\hline & & Produto de proteína sem nome (Soja) & gi|18615 & 6.15 & 56099 & 12 & 13 & 3 & 213 \\
\hline & & Precursor da subunidade G3 Glicinina & gi|99909 & 5.29 & 54953 & 12 & 8 & 3 & 160 \\
\hline
\end{tabular}




\begin{tabular}{|c|c|c|c|c|c|c|c|c|c|}
\hline & & Subunidade G3 Glicinina & gi| 18639 & 5.73 & 54835 & 11 & 8 & 3 & 137 \\
\hline \multirow{10}{*}{20} & \multirow{2}{*}{1} & Inibidor de tripsina TIA & gi|354134 & 4.61 & 20310 & 48 & 25 & 10 & 550 \\
\hline & & Inibidor de tripsina Kunitz KTI1 & gi| 125722 & 4.97 & 22817 & 43 & 13 & 8 & 371 \\
\hline & 2 & Inibidor de tripsina TIA & gi|354134 & 4.61 & 20310 & 64 & 37 & 12 & 939 \\
\hline & \multirow{2}{*}{3} & Inibidor de tripsina TIA & gi|354134 & 4.61 & 20310 & 46 & 28 & 11 & 787 \\
\hline & & Inibidor de tripsina Kunitz KTI1 & gi 125722 & 4.97 & 22817 & 28 & 6 & 6 & 139 \\
\hline & \multirow{2}{*}{4} & Inibidor de tripsina TIA & gi|354134 & 4.61 & 20310 & 52 & 39 & 11 & 742 \\
\hline & & Inibidor de tripsina Kunitz KTI1 & gi|125722 & 4.97 & 22817 & 23 & 10 & 4 & 179 \\
\hline & \multirow{2}{*}{5} & Inibidor de tripsina TIA & gi 354134 & 4.61 & 20310 & 54 & 22 & 11 & 308 \\
\hline & & Inibidor de tripsina Kunitz KTI1 & gi| $\mid 125722$ & 4.97 & 22817 & 20 & 9 & 5 & 131 \\
\hline & 6 & Inibidor de tripsina TIA & gi|354134 & 4.61 & 20310 & 44 & 20 & 10 & 325 \\
\hline \multirow{16}{*}{21} & \multirow{3}{*}{1} & Inibidor de tripsina Kunitz KTI1 & gi| 125722 & 4.97 & 22817 & 45 & 25 & 10 & 622 \\
\hline & & Inibidor de tripsina Kunitz KTI2 & gi| 125723 & 6.14 & 23071 & 25 & 12 & 4 & 306 \\
\hline & & Inibidor de tripsina subtipo A & gi| 18770 & 4.99 & 24346 & 29 & 11 & 6 & 274 \\
\hline & \multirow{3}{*}{2} & Inibidor de tripsina Kunitz KTI1 & gi| 125722 & 4.97 & 22817 & 43 & 25 & 11 & 530 \\
\hline & & Inibidor de tripsina Kunitz KTI2 & gi| 125723 & 6.14 & 23071 & 25 & 10 & 4 & 221 \\
\hline & & Inibidor de tripsina subtipo A & gi|18770 & 4.99 & 24346 & 27 & 9 & 6 & 124 \\
\hline & \multirow{3}{*}{3} & Inibidor de tripsina Kunitz KTI1 & gi| 125722 & 4.97 & 22817 & 39 & 25 & 12 & 520 \\
\hline & & Precursor Inibidor de Tripsina Kunitz KTI2 & gi| 125723 & 6.14 & 23071 & 19 & 12 & 5 & 191 \\
\hline & & Inibidor de tripsina TIA & gi| 354134 & 4.61 & 20310 & 12 & 16 & 10 & 180 \\
\hline & \multirow{2}{*}{4} & Inibidor de tripsina Kunitz KTI1 & gi| 125722 & 4.97 & 22817 & 40 & 27 & 10 & 672 \\
\hline & & Inibidor de tripsina Kunitz KTI2 & gi 125723 & 6.14 & 23071 & 19 & 16 & 10 & 258 \\
\hline & \multirow{3}{*}{5} & Inibidor de tripsina Kunitz KTI1 & gi|125722 & 4.97 & 22817 & 39 & 24 & 9 & 524 \\
\hline & & Inibidor de tripsina Kunitz KTI2 & gi| 125723 & 6.14 & 23071 & 19 & 14 & 4 & 240 \\
\hline & & Inibidor de tripsina subtipo A & gi 18770 & 4.99 & 24346 & 37 & 13 & 9 & 144 \\
\hline & 6 & Inibidor de tripsina Kunitz KTI1 & gi||125722 & 4.97 & 22817 & 41 & 31 & 9 & 556 \\
\hline & 6 & Inibidor de tripsina Kunitz KTI2 & gi| 125723 & 6.14 & 23071 & 37 & 16 & 4 & 229 \\
\hline \multirow{6}{*}{22} & 1 & Produto de proteína sem nome (Soja) & gi|18536 & 5.07 & 70535 & 3 & 49 & 8 & 802 \\
\hline & 2 & CONTAMINADA & & & & & & & \\
\hline & 3 & Produto de proteína sem nome (Soja) & gi|18536 & 5.07 & 70535 & 6 & 22 & 3 & 325 \\
\hline & 4 & Produto de proteína sem nome (Soja) & \begin{tabular}{l|l|l|} 
gi 18536 \\
\end{tabular} & 5.07 & 70535 & 5 & 28 & 3 & 596 \\
\hline & 5 & Produto de proteína sem nome (Soja) & gi|18536 & 5.07 & 70535 & 4 & 10 & 2 & 180 \\
\hline & 6 & CONTAMINADA & & & & & & & \\
\hline \multirow{4}{*}{23} & 1 & Glicinina & gi|4249566 & 5.52 & 58650 & 17 & 25 & 9 & 1228 \\
\hline & 2 & Glicinina & gi| 4249566 & 5.52 & 58650 & 8 & 13 & 4 & 698 \\
\hline & \multirow{2}{*}{3} & Glicinina & gi|4249566 & 5.52 & 58650 & 31 & 32 & 10 & 1033 \\
\hline & & Subunidade A3 Glicinina & gi|121280 & 5.60 & 58377 & 31 & 29 & 9 & 786 \\
\hline
\end{tabular}




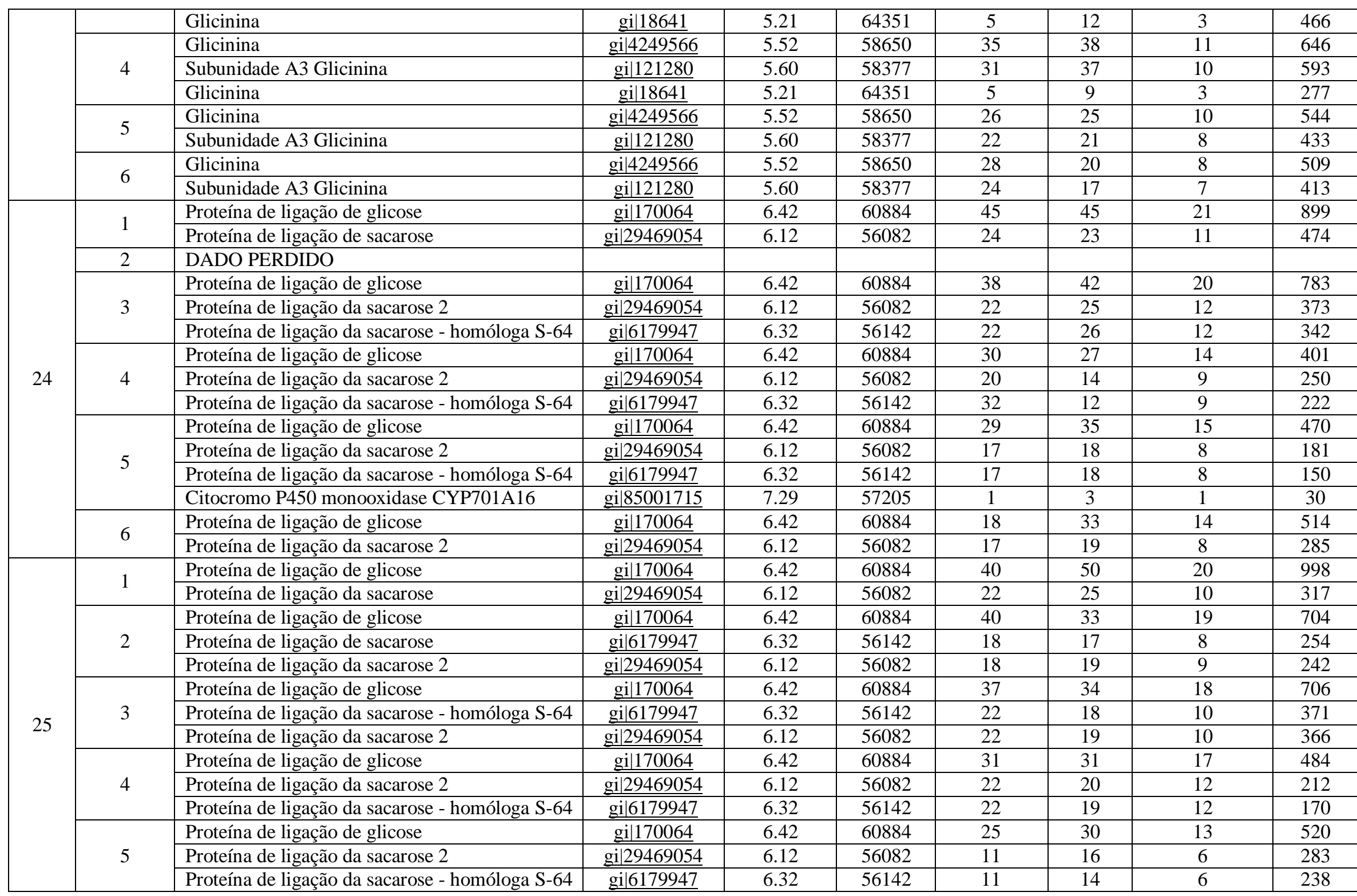




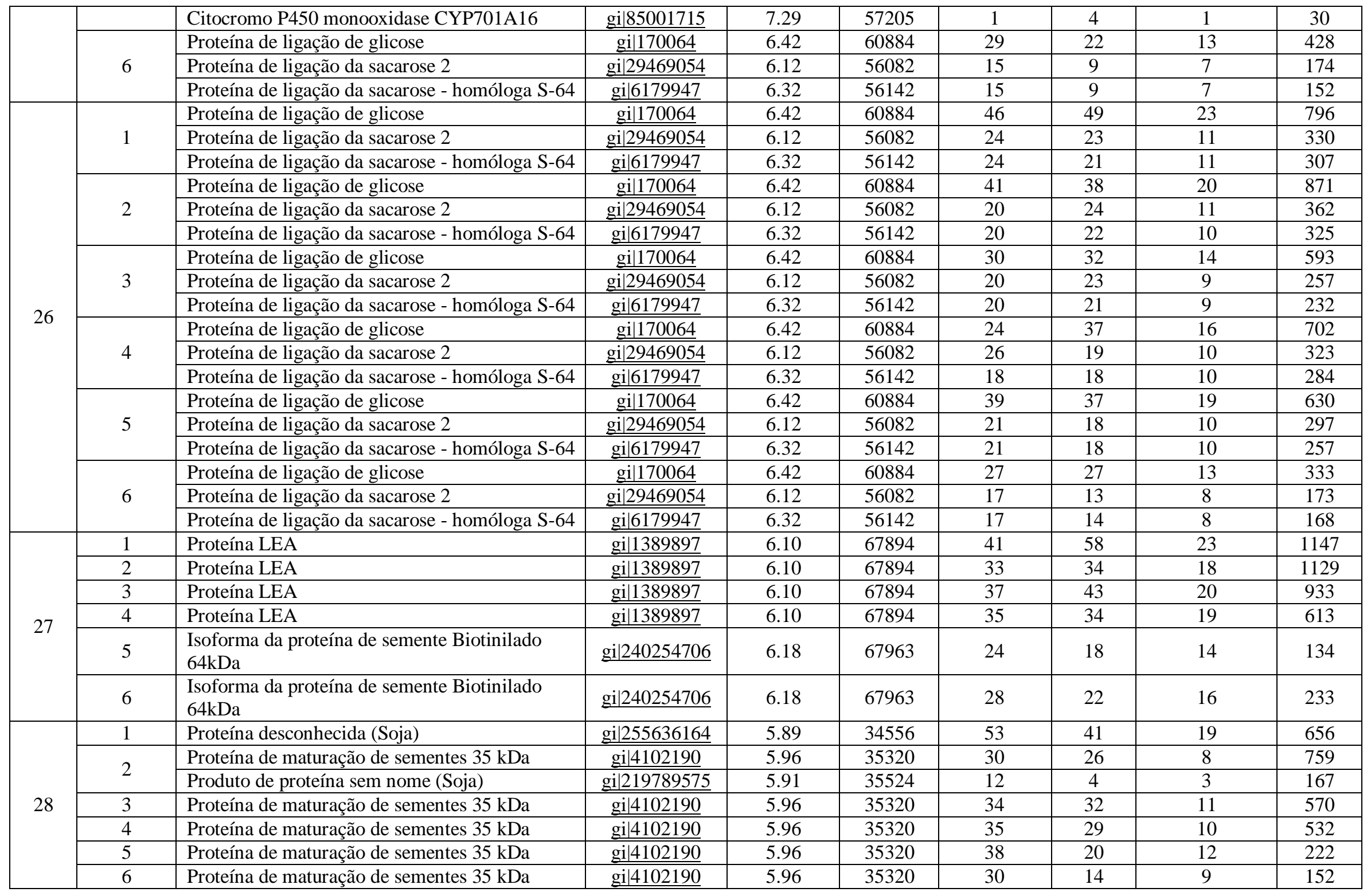




\begin{tabular}{|c|c|c|c|c|c|c|c|c|c|}
\hline \multirow{12}{*}{29} & \multirow{2}{*}{1} & Subunidade G2 Glicinina & gi|18637 & 5.46 & 54927 & 24 & 36 & 9 & 1807 \\
\hline & & Subunidade A3 Glicinina & gi| 121280 & 5.60 & 58377 & 6 & 25 & 3 & 798 \\
\hline & 2 & Subunidade G2 Glicinina & gi|18637 & 5.46 & 54927 & 9 & 11 & 4 & 736 \\
\hline & \multirow{3}{*}{3} & Subunidade G2 Glicinina & \begin{tabular}{l|l|} 
gi 18637 \\
\end{tabular} & 5.46 & 54927 & 27 & 34 & 10 & 1259 \\
\hline & & Subunidade G1 Glicinina & gi 18635 & 5.89 & 56299 & 16 & 13 & 6 & 254 \\
\hline & & Subunidade G3 Glicinina & \begin{tabular}{l|l|} 
gi 18639 \\
\end{tabular} & 5.73 & 54835 & 9 & 6 & 3 & 176 \\
\hline & \multirow{2}{*}{4} & Subunidade G2 Glicinina & gi 18637 & 5.46 & 54927 & 27 & 48 & 10 & 1932 \\
\hline & & Subunidade G1 Glicinina & gi| 18635 & 5.89 & 56299 & 17 & 18 & 7 & 259 \\
\hline & \multirow{2}{*}{5} & Subunidade G2 Glicinina & \begin{tabular}{l|l} 
gi 18637 \\
\end{tabular} & 5.46 & 54927 & 29 & 41 & 10 & 1316 \\
\hline & & Subunidade G1 Glicinina & gi 18635 & 5.89 & 56299 & 9 & 11 & 5 & 212 \\
\hline & & Produto de proteína sem nome (Soja) & gi 18609 & 5.56 & 54869 & 27 & 24 & 9 & 711 \\
\hline & 6 & Subunidade G1 Glicinina & gi 18635 & 5.89 & 56299 & 10 & 9 & 5 & 191 \\
\hline \multirow{11}{*}{30} & \multirow{2}{*}{1} & Subunidade G2 Glicinina & gi| 18637 & 5.46 & 54927 & 19 & 32 & 8 & 1107 \\
\hline & & Subunidade G1 Glicinina & gi 18635 & 5.89 & 56299 & 10 & 5 & 3 & 132 \\
\hline & 2 & Glicinina & \begin{tabular}{l|l} 
gi & 18609 \\
\end{tabular} & 5.56 & 54869 & 25 & 26 & 8 & 940 \\
\hline & \multirow{2}{*}{3} & Subunidade G2 Glicinina & \begin{tabular}{l|l|l|} 
gi & 18637 \\
\end{tabular} & 5.46 & 54927 & 20 & 33 & 8 & 1526 \\
\hline & & Subunidade G1 Glicinina & gi| 18635 & 5.89 & 56299 & 10 & 16 & 5 & 370 \\
\hline & \multirow{2}{*}{4} & Subunidade G2 Glicinina & \begin{tabular}{l|l|} 
gi 18637 \\
\end{tabular} & 5.46 & 54927 & 25 & 38 & 9 & 1618 \\
\hline & & Subunidade G1 Glicinina & \begin{tabular}{l|l} 
gi & 18635 \\
\end{tabular} & 5.89 & 56299 & 17 & 17 & 7 & 253 \\
\hline & \multirow{2}{*}{5} & Subunidade G2 Glicinina & gi 18637 & 5.46 & 54927 & 29 & 39 & 10 & 1171 \\
\hline & & Subunidade G1 Glicinina & gi| 18635 & 5.89 & 56299 & 10 & 13 & 6 & 208 \\
\hline & \multirow{2}{*}{6} & Subunidade G2 Glicinina & \begin{tabular}{l|l} 
gi & 18637 \\
\end{tabular} & 5.46 & 54927 & 26 & 31 & 9 & 883 \\
\hline & & Subunidade G1 Glicinina & gi| 18635 & 5.89 & 56299 & 13 & 11 & 6 & 239 \\
\hline \multirow{13}{*}{31} & \multirow{2}{*}{1} & Subunidade G2 Glicinina & gi 18637 & 5.46 & 54927 & 21 & 38 & 9 & 1436 \\
\hline & & Subunidade G3 Glicinina & gi 18639 & 5.73 & 54835 & 11 & 10 & 4 & 360 \\
\hline & \multirow{2}{*}{2} & Produto de proteína sem nome (Soja) & gi|18609 & 5.56 & 54869 & 20 & 18 & 7 & 572 \\
\hline & & Subunidade G1 Glicinina & gi 18635 & 5.89 & 56299 & 13 & 12 & 8 & 220 \\
\hline & \multirow{3}{*}{3} & Subunidade G2 Glicinina & gi 18637 & 5.46 & 54927 & 25 & 28 & 9 & 989 \\
\hline & & Subunidade G3 Glicinina & gi| 18639 & 5.73 & 54835 & 9 & 11 & 3 & 283 \\
\hline & & Subunidade G1 Glicinina & gi| 18635 & 5.89 & 56299 & 22 & 25 & 9 & 279 \\
\hline & \multirow{2}{*}{4} & Subunidade G2 Glicinina & \begin{tabular}{l|l|} 
gi 18637 \\
\end{tabular} & 5.46 & 54927 & 29 & 34 & 10 & 1224 \\
\hline & & Subunidade G1 Glicinina & gi 18635 & 5.89 & 56299 & 18 & 43 & 10 & 644 \\
\hline & \multirow{2}{*}{5} & Subunidade G2 Glicinina & gi|18637 & 5.46 & 54927 & 29 & 24 & 10 & 730 \\
\hline & & Subunidade G1 Glicinina & gi 18635 & 5.89 & 56299 & 15 & 18 & 8 & 226 \\
\hline & \multirow{2}{*}{6} & Subunidade G2 Glicinina & gi| 18637 & 5.46 & 54927 & 25 & 28 & 9 & 661 \\
\hline & & Subunidade G1 Glicinina & gi 18635 & 5.89 & 56299 & 17 & 19 & 9 & 269 \\
\hline 32 & 1 & Produto de proteína sem nome (Soja) & gi|18609 & 5.56 & 54869 & 23 & 21 & 7 & 869 \\
\hline
\end{tabular}




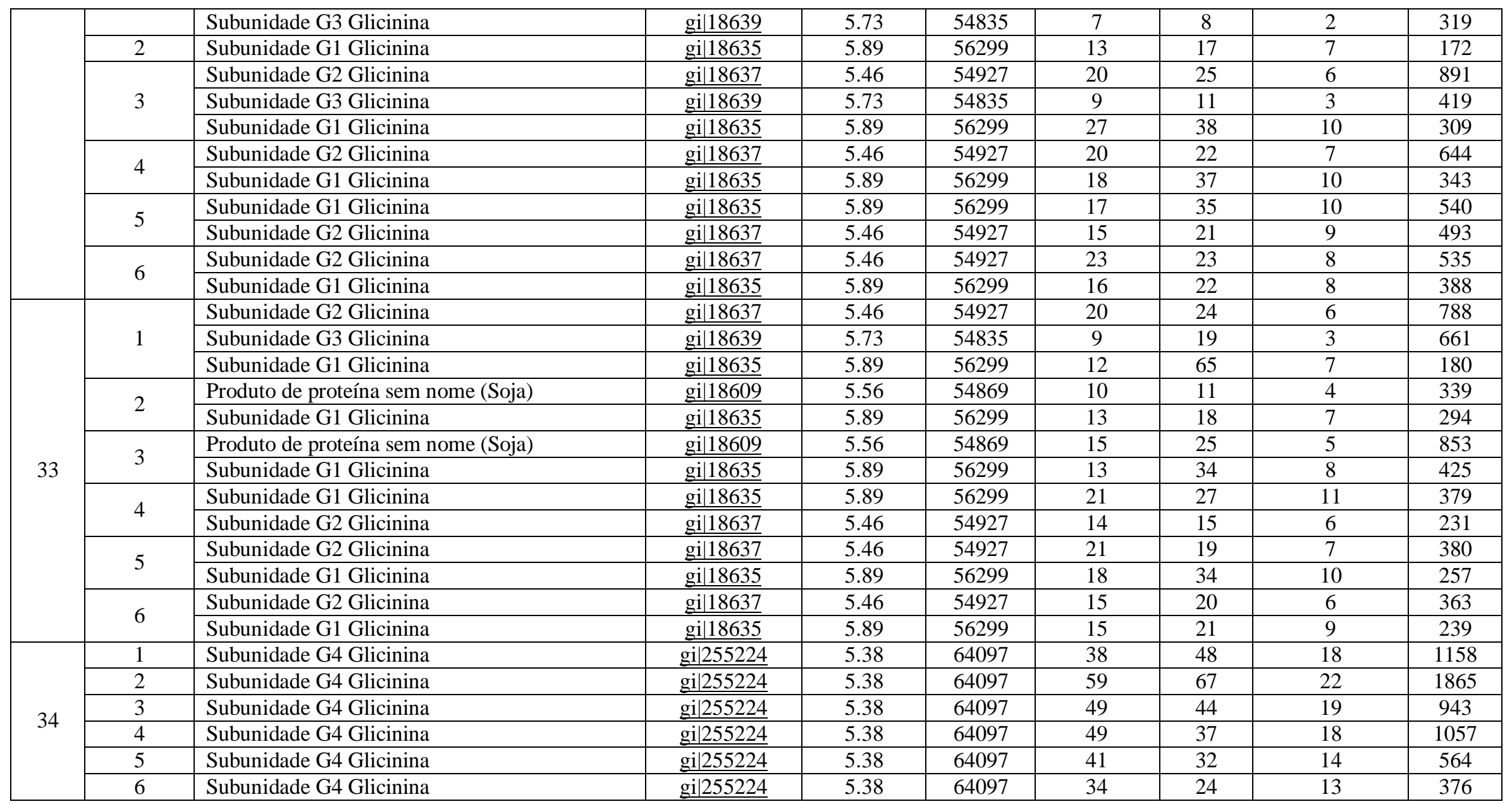


De uma maneira geral, obtivemos resultados precisos e satisfatórios, com scores muito além do indicado como valor mínimo de garantia de identidade e homologia das proteínas.

Como nosso principal objetivo é a caracterização das diferenças nos perfis protéicos entre amostras GMs e não GMs, comparamos as proteínas identificadas nas amostras 1, 3 e 5, as amostras convencionais genitoras, com as amostras 2, 4 e 6, amostras GMs derivadas das anteriores. Foram identificados os perfis protéicos das amostras de soja e avaliadas possíveis variações na expressão de inibidores de proteases e fatores antinutricionais. Para esta etapa escolhemos spots dos principais grupos protéicos e também pequenos grupos que pudessem trazer tais características negativas ao consumidor.

Na soja, cerca de $40 \%$ da sua composição corresponde a proteínas e destas, $70 \%$ correspondem às proteínas de reserva glicinina e $\beta$-conglicinina (KRISHNAN et al., 2007; L'HOCINE; BOYE; JOUVE, 2007). Estes dois grandes grupos protéicos foram identificados pelos spots 1, 2, 4, 5, 6, 7, 8, 9, 10, 16, 17, 18, 19, 29, 30, 31, 32, 33 e 34 .

A $\beta$-conglicinina é a segunda proteína de reserva mais abundante na soja, é uma proteína trimérica, composta pelas subunidades alfa' $(\alpha$ '), alfa $(\alpha)$ e beta $(\beta)$ (THANH; SHIBASAKI, 1978). Pelo seu coeficiente de sedimentação é conhecida como 7S, que compreende 35\% das proteínas solúveis da soja (SHEWRY; NAPIER; TATHAM, 1995).

Para os spots 1 e 2, que correspondem as subunidades $\alpha$ e $\alpha^{\prime}$ da $\beta$-conglicinina os resultados não diferiram entre as amostras GMs e não GMs e foi reconhecida apenas 1 proteína para cada spot. Para os spots 4, 5, 6, 7 e 8 que correspondem a fração $\beta$ da $\beta$ conglicinina, foram identificadas 4 proteínas, duas frações $\beta$ da $\beta$-conglicininas, um precursor da $\beta$ da $\beta$-conglicinina e ainda foi identificada uma estrutura semelhante à proteína recombinante cristalina e nativa da $\beta$-conglicinina complexada com $\mathrm{N}$-acetil-D-glucosamina, depositada em banco de dados e que pode ser visualizada na figura 31. 


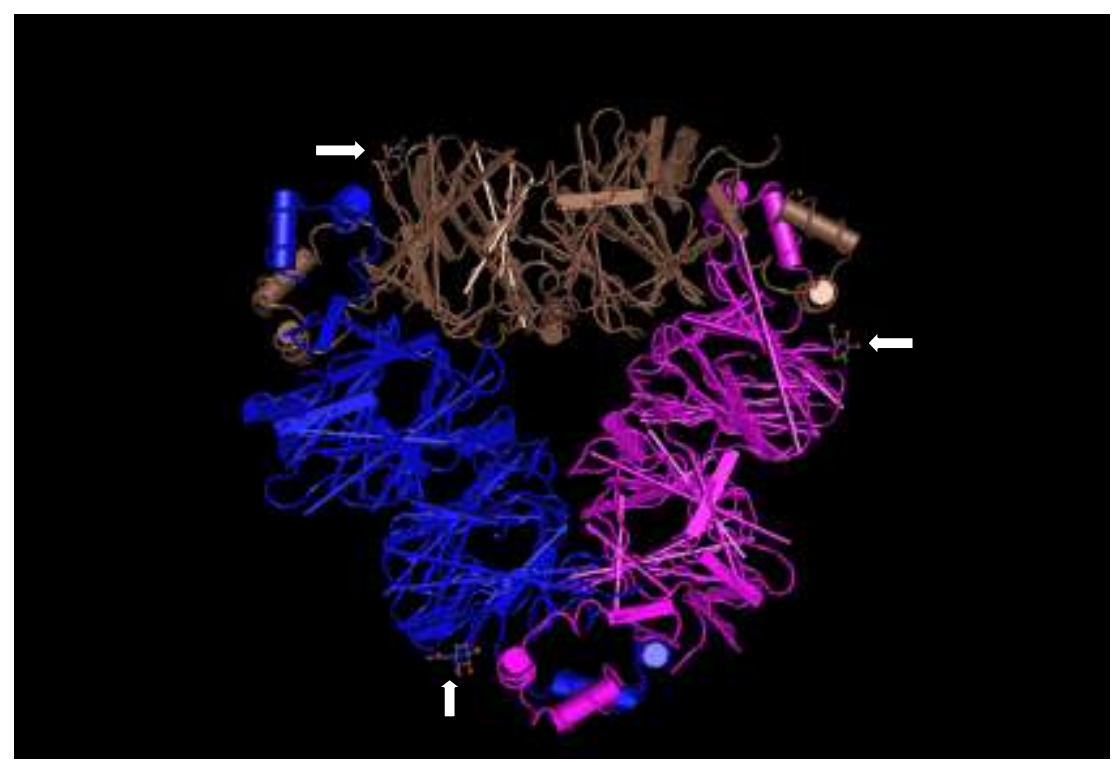

Figura 31: Estrutura recombinante cristalina e nativa da $\beta$-conglicinina complexada com N-acetil-Dglucosamina, número de acesso ao NCBI: gi|21465628. Na figura é possível observar a estrutura trimérica da $\beta$ conglicinina e também as estruturas químicas da glucosaminas complexadas apontadas pelas setas. Fonte NCBI.

As identificações das subunidades $\alpha$, $\alpha^{\prime}$ e $\beta$ da $\beta$-conglicinina corroboram com dados da literatura (HERMAN et al., 2003; BATISTA et al., 2007, NATARAJAN et al., 2006, KRISHNAN et al, 2005).

A glicinina é a proteína de reserva mais abundante da soja e é formada por 6 subunidades, destas apenas 5 foram identificadas até o momento e são as subunidades G1, G2, G3, G4 e G5. Elas são formadas por duas ou três cadeias ácidas e básicas que são clivadas pós-tradução. Com base na homologia de suas sequências de aminoácidos, estas 5 subunidades são classificadas em 2 grupos: grupo I consiste em G1, G2 e G3 e o grupo II consiste em G4 e G5 (NATARAJAN et al., 2007 ${ }^{\mathrm{A}}$ ).

A glicinina e suas respectivas subunidades correspondem aos spots 9, 10, 16, 17, $18,19,23,29,30,31,32,33$ e 34 . Na fração ácida da glicinina, que corresponde os spots 9 , $10,16,17,18$ e 23 identificamos 2 proteínas correspondentes a glicinina e algumas proteínas correspondentes as subunidades G1, G2, G3, G4 e A3 e precursor da subunidade G3. A fração básica da glicinina, que corresponde os spots 29, 30, 31, 32, 33 e 34 foram reconhecidas as subunidades G1, G2, G3, G4 e A3B4. A fração A3B4, que corresponde a fração G5, foi identificada apenas na amostra 4, que é geneticamente modificada. Mesmo assim, a frequiência de reconhecimento das subunidades protéicas da glicinina foi semelhante entre as amostras GMs e não GMs. 
Natarajan e colaboradores $\left(2007^{\mathrm{A}}\right)$ investigaram as variações proteômicas e genômicas da glicinina em 16 amostras de soja, para isso avaliaram as variações das subunidades G1, G2, G3, G4 e G5. Perceberam maiores variações entre as frações ácidas de G3, G4 e G5.

O curioso foi que Natarajan et al $\left(2007^{\mathrm{A}}\right)$ não conseguiu identificar a subunidade G1 na fração ácida e nós obtivemos este resultado. A fração G5 (também conhecida como A3B4) apresentou-se sutilmente em nossos resultados, apenas para uma amostra e na fração ácida. Entretanto, os autores, identificaram a subunidade G5 tanto na fração ácida como na básica (NATARAJAN et al., 2007 ${ }^{\mathrm{A}}$ ). Batista et al (2007) também não observaram a subunidade G5.

Em 2006, o primeiro desses grupos de pesquisadores fizera uso das ferramentas proteômicas para uma abordagem combinada de separação e identificação das duas principais proteínas de armazenamento da soja em amostras selvagem e convencional. Os nossos resultados foram semelhantes aos deles, com a identificação das frações $\alpha, \alpha^{\prime}$ e $\beta$ da $\beta$ conglicinina e subunidades G1, G2, G3, G4 e G5 das frações ácidas e básicas de glicinina (NATARAJAN et al., 2006).

Para a amostra 4 foi identificado no spot 10, além de uma fração ácida da glicinina e uma protease, uma estrutura recombinante cristalina subunidade pro-glicinina A3b4, também conhecida como subunidade G5. Esta pro-glicinina pode ser visualizada na Figura 32.

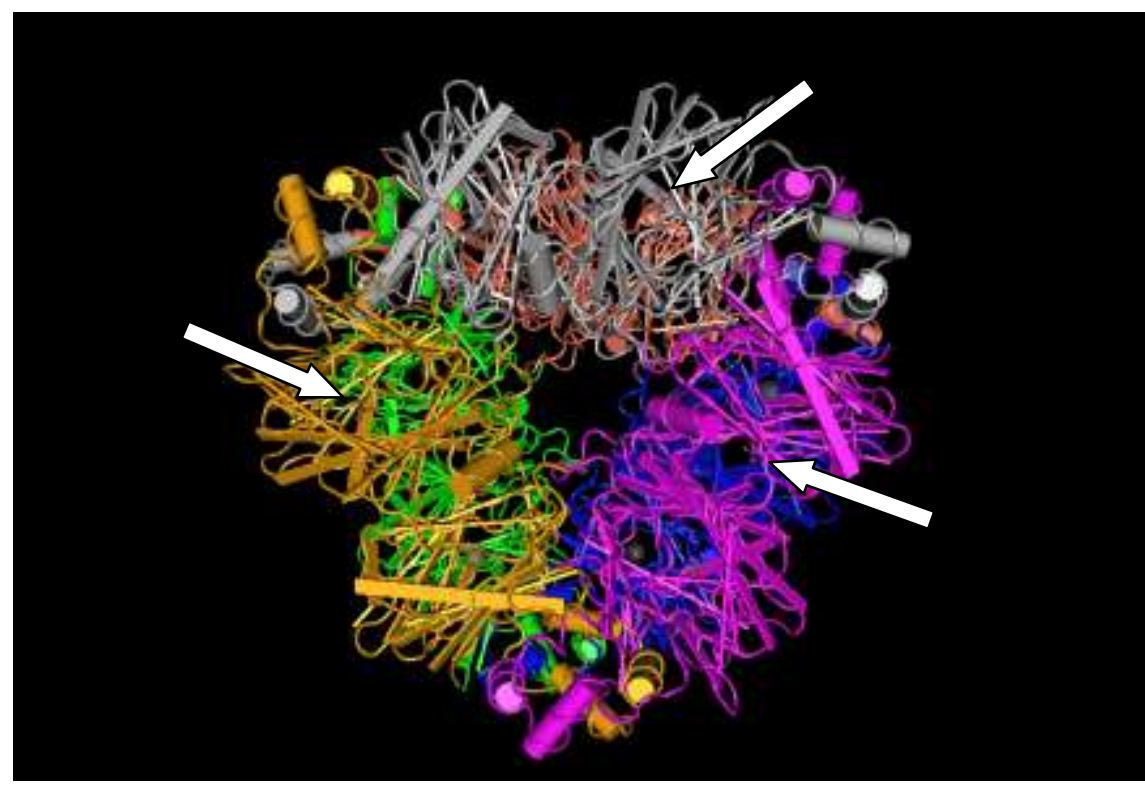

Figura 32: Estrutura recombinante cristalina subunidade Pro-glicinina A3b4. Número de acesso no NCBI: gi|119389108. Na figura é possível observar a estrutura hexamérica da glicinina e alguns açucares ligados na cadeia apontados pelas setas. Fonte NCBI. 
Existem esforços por parte das pesquisas para o aumento do teor protéico dos grãos de soja. Krishnan e cols (2007) compararam os perfis protéicos de sojas comerciais normais e de transgenes com alta concentração de proteínas (cerca de 50\%) por 2D associada a espectrometria de massas. Detectaram que as sementes com altas concentrações de proteínas são compostas por acúmulos das proteínas de reserva ( $\beta$-conglicinina e glicinina) presumivelmente mediada pela expressão diferenciada destes genes durante o desenvolvimento da semente (KRISHNAN et al., 2007).

Ainda na fração ácida da glicinina, além das subunidades, identificamos também uma protease tiol $34 \mathrm{kDa}$ associada a maturação das sementes, também conhecida como P34, tanto para as amostras GMs quanto não GMs.

Trata-se de uma protease que pertence à superfamília papaína. Nas células vegetais, apresenta-se associada a frações lipídicas e localiza-se no interior de vacúolos de proteínas de armazenamento (SEWEKOW et al., 2008; KALINSKI et al., 1992). Muitas proteases tióis estão associadas à germinação, ou seja, na degradação protéica e mobilização de proteínas para o desenvolvimento da planta. Porém, esta se mostrou acumular durante a maturação das sementes (KALINSKI et al., 1992).

A P34 é reportada como uma dos principais alérgenos da soja em seres humanos sensíveis e corresponde a cerca de 2-3\% das proteínas da soja (HERMAN et al., 2003, SEWEKOW et al., 2008). Apresenta peso molecular de 28,643 Da e na forma glicosilada, a massa é ligeiramente maior, apresentando uma banda de 32kDa em géis SDS-PAGE (SEWEKOW et al., 2008).

No trabalho de Herman e colaboradores (2003), eles justamente criam um transgene induzindo o silenciamento gênico para evitar a acumulação da P34 nas sementes, com o intuito de eliminar este alérgeno dominante da soja. Perceberam que nas plantas P34 silenciadas, suas sementes não tinham quaisquer alterações na composição, desenvolvimento, diferenças fenotípicas, quando comparadas com as plantas controles, esses dados forneceram evidências de equivalência substancial entre as amostras estudadas (HERMAN et al., 2003).

No spot 12 identificamos 2 proteínas, a dehidrina e uma proteína associada a maturação das sementes que apresentava peso molecular semelhante. Para o spot 27 identificamos a proteína LEA (Late embryogenesis abundant - embriogênese tardia abundante) nas amostras 1, 2, 3 e 4 e nas amostras 5 e 6 reconhecemos uma isoforma da proteína Biotinilada. 
As proteínas LEA formam um grupo, do qual a dehidrina faz parte, ambas apresentam características anfipáticas, atuando na proteção das estruturas citoplasmáticas durante a desidratação, inibindo a desnaturação de macromoléculas e estabilizando estruturas celulares sob estresse hídrico severo (SILVA, 2006). Apresentam caráter básico, resistência ao calor e estão livres de cisteínas e triptofano (SAMARAH et al., 2006).

Estes últimos autores avaliaram a acumulação de dehidrina durante o desenvolvimento de sementes de soja, sob condições normais e sobre estresse hídrico. A dehidrina foi detectada nos dois ensaios, porém, sob estresse hídrico, foi detectadas precocemente, caracterizando que as mesmas apresentam um papel de tolerância à seca em sementes em desenvolvimento (SAMARAH et al., 2006).

Zolla e colaboradores (2007) compararam grupos selvagens e transgênicos de milho através de ferramentas proteômicas e também detectaram as proteínas dehidrina e LEA e as caracterizaram como proteínas protetoras das sementes em casos de desidratação.

No spot 28 foi identificada a proteína relacionada à maturação das sementes.

As proteínas LEA e dehidrina além da função de proteção a situações de desidratação são expressas normalmente nas fases de maturação das sementes, assim como as proteínas biotiniladas e as identificadas como proteínas de maturação das sementes.

Para o spot 13 encontramos 2 produtos protéicos sem denominação e apenas na amostras 5 conseguimos identificar a Globulina 7S fração básica, que era o esperado por comparações com outros trabalhos. Essa falta de identificação se deve ao fato desta proteína aparecer em baixa intensidade e difícil visualização o que possivelmente causou uma excisão errônea.

Identificamos no spot 14 para todas as amostras o fragmento 1 da proteína álcool desidrogenase. A álcool desidrogenase é uma enzima relacionada à respiração anaeróbia das plantas. Fante e colaboradores (2009) analisaram amostras de soja que sofreram deficiência de oxigênio por excesso de água, e verificaram maior atividade da enzima álcool desidrogenase nesta situação. Com o metabolismo anaeróbio, as plantas convertem piruvato e acetaldeído em substâncias tóxicas como etanol e o lactato, podendo causar um baixo rendimento energético das sementes (FANTE et al., 2009). Batista e colaboradores (2007) também reconheceram esta proteína nas suas amostras.

A álcool desidrogenese, por se tratar de uma proteína amplamente distribuída nas plantas, também foi reportada por Corpillo e colaboradores (2004) na investigação da 
utilização do conceito de equivalência substancial e proteômica, quando comparou tomates GMs e suas estirpes genitoras (CORPILLO et al., 2004).

No spot 15 identificamos a Aglutinina de soja complexada com açúcar. Como já citado anteriormente, as aglutininas representam um fator antinutricional por diminuir a qualidade protéica do grão de soja, podendo se ligar a carboidratos e glicoconjugados sobre a superfície epitelial do intestino, interferindo com na absorção de nutrientes (GEORGE et al., 2008; LAJOLO; GENOVESE, 2002).

Os demais trabalhos sobre perfis proteômicos da soja também reconheceram tal fator antinutricional em suas amostras (BATISTA et al., 2007; HERMAN et al., 2003).

O farelo de soja é uma excelente fonte de proteínas para animais e humanos, porém, devido ao seu conteúdo antinutricional, este só pode ser consumido após processamento. Ensaios para a eliminação das aglutininas de produtos que podem ser consumidos in natura, como o farelo de soja, são realizados para reduzir gastos das indústrias de processamento. George e colaboradores (2008) objetivaram induzir mutações em cultivares de soja para baixar o conteúdo de lectina a fim de reduzir os gastos da indústria. Conseguiram tal feito, o conteúdo de lectina tornou-se muito baixo e o desenvolvimento da semente continuou normal, indicando que não houve impactos negativos sobre o crescimento da planta e no teor de proteínas (GEORGE et al., 2008).

Na Figura 33 esta representada a aglutinina de soja que foi encontrada em nossas amostras, aqui complexada com 2,6 pentasacarídeo.

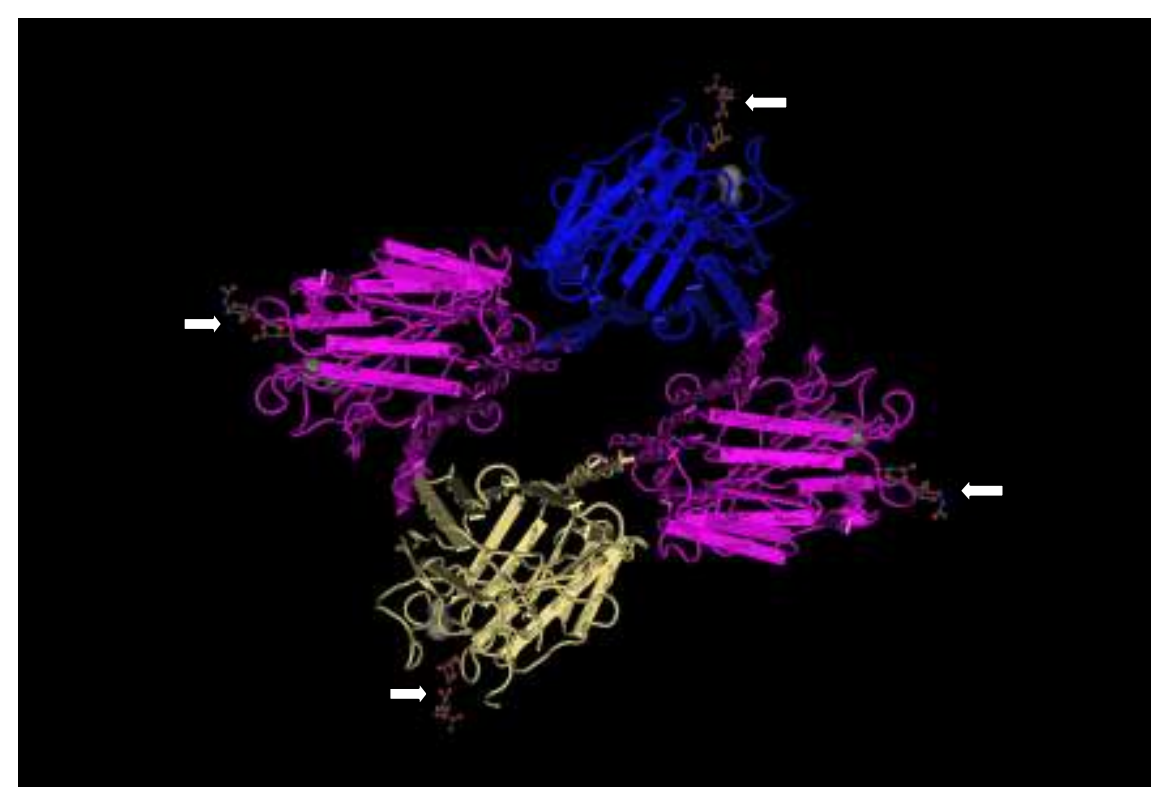


Figura 33: Aglutinina de soja complexada com 2,6 pentasacarídeo. Número de acesso no NCBI: gi|6729836. Na figura é possível observar as 4 frações que compõem a aglutinina e os açucares que estão complexados na molécula apontados pelas setas. Fonte: NCBI.

Para os spots 20 e 21, identificamos alguns inibidores de proteases, entre eles, Inibidor de tripsina TIA, Inibidor de tripsina Kunitz KTI1, Inibidor de tripsina subtipo A, Inibidor de tripsina Kunitz KTI2 e precursor do Inibidor de tripsina Kunitz KTI2.

Os inibidores de proteases, assim como a aglutinina de soja, são fatores antinutricionais. $\mathrm{O}$ inibidor de tripsina bloqueia a ação da tripsina resultando em aumento excessivo da concentração plasmática do hormônio colecistoquinina, e desta forma, o pâncreas é continuamente estimulado a liberar mais enzima, podendo provocar hipertrofia pancreática (FRIEDMAN; BRANDON, 2001; CARDOSO et al., 2007).

Os estudos existentes sobre hipertrofia pancreática em animais são divergentes e antigos, entre os resultados, encontram-se aumento do número e/ou aumento do tamanho das células pancreáticas e ainda aumento do pâncreas (SILVA; SILVA, 2000).

Para a planta, os inibidores de proteases atuam como uma defesa rápida contra ataques de herbívoros, inibindo as proteases digestivas do inseto, podendo aumentar a mortalidade (MAJOR; CONSTABEL, 2008).

Em contra partida, os efeitos benéficos das KTIs também são reportados. Kobayashi e colaboradores (2004), inspirados em outros estudos relacionados, isolaram KTI de soja e avaliaram seu desempenho no combate ao câncer ovariano e os resultados foram positivos, relataram pela primeira vez, uma inibição da invasividade celular, através da supressão de um fator da cascata de sinalização (uPA) (KOBAYASHI et al., 2004).

A expressão destes 5 peptídeos identificados como inibidores de tripsina foram semelhantes nas amostras GMs e não GMs.

Natarajan e colaboradores $\left(2007^{\mathrm{B}}\right)$ investigaram os perfis proteômicos e genômicos de inibidores de proteases em 16 genótipos de soja, entre amostras selvagens e cultivadas em distintos locais. Eles identificaram duas proteínas entre os cultivares selvagens e cultivados: KTI2 e KTI3. Estas duas proteínas estavam presentes em todas as amostras.

Em nossos resultados, não identificamos KTI3. A proteína KTI2 identificada por Natarajan e cols. $\left(2007^{\mathrm{B}}\right)$ corresponde à proteína identificada em nosso trabalho como KTI1, isso comparando o número de acesso ao NCBI fornecido pelos autores (gi|125722).

A inibição dos fatores antinutricionais da soja é realizado com tratamentos térmicos adequados em muitos casos, porém são necessários cuidados para não destruir 
aminoácidos importantes ou comprometer a biodisponibilidade de outros nutrientes (MONTEIRO et al., 2004).

Os efeitos de autoclavagem sobre a qualidade protéica de farinhas de soja convencionais e uma isolinha GM livre de KTI e lectina foram avaliados por Machado e cols. (2008). A amostra GM apresentou menor nível de inibição tríptica e não apresentou atividade hemaglutinante, comparada com a farinha convencional. Quinze minutos de aquecimento foram suficientes para reduzir mais de $90 \%$ do KTI, lectina e uréase. Os autores reportam que a qualidade nutricional das farinhas GMs e não GMs mostraram-se semelhantes (MACHADO et al., 2008).

Inibidores do tipo Kunitz também foram encontrados por Lehesranta e colaboradores (2005) quando avaliaram a variação de nutrientes essenciais e fatores antinutricionais em batatas geneticamente modificadas em comparação com convencionais.

Nos spots 24, 25 e 26 foram identificadas 1 proteína de ligação de glicose e 2 proteínas de ligação de sacarose em todas as amostras. Para amostra 5 identificamos também a proteína Citocromo P450 monooxidase.

As proteínas ligantes de açúcar também foram reportadas por outros estudiosos sobre proteômica de soja (BATISTA et al., 2007; HERMAN et al., 2003).

Este grupo de peptídeos ligante de açúcar parece estar envolvido em mecanismos de regulação e translocação de carbono e açucares para processos de crescimento e desenvolvimento das plantas (WACLAWOSKY et al., 2006; OVERVOORDE; FROMMER; GRIMES, 1996).

O complexo enzimático citocromo $\mathrm{P} 450$ participa do metabolismo da planta, com função de detoxificação de certos compostos através de reações de oxidação. Encontra-se em distintas organelas e em baixas concentrações, desempenha função de biossíntese de diversos compostos como ácidos graxos, alcalóides e terpenos, participando na defesa da planta com a produção de metabólitos e transformação de herbicidas (MENDOZA et al., 2009). Os inseticidas organofosforados são capazes de inibir o citocromo P450 (TREZZI et al., 2009).

Além de amplos estudos das sementes de soja citados no decorrer do trabalho, as identificações por 2D associada a espectrometria de massas também são exploradas para outras partes da planta. Xu e colaboradores (2006) realizaram a separação e identificação protéica das folhas de soja, na tentativa de estabelecer um mapa proteômico de referência. As proteínas identificadas são distintas das encontradas no presente trabalho. 
As ferramentas proteômicas também são reportadas para a investigação de outras alimentos sobre diferentes aspectos como pesquisa das proteínas alergênicas do leite (NATALLE et al., 2005) e comparações entre alimentos geneticamente modificados e convencionais além da soja, como milho (ALBO et al., 2007), batata (LEHESRANTA et al., 2005) e tomate (CORPILLO et al., 2004), etc.

De uma maneira geral, os peptídeos identificados entre as amostras GMs e não GMs não difeririam entre si e apresentaram-se dentro do esperado por consultas anterior a literatura. A Figura 34 mostra de uma maneira compilada os principais peptídeos expressos e identificados em nossas amostras.

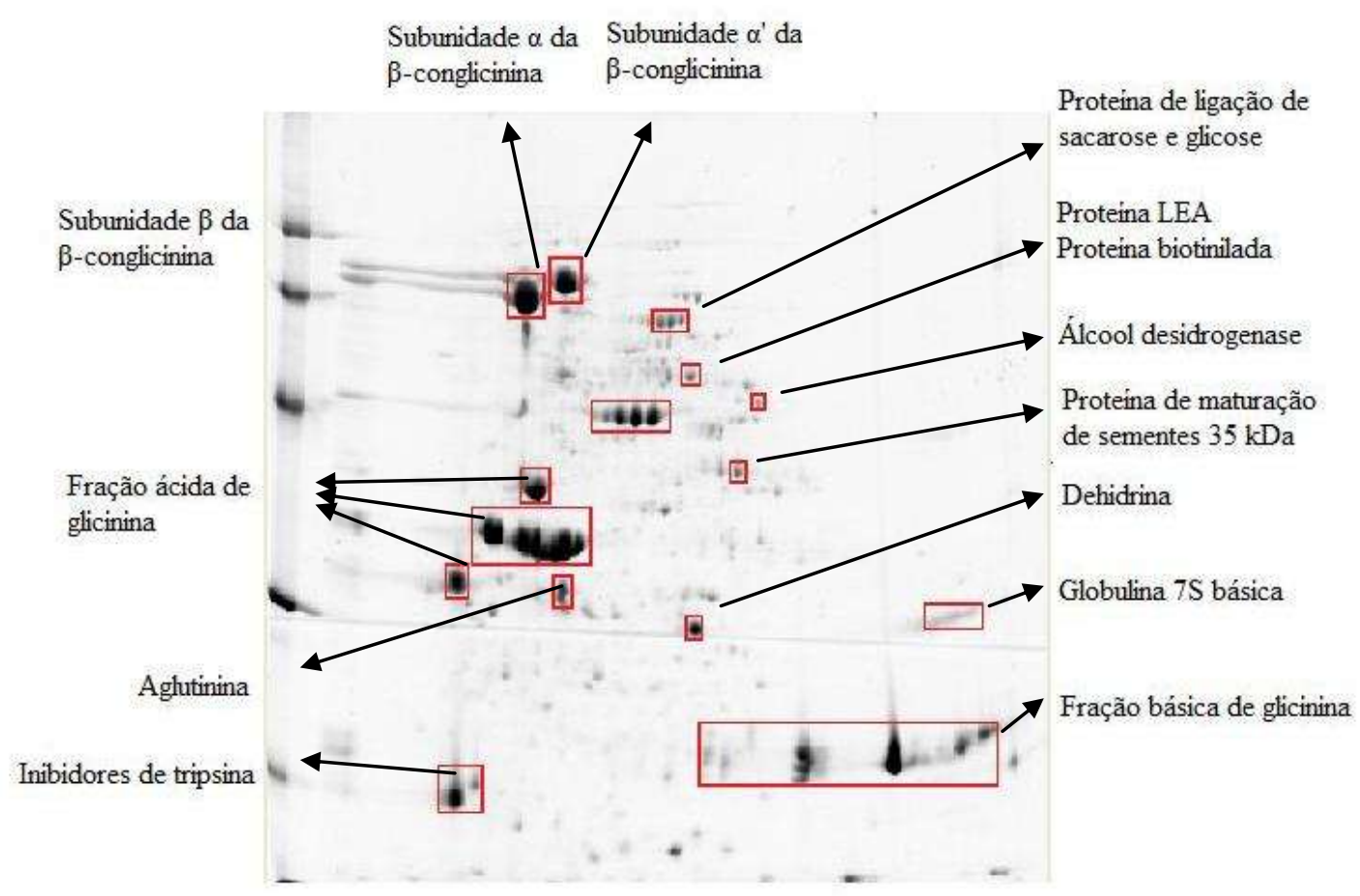

Figura 34: Gel bi-dimensional representando o mapa protéico identificado por espectrometria de massas.

\subsubsection{Identificação das proteínas das amostras orgânicas por espectrometria de massas}

Para as amostras orgânicas, selecionamos 7 spots de cada amostra, totalizando 14. Os spots receberam as mesmas denominações dos selecionados para as demais amostras, e são os spots: $1,10,12,15,20,22$ e 25 . Os resultados obtidos por espectrometria de massas para as amostras orgânicas estão expostos na Quadro 2. 
Os resultados das identificações por espectrometria de massas para os spots das amostras orgânicas foram semelhantes aos encontrados nas amostras convencionais e GMs. O único spot que se diferenciou foi o spot 22 da amostra 2 orgânica. Neste, assim como em todos os spots 22 das outras amostras, esperávamos reconhecer a proteína lipoxigenase (LOX), porém, devido a baixa concentração não conseguimos identificá-la. Para as demais amostras, inclusive na amostra 1 orgânica, identificamos a mesma sequência protéica sem denominação (gi|18536).

As LOX encontram-se em baixa concentração, correspondendo a cerca de $1 \%$ das proteínas da soja (MONTEIRO et al. 2004).

Herman e colaboradores (2003) identificaram a lipoxigenase.

As LOXs, apesar de não ser um fator antinutricional, são isoenzimas responsáveis pelo beany flavor, característica da soja identificada pelo sabor e aroma desagradável ao paladar de muitos consumidores, principalmente ocidentais (BARROS et al., 2007). As LOX são responsáveis por catalisar a adição de oxigênio aos ácidos graxos poliinsaturados, formando hidroperóxidos de ácidos graxos que por reações subseqüientes produzem aldeídos e cetonas de cadeia curta que se ligam as frações protéicas, reações essas que formam o beany flavor (AXEROLD; CHEESBROUGH; LAAKSO, 1981).

A identificação da proteína lipoxigenase apenas para uma amostra orgânica e não para amostras GMs e convencionais, corrobora com a suposição de que com a forma de cultivo orgânico, os mecanismos de defesa das plantas estão mais presentes, já que os defensivos químicos não são empregados, e consequentemente a planta produz seus elementos de defesa. Essa questão já foi argumentada por Magkos e cols (2003), trabalho no qual sugeriu que a produção de toxinas naturais é reprimida na presença de produtos químicos sintéticos, enquanto é induzida na ausência deles, a fim de manter a integridade defensiva da planta (MAGKOS; ARVANITI; ZAMPELAS, 2003).

As amostras orgânicas foram introduzidas neste estudo a partir dos resultados comparativos iniciais entre as variedades convencionais e GM, que indicaram pequenas diferenças não significativas nos mapas proteicos nos mapas proteicos de ambos os grupos. Desse modo, além de serem de linhagens distintas, as sojas orgânicas não são submetidas aos defensivos agrícolas, o que poderia permitir uma avaliação do papel destes compostos no proteoma de sementes maduras. No entanto, os resultados mostraram que não houve indução diferenciada relevante de novas proteínas em relação às amostras genitoras e GM, ou mesmo a intensificação de spots relativos aos fatores antinutricionais. A revelação de uma lipoxigenase, em uma das duas amostras de soja orgânica, não se caracteriza como tendência 
de proteção sistêmica da planta a fatores adversos em grãos obtidos por esta prática de cultivo.

Quadro 2: Proteínas identificadas por espectrometria de massas das amostras orgânicas.

\begin{tabular}{|c|c|c|c|c|c|c|c|c|c|}
\hline Spot & Amostra & Proteína identificada & $\begin{array}{l}\text { Número de } \\
\text { acesso no } \\
\text { NCBI }\end{array}$ & $\begin{array}{c}\text { Ponto } \\
\text { isoelétrico }\end{array}$ & $\begin{array}{c}\text { Massa } \\
\text { nominal }\end{array}$ & $\begin{array}{c}\text { Cobertura } \\
\text { de } \\
\text { sequência }\end{array}$ & Macths & $\begin{array}{l}\text { Seqüências } \\
\text { reconhecidas }\end{array}$ & Score \\
\hline \multirow[t]{3}{*}{1} & \multirow[t]{2}{*}{1} & Subunidade $\alpha$ da $\beta$-conglicinina & gi|9967357 & 4.92 & 63184 & 31 & 51 & 18 & 1418 \\
\hline & & Subunidade $\alpha^{\prime}$ da $\beta$-conglicinina & gi|9967361 & 5.23 & 65160 & 13 & 19 & 7 & 765 \\
\hline & 2 & Subunidade $\alpha$ da $\beta$-conglicinina & gi|9967357 & 4.92 & 63184 & 28 & 39 & 15 & 1178 \\
\hline \multirow[t]{4}{*}{10} & \multirow[t]{2}{*}{1} & Glicinina & gi|18641 & 5.21 & 64351 & 21 & 38 & 10 & 1845 \\
\hline & & Subunidade A3 Glicinina & gi|121280 & 5.6 & 58377 & 4 & 12 & 3 & 812 \\
\hline & \multirow[t]{2}{*}{2} & Glicinina & gi|18641 & 5.21 & 64351 & 19 & 29 & 9 & 928 \\
\hline & & Subunidade G2 Glicinina & gi| 18637 & 5.46 & 54927 & 19 & 17 & 8 & 595 \\
\hline \multirow[t]{2}{*}{12} & 1 & Proteína associada à maturação & gi| 170024 & 6.07 & 23700 & 71 & 28 & 11 & 604 \\
\hline & 2 & Proteína associada à maturação & gi| 170024 & 6.07 & 23700 & 54 & 19 & 12 & 594 \\
\hline \multirow[t]{2}{*}{15} & 1 & $\begin{array}{l}\begin{array}{l}\text { Aglutinina de soja } \\
\text { pentasacarídeo }\end{array} \\
\end{array}$ & gi|6729836 & 5.15 & 27555 & 27 & 17 & 6 & 614 \\
\hline & 2 & 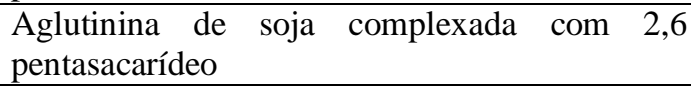 & gi|6729836 & 5.15 & 27555 & 34 & 23 & 7 & 895 \\
\hline \multirow[t]{6}{*}{20} & \multirow[t]{3}{*}{1} & Inibidor de tripsina TIA & gi|354134 & 4.61 & 20310 & 55 & 17 & 10 & 383 \\
\hline & & Inibidor de tripsina Kunitz KTI1 & gi|125722 & 4.97 & 22817 & 29 & 7 & 4 & 216 \\
\hline & & Inibidor de tripsina Kunitz KTI2 & gi 125723 & 6.14 & 23071 & 25 & 5 & 4 & 102 \\
\hline & \multirow[t]{3}{*}{2} & Inibidor de tripsina subtipo A & gi| 18770 & 4.99 & 24346 & 27 & 20 & 7 & 585 \\
\hline & & Inibidor de tripsina Kunitz KTI1 & gi|125722 & 4.97 & 22817 & 11 & 3 & 2 & 149 \\
\hline & & Produto de proteína sem nome (Soja) & gi 18536 & 5.07 & 70535 & 4 & 10 & 2 & 229 \\
\hline \multirow[t]{2}{*}{22} & 1 & Produto de proteína sem nome (Soja) & gi|18536 & 5.07 & 70535 & 4 & 10 & 2 & 229 \\
\hline & 2 & Lipoxigenase & gi|1794172 & 6.12 & 97137 & 5 & 5 & 4 & 55 \\
\hline \multirow[t]{5}{*}{25} & \multirow[t]{3}{*}{1} & Proteína de ligação de glicose & gi|170064 & 6.42 & 60884 & 46 & 47 & 20 & 939 \\
\hline & & Proteína de ligação da sacarose 2 & gi|29469054 & 6.12 & 56082 & 17 & 17 & 8 & 418 \\
\hline & & Proteína de ligação da sacarose - homóloga S-64 & gi|6179947 & 6.32 & 56142 & 12 & 16 & 8 & 348 \\
\hline & \multirow[t]{2}{*}{2} & Proteína de ligação de glicose & gi| 170064 & 6.42 & 60884 & 44 & 59 & 21 & 1106 \\
\hline & & Proteína de ligação da sacarose 2 & gi|29469054 & 6.12 & 56082 & 19 & 24 & 9 & 417 \\
\hline
\end{tabular}




\section{CONCLUSÕES}

A partir dos resultados observados e expostos anteriormente, para as análises proteômicas entre as variedades de soja convencionais genitoras, geneticamente modificadas para tolerância ao herbicida glifosato e orgânicas, podemos concluir que:

- Os mapas protéicos das amostras de soja convencionais e as GMs foram considerados semelhantes com porcentagens de matching superiores a $70 \%$, enquanto nas amostras de soja orgânicas com índices menores se diferenciam das demais.

- As variabilidades encontradas entre as três amostras convencionais e entre as amostras dos grupos convencionais versus orgânicas foram maiores que a comparação das amostras GMs com suas genitoras correspondentes.

- Nas imagens dos géis 2D, foram identificados e quantificados os spots correspondentes às proteínas isoladas, sem apresentarem diferenças estatísticas ao nível de significância de 5\% entre os diferentes tipos de cultivo.

- Os principais grupos protéicos da soja, como as frações e subunidades de $\beta$-conglicinina e de glicinina e fatores antinutricionais foram reconhecidos em todas amostra analisadas por espectrometria de massas, enquanto a lipoxigenase foi detectada em apenas uma amostra de soja orgânica.

- Não foi possível identificar alterações de expressão dos peptídeos identificados e analisados.

- A pequena variabilidade encontrada entre as amostras de soja podem ser atribuídas à técnica proteômica e a variabilidade natural das plantas, não comprometendo a inocuidade desses novos alimentos geneticamente modificados. 


\section{REFERÊNCIAS BIBLIOGRÁFICAS}

AHSAN, N.; KOMATSU, S. Comparative analyses of the proteomes of leaves and flowers at various stages of development reveal organ-specific functional differentiation of proteins in soybean. Proteomics, v. 9, n. 21, p. 4889-4907, Nov 2009.

AL-TAWAHA, A. M. et al. Irrigation level affects isoflavone concentrations of early maturing soya bean cultivars. Journal of Agronomy and Crop Science, v. 193, n. 4, p. 238246, Aug 2007.

ALBO, A. G. et al. Proteomic analysis of a genetically modified maize flour carrying Cry1 Ab gene and comparison to the corresponding wild-type. Maydica, v. 52, n. 4, p. 443-455, 2007.

ALEZANDRO, M. R. et al . Soja transgênica BRS 243 RR: determinação de macronutrientes e das isoflavonas daidzeína e genisteína por Cromatografia Líquida de Alta Eficiência (CLAE). Ciência e Tecnologia de Alimentos, Campinas, v. 28, n. 3, Sept. 2008.

AMARANTE, J. O. P. et al . Glifosato: propriedades, toxicidade, usos e legislação. Química Nova, São Paulo, v. 25, n. 4, July 2002.

ANDERSON, N. L.; MATHESON, A. D.; STEINER, S. Proteomics: applications in basic and applied biology. Current Opinion in Biotechnology, v. 11, p. 408-412, 2000.

ANVISA, 2002. Agência Nacional de Vigilância Sanitária. Resolução n. 2 de 07 de janeiro de 2002. Alimentos com Alegações de Propriedades Funcionais e ou de Saúde, Novos Alimentos/Ingredientes, Substâncias Bioativas e Probióticos. Disponível em: "http://www.anvisa.gov.br/alimentos/comissoes/tecno_lista_alega.htm". Acesso em: 20 de janeiro de 2011.

ANKLAM, E. et al. Analytical methods for detection and determination of genetically modified organisms in agricultural crops and plant-derived food products. European Food Research and Technology, v. 214, n. 1, p. 3-26, Jan 2002.

ARBOS, K. A . et al. Atividade antioxidante e teor de fenólicos totais em hortaliças orgânicas e convencionais. Ciência e Tecnologia de Alimentos, v. 30, n.2, p. 501-506, 2010.

ARBOS, K. A . et al. Segurança alimentar de hortaliças orgânicas: aspectos sanitários e nutricionais. Ciência e Tecnologia de Alimentos, v. 30, p. 215-220, 2010.

ASSUPÇÃO, L. C. Diversidade da comunidade bacteriana endofítica de sementes de soja e o seu potencial biotecnológico. Piracicaba, 2008. 93p. Dissertação (mestrado). Escola Superior de Agricultura Luiz de Queiroz, 2008. 
AVILA, M.R. et al. Componentes do rendimento, teores de isoflavonas, proteínas, óleo e qualidade de sementes de soja. Revista brasileira de sementes, v. 29, n. 3, 2007.

AXELROD, B. CHEESBROUGH, T. M., LAAKSO, S. Lipoxygenases in soybean. Methods Enzymology, v. 71, p. 441-451, 1981.

AZADI, H.; HO, P. Genetically modified and organic crops in developing countries: A review of options for food security. Biotechnology Advances, v. 28, n. 1, p. 160-168, JanFeb 2010.

BANDOW, J. E. et al. Improved image analysis workflow for 2-D gels enables large-scale 2D gel-based proteomics studies - COPD biomarker discovery study. Proteomics, v. 8, n. 15, p. 3030-3041, Aug 2008.

BARROS, J. G. A. et al. Efeito do inibidor de protease Kunitz sobre níveis de lipoxigenases em sementes de soja. Ciência e Agrotecnologia, v. 32, n. 4, Aug. 2008.

BATISTA, R. et al. A proteomic study to identify soya allergens - The human response to transgenic versus non-transgenic soya samples. International Archives of Allergy and Immunology, v. 144, n. 1, p. 29-38, 2007.

BERTH, M. et al. The state of the art in the analysis of two-dimensional gel electrophoresis images. Applied Microbiology and Biotechnology, v. 76, n. 6, p. 1223-1243, Oct 2007.

BRANDAO, A. R.; BARBOSA, H. S.; ARRUDA, M. A. Z. Image analysis of twodimensional gel electrophoresis for comparative proteomics of transgenic and non-transgenic soybean seeds. Journal of Proteomics, v. 73, n. 8, p. 1433-1440, Jun 2010.

BRASIL. Ministério da Agricultura, Pecuária e Abastecimento. Portaria $n^{0} 262$ de 23.11.1983, D.O.U. 25.11.1983, Brasília/DF.

CAMARA, M. C. C et al . A produção acadêmica sobre a rotulagem de alimentos no Brasil. Revista Panamericana de Salud Pública, v. 23, n. 1, Jan. 2008.

CARDOSO, L. R. et al. Atividade de inibidores de proteases em linhagens de soja geneticamente melhoradas. Alimentos e Nutrição, v.18, n.1, p. 19-26, Mar. 2007.

CAREY, L.; MITNIK, L. Trends in DNA forensic analysis. Electrophoresis, v. 23, n. 10, p. 1386-1397, May 2002.

CARRAO-PANIZZI, M. C et al . Genetic variation and environmental effects on betaconglycinin and glycinin content in Brazilian soybean cultivars. Pesquisa Agropecuária Brasileira, v. 43, n. 9, Sept. 2008. 
CASTRO, V. A. O. T. Análise comparativa de mapas protéicos de amostras de soja convencional e tolerantes ao herbicida glifosato visando à inocuidade alimentar. São Paulo, 2009, 104p. Tese de doutorado - Faculdade de Ciências Farmacêuticas, Universidade de São Paulo, São Paulo, 2009.

CELEC, P. et al. Biological and biomedical aspects of genetically modified food. Biomedicine \& Pharmacotherapy, v. 59, n. 10, p. 531-540, 2005.

COCKBURN, A. Assuring the safety of genetically modified (GM) foods: the importance of an holistic, integrative approach. Journal of Biotechnology, v. 98, n. 1, p. 79-106, Sep 2002.

CONCEICAO, F. R.; MOREIRA, A. N.; BINSFELD, P. C.. Detecção e quantificação de organismos geneticamente modificados em alimentos e ingredientes alimentares. Ciência Rural, v. 36, n. 1, 2006.

CORPILLO, D. et al. Proteomics as a tool to improve investigation of substantial equivalence in genetically modified organisms: The case of a virus-resistant tomato. Proteomics, v. 4, n. 1, p. 193-200, Jan 2004.

CROUSE, J. R. et al. A randomized trial comparing the effect of casein with that of soy protein containing varying amounts of isoflavones on plasma concentrations of lipids and lipoproteins. Archives of Internal Medicine, v. 159, n. 17, p. 2070-2076, Sep 1999.

CTNBio. Informações gerais. Ministério de Ciência e Tecnologia. Disponível em: "http://www.ctnbio.gov.br". Acesso em fevereiro de 2011.

DANGOUR, A. D. et al. Nutritional quality of organic foods: a systematic review. American Journal of Clinical Nutrition, v. 90, n. 3, p. 680-685, Sep 2009.

DILL, G. M.; CAJACOB, C. A.; PADGETTE, S. R. Glyphosate-resistant crops: adoption, use and future considerations. Pest Management Science, v. 64, n. 4, p. 326-331, Apr 2008.

DIXIT, A. K. et al. Effect of gamma irradiation on lipoxygenases, trypsin inhibitor, raffinose family oligosaccharides and nutritional factors of different seed coat colored soybean (Glycine max L.). Radiation Physics and Chemistry, v. 80, n. 4, p. 597-603, Apr 2011.

DUMAS, M.E.; CANLET, C.; DEBRAUWER, L.; MARTIN, P.; PARIS, A. Selection of biomarkers by a multivariate statistical processing of composite metabonomic data sets using multiple. Journal of Proteome Research. v. 4, n. 5, p. 1485-92, 2005.

EMBRAPA SOJA. Empresa Brasileira de Pesquisas Agropecuária. Dados econômicos: Soja em números (Safra 2008/2009). Disponível em: "http://www.cnpso.embrapa.br/index.php?. Acesso em: 18 de janeiro de 2011. 
ESTEVES, E. A.; MONTEIRO, J. B. R. Efeitos benéficos das isoflavonas de soja em doenças crônicas. Revista de Nutrição, v. 14, n. 1, p. 43-52, 2001.

ERAVCI, M. et al. Improved comparative proteome analysis based on two-dimensional gel electrophoresis. Proteomics, v. 7, n. 4, p. 513-523, Feb 2007.

ETZLER, M. E. Plant-lectins - molecular and biological aspects. Annual Review of Plant Physiology and Plant Molecular Biology, v. 36, p. 209-234, 1985.

FANTE, C. A. et al. Respostas fisiológicas em cultivares de soja submetidas ao alagamento em diferentes estádios. Bragantia. 2010, vol.69, n.2, p. 253-261, 2011.

FDA. U.S. Food and Drug Administration. Food labeling: Health claim; soy protein and coronary heart disease. October 26, 1999. Disponível em: http://www.fda.gov/. Acesso em março de 2011.

FRANKEL, E.N. Lipid oxidation. 2.ed. Bridgwater: Oily Press, P.391-405, 2005.

FRIEDMAN, M.; BRANDON, D. L. Nutritional and health benefits of soy proteins. Journal of Agricultural and Food Chemistry, v. 49, n. 3, p. 1069-1086, Mar 2001.

FRIEDMAN, M. et al. Comparison of a commercial soybean cultivar and an isoline lacking the kunitz trypsin-inhibitor - composition, nutritional-value, and effects of heating. Journal of Agricultural and Food Chemistry, v. 39, n. 2, p. 327-335, Feb 1991.

FUKUDA, T. et al. Molecular analysis and physicochemical properties of electrophoretic variants of wild soybean Glycine soja storage proteins. Journal of Agricultural and Food Chemistry, v. 53, n. 9, p. 3658-3665, May 2005.

GALDOS-RIVEROS et al. Proteômica: novas fronteiras na pesquisa clínica enciclopédia biosfera. Centro Científico Conhecer, v. 6, n. 11, 2010.

GARCIA-VILLALBA, R. et al. Comparative metabolomic study of transgenic versus conventional soybean using capillary electrophoresis-time-of-flight mass spectrometry. Journal of Chromatography, v. 1195, n. 1-2, p. 164-173, Jun 2008.

GASO-SOKAC, D.; KOVAC, S.; JOSIC, D. Application of Proteomics in Food Technology and Food Biotechnology: Process Development, Quality Control and Product Safety. Food Technology and Biotechnology, v. 48, n. 3, p. 284-295, Jul-Sep 2010.

GE HEALTHCARE. Manual do usuário, 11-0034-38, Image master 2Dplatinum 6.0, Edition AA, 2005.

GENOVESE, M.I.; LAJOLO, F.M.. Determinação de isoflavonas em derivados de soja. Ciências e Tecnologia de Alimentos, v. 21, n. 1, Jan. 2001. 
GENOVESE, M.I. et al . Avaliação do teor de isoflavonas de "suplementos nutricionais à base de soja". Revista Brasileira de Ciências Farmacêuticas, v. 39, n. 2, 2003.

GENOVESE, M. I. HASSIMOTTO, N. M. A.; LAJOLO, F. M. Isoflavone profile and antioxidant activity of Brazilian soybean varieties. Food Science and Technology International, v. 11, n. 3, p. 205-211, 2005.

GEORGE, M. A. et al. Identification of low lectin mutants in soybean. Plant Breeding, v. 127, n. 2, p. 150-153, Apr 2008.

GIORA, C. B. Avaliação de equivalência substancial e potencial de alergenicidade de cultivares de soja tolerantes ao herbicida glifosato. São Paulo, 2009, 139p. Tese de doutorado - Faculdade de Ciências Farmacêuticas, Universidade de São Paulo, São Paulo, 2009.

GORG, A.; WEISS, W.; DUNN, M. J. Current two-dimensional electrophoresis technology for proteomics. Proteomics, v. 4, n. 12, p. 3665-3685, Dec 2004.

HERMAN, E. M. et al. Genetic modification removes an immunodominant allergen from soybean. Plant Physiology, v. 132, n. 1, p. 36-43, May 2003.

AHILL, J. E.; BREIDENB.RW. Proteins of soybean seeds. 1. Isolation and characterization of major components. Plant Physiology, v. 53, n. 5, p. 742-746, 1974.

BHILL, J. E.; BREIDENB.RW. Proteins of soybean seeds. 2. Accumulation of major protein components during seed development and maturation. Plant Physiology, v. 53, n. 5, p. 747$751,1974$.

HOEFKENS, C. et al. Consuming organic versus conventional vegetables: The effect on nutrient and contaminant intakes. Food and Chemical Toxicology, v. 48, n. 11, p. 30583066, Nov 2010.

HOLT, J. S.; POWLES, S. B.; HOLTUM, J. A. M. Mechanisms and agronomic aspects of herbicide resistance. Annual Review of Plant Physiology and Plant Molecular Biology, v. 44, p. 203-229, 1993.

HUNGERFORD, J. M. Committee on natural toxins and food allergens. Journal of Aoac International, v. 87, n. 1, p. 270-275, Jan-Feb 2004.

IASSONOVA, D. R. et al. Evidence of an Enzymatic Source of Off Flavors in "Lipoxygenase-Null" Soybeans. Journal of the American Oil Chemists Society, v. 86, n. 1, p. 59-64, Jan 2009.

IWASAKI, M.; TSUGANE, S. Risk factors for breast cancer: epidemiological evidence from Japanese studies. Cancer Science, v. 102, n. 9, p. 1607-1614, Sep 2011. 
JAMES, C. Global Status of Commercialized Biotech/GM Crop: 2009. ISAAA Brief 41. Executive Summary, 2009.

JAMES, C. Global Status of Commercialized Biotech/GM Crop: 2010. ISAAA Brief 42. Executive Summary, 2010.

JAMES, P. Protein identification in the post-genome era: the rapid rise of proteomics. Quarterly Reviews of Biophysics, v. 30, n. 4, p. 279-331, Nov 1997.

JOU, H. J.; LING, P. Y.; WU, S. C. Comparison of $70 \mathrm{mg}$ and $35 \mathrm{mg}$ isoflavone soya supplement for menopause symptoms. International Journal of Gynecology \& Obstetrics, v. 90, n. 2, p. 159-160, Aug 2005.

KALINSKI, A. et al. A soybean vacuolar protein (P34) related to thiol proteases is synthesized as a glycoprotein precursor during seed maturation. Journal of Biological Chemistry, v. 267, n. 17, p. 12068-12076, Jun 1992.

KLETER, G. A.; PEIJNENBURG, A. Presence of potential allergy-related linear epitopes in novel proteins from conventional crops and the implication for the safety assessment of these crops with respect to the current testing of genetically modified crops. Plant Biotechnology Journal, v. 1, n. 5, p. 371-380, Sep 2003.

KITAMURA, K. et al Genetic analysis of a null-allele for lipoxygenase-3 in soybean seed. Crop Science, v. 23, p. 924-927, 1983.

KLOSE, J. Protein mapping by combined isoeletric focusing and eletrophoresis of mouse tissues. A novel approach to testing for induced point mutations in mammals. Humangenetik, v. 26, p. 231-243, 1975.

KOBAYASHI, H. et al. A soybean Kunitz trypsin inhibitor suppresses ovarian cancer cell invasion by blocking urokinase upregulation. Clinical \& Experimental Metastasis, v. 21, n. 2, p. 159-166, 2004.

KOK, E. J.; KUIPER, H. A. Comparative safety assessment for biotech crops. Trends in Biotechnology, v. 21, n. 10, p. 439-444, Oct 2003.

KOLLER, A. et al. Proteomic survey of metabolic pathways in rice. Proceedings of the National Academy of Sciences of the United States of America, v. 99, n. 18, p. 1196911974, Sep 2002.

KOMATSU, S.; AHSAN, N. Soybean proteomics and its application to functional analysis. Journal of Proteomics, v. 72, n. 3, p. 325-336, Apr 2009.

KONIG, A. et al. Assessment of the safety of foods derived from genetically modified (GM) crops. Food and Chemical Toxicology, v. 42, n. 7, p. 1047-1088, Jul 2004. 
KRISHNAN, H. B.; KIM, W. S. A four-nucleotide base-pair deletion in the coding region of the Bowman-Birk protease inhibitor gene prevents its accumulation in the seeds of Glycine microphylla P1440956. Planta, v. 217, n. 3, p. 523-527, Jul 2003.

KRISHNAN, H. B. et al. Identification of glycinin and beta-conglycinin subunits that contribute to the increased protein content of high-protein soybean lines. Journal of Agricultural and Food Chemistry, v. 55, n. 5, p. 1839-1845, Mar 2007.

KUHNLE, G. G. C. et al. Phytoestrogen content of fruits and vegetables commonly consumed in the UK based on LC-MS and C-13-labelled standards. Food Chemistry, v. 116, n. 2, p. 542-554, Sep 2009.

KUIPER, H. A. et al. Substantial equivalence - an appropriate paradigm for the safety assessment of genetically modified foods? Toxicology, v. 181, p. 427-431, Dec 2002.

LAJOLO, F. M.; GENOVESE, M. I. Nutritional significance of lectins and enzyme inhibitors from legumes. Journal of Agricultural and Food Chemistry, v. 50, p. 6592-6598, 2002.

LAJOLO, F. M.; NUTTI, M. R. Transgênicos: bases científicas da sua segurança. SBAN. São Paulo, 2003.

LAEMMLI, U. K. Cleavage of structural proteins during the assembly of the head of bacteriophage T4. Nature, v. 227, n. 259, p. 680-685, 1970.

LAMETSCH, R., BENDIXEN, E. Proteome analysis applied to meat science: Characterizing post mortem changes in porcine muscle, Journal of Agricultural and Food Chemistry, v. 49, p. 4531-4537, 2001.

L'HOCINE, L.; BOYE, J. I.; JOUVE, S. Ionic strength and $\mathrm{pH}$-induced changes in the immunoreactivity of purified soybean glycinin and its relation to protein molecular structure. Journal of Agricultural and Food Chemistry, v. 55, n. 14, p. 5819-5826, Jul 2007.

LEHESRANTA, S. J. et al. Comparison of tuber proteomes of potato varieties, landraces, and genetically modified lines. Plant Physiology, v. 138, n. 3, p. 1690-1699, Jul 2005.

LIENER, I. E. Possible adverse-effects of soybean anticarcinogens. Journal of Nutrition, v. 125, n. 3, p. S744-S750, Mar 1995.

LIM, C. W. et al. Comparative Proteomic Analysis of Soybean Nodulation Using a Supernodulation Mutant, SS2-2. Bioscience Biotechnology and Biochemistry, v. 74, n. 12, p. 2396-2404, Dec 2010.

LIMA, G. P. P.; VIANELLO, F. Review on the main differences between organic and conventional plant-based foods. International Journal of Food Science and Technology, v. 46, n. 1, p. 1-13, Jan 2011. 
MACHADO, F. P. P. et al. Effects of heating on protein quality of soybean flour devoid of Kunitz inhibitor and lectin. Food Chemistry, v. 107, n. 2, p. 649-655, Mar 2008.

MAGKOS, F.; ARVANITI, F.; ZAMPELAS, A. Putting the safety of organic food into perspective. Nutrition Research Reviews, v. 16, n. 2, p. 211-222, Dec 2003.

MAJOR, I. T.; CONSTABEL, C. P. Functional analysis of the Kunitz trypsin inhibitor family in poplar reveals biochemical diversity and multiplicity in defense against herbivores. Plant Physiology, v. 146, n. 3, p. 888-903, Mar 2008.

MAMONE, G. et al. Analysis of food proteins and peptides by mass spectrometry-based techniques. Journal of Chromatography A, v. 1216, n. 43, p. 7130-7142, Oct 2009.

MANN, M.; HENDRICKSON, R. C.; PANDEY,A. Analysis of proteins and proteomes by mass spectrometry. Annual Review of Biochemistry, Palo Alto, v.70, p.437-473, 2001.

MENDOZA, G. D. Complejo enzimático citocromo P450 monooxigenasa en plantas. Agricultura Técnica en México, vol.35, n.2, p. 225-231, 2009.

MEUNIER, B. et al. Data analysis methods for detection of differential protein expression in two-dimensional gel electrophoresis. Analytical Biochemistry, v. 340, n. 2, p. 226-230, May 2005.

MOLDES, C. A. et al. Biochemical responses of glyphosate resistant and susceptible soybean plants exposed to glyphosate. Acta Physiologiae Plantarum, v. 30, n. 4, p. 469-479, Jul 2008.

MONTEIRO, M.R.P. et al . Qualidade protéica de linhagens de soja com ausência do Inibidor de Tripsina Kunitz e das isoenzimas Lipoxigenases. Revista de Nutrição, v. 17, n. 2, jun. 2004.

MORAES, R.M.A et al. Caracterização bioquímica de linhagens de soja com alto teor de proteína. Pesquisa Agropecuária Brasileira, v. 41, n. 5, May 2006.

NATALE, M. et al. Cow's milk allergens identification by two-dimensional immunoblotting and mass spectrometry. Molecular Nutrition \& Food Research, v. 48, n. 5, p. 363-369, Oct 2004.

${ }^{A}$ NATARAJAN, S. et al. Proteomic and genetic analysis of glycinin subunits of sixteen soybean genotypes. Plant Physiology and Biochemistry, v. 45, n. 6-7, p. 436-444, Jun-Jul 2007.

NATARAJAN, S. et al. Comparison of protein solubilization methods suitable for proteomic analysis of soybean seed proteins. Analytical Biochemistry, v. 342, n. 2, p. 214-220, Jul 2005. 
${ }^{B}$ NATARAJAN, S.S. et al. Determination of optimal protein quantity required to identify abundant and less abundant soybean seed proteins by 2D-PAGE and MS. Plant Molecular Biology Reporter, v. 25, n. 1-2, p. 55-62, Jun 2007.

NATARAJAN, S.S. Characterization of storage proteins in wild (Glycine soja) and cultivated (Glycine max) soybean seeds using proteomic analysis. Journal of Agricultural and Food Chemistry, v. 54, n. 8, p. 3114-3120, Apr 2006.

NEPOMUCENO, A.L. Transgênicos: próximas ondas. DISPONÍVEL EM: "http://www.cnpso.embrapa.br/download/artigos/proxonda.pdf". Acesso em: 07/02/2011.

NOZU, Y.; TSUGITA, A.; KAMIJO, K. Proteomic analysis of rice leaf, stem and root tissues during growth course. Proteomics, v. 6, n. 12, p. 3665-3670, Jun 2006.

O'FARELL, P. H., High resolution two-dimensional electrophoresis of proteins. Journal of Biological Chemistry. v. 250, p. 4007-4021, 1975.

OLIVEIRA, D.A. et al . Lipoxigenases e teor de ácido linolênico relacionados à qualidade de sementes de soja. Revista brasileira de sementes, v. 28, n. 1, Apr. 2006.

ORMOND, J.G.P. et al. Agricultura orgânica: quando o passado é futuro. Rio de Janeiro: BNDES Setorial, 2002. 24p.

OVERVOORDE, J. P., FROMMER, W. B., GRIMES, H. D. A soybean sucrose binding protein independetly mediates nonsaturable sucrose uptake in yeast. The Plant Cell, v. 8, p. 271-280, 1996.

PADGETTE, S. R. et al. Development, identification, and characterization of a glyphosatetolerant soybean line. Crop Science, v. 35, n. 5, p. 1451-1461, Sep-Oct 1995.

PADOVAN, M. P. et al. Avaliação de cultivares de soja, sob manejo orgânico, para fins de adubação verde e produção de grãos. Pesquisa Agropecuária Brasileira. 2002, vol. 37, n. 12, p. 1705-1710, 2002.

PIÑEIRO, C. et al. Proteomics as a tool for the investigation of seafood and other marine products, J. Proteome Res. 2 (2003) 127-135.

PRIGGE, S.T et al. Structure and mechanisms of lipoxygenases. Biochimie, v.79, p.629-636, 1997.

RAMOS, S. Effects of dietary flavonoids on apoptotic pathways related to cancer chemoprevention. Journal of Nutritional Biochemistry, v. 18, n. 7, p. 427-442, Jul 2007. 
REDDY, K. N.; ZABLOTOWICZ, R. M. Glyphosate-resistant soybean response to various salts of glyphosate and glyphosate accumulation in soybean nodules. Weed Science, v. 51, n. 4, p. 496-502, Jul-Aug 2003.

REYNOLDS, K. et al. A meta-analysis of the effect of soy protein supplementation on serum lipids. American Journal of Cardiology, v. 98, n. 5, p. 633-640, Sep 2006.

RICKERT, K. W.; KLINMAN, J. P. Nature of hydrogen transfer in soybean lipoxygenase 1: Separation of primary and secondary isotope effects. Biochemistry, v. 38, n. 38, p. 1221812228, Sep 1999.

RICROCH, A. E.; BERGE, J. B.; KUNTZ, M. Evaluation of Genetically Engineered Crops Using Transcriptomic, Proteomic, and Metabolomic Profiling Techniques. Plant Physiology, v. 155, n. 4, p. 1752-1761, Apr 2011.

RUEBELT, M. C. et al. Application of two-dimensional gel electrophoresis to interrogate alterations in the proteome of genetically modified crops. 1. Assessing analytical validation. Journal of Agricultural and Food Chemistry, v. 54, n. 6, p. 2154-2161, Mar 2006.

SAMARAH, N. H. et al. Dehydrin-like proteins in soybean seeds in response to drought stress during seed filling. Crop Science, v. 46, n. 5, p. 2141-2150, Sep-Oct 2006.

SANTOS, G. C., MONTEIRO, M. Sistema orgânico de produção de alimentos. Alimentos e Nutrição, v. 15, n. 1, 2004.

SATHE, S.K.; KSHIRSAGAR, H.H.; KENNETH, H.R. Advances in seed protein research: a perspective on seed allergens, Journal of food science, v. 70, n.6, p.93-120, 2005.

SATOH, R. et al. Proteomic analysis of known and candidate rice allergens between nontransgenic and transgenic plants. Regulatory Toxicology and Pharmacology, v. 59, n. 3, p. 437-444, Apr 2011.

SEWEKOW, E. et al. Isolation of soybean protein P34 from oil bodies using hydrophobic interaction chromatography. Bmc Biotechnology, v. 8, Mar 2008.

SHAW, J.; ROWLINSON, R.; NICKSON, J.; STONE, T.; SWEET, A.; WILLIAMS, K.; TONGE, R. Evaluation of saturation labelling two-dimensional difference gel electrophoresis fluorescent dyes. Proteomics, 2003, 3, 1181-1195.

SHEVCHENKO, A. et al. Mass spectrometric sequencing of proteins from silver stained polyacrylamide gels. Analytical Chemistry, v. 68, n. 5, p. 850-858, Mar 1996.

SHEWRY, P. R.; NAPIER, J. A.; TATHAM, A. S. Seed storage proteins - structures and biosynthesis. Plant Cell, v. 7, n. 7, p. 945-956, Jul 1995. 
SIEDOW, J. N. PLANT LIPOXYGENASE - STRUCTURE AND FUNCTION. Annual Review of Plant Physiology and Plant Molecular Biology, v. 42, p. 145-188, 1991.

SILVA, M. R.; SILVA, M. A .A. P. Fatores antinutricionais: inibidores de proteases e lectinas. Revista de Nutrição, v. 13, n. 1, Apr. 2000.

SILVA, P.A. Estudo da qualidade fisiológica, bioquímica e ultra-estrutural, durante o desenvolvimento e a secagem de sementes de soja. Lavras, 2006, 55p. Tese de doutorado Universidade Federal de Lavras, Lavras, 2006.

SIRTORI, C. R.; EBERINI, I.; ARNOLDI, A. Hypocholesterolaemic effects of soya proteins: results of recent studies are predictable from the Anderson meta-analysis data. British Journal of Nutrition, v. 97, n. 5, p. 816-822, May 2007.

SRIYAM, S., SINCHAIKUL, S., TANTIPAIBOONWONG, P., TZAO, C., PHUTRAKUL, S., CHENA, S. Enhanced detectability in proteome studies. Journal of Chromatography, 849, p. 91-104, 2007.

STASWICK, P. E.; HERMODSON, M. A.; NIELSEN, N. C. The amino-acid-sequence of the a2b1a subunit of glycinin. Journal of Biological Chemistry, v. 259, n. 21, p. 3424-3430, 1984.

STEPHENSON, J. Public health experts take aim at a moving target: food borne infections. Journal of the American Medical Association, v. 277, n. 2, p. 97-98, 1997.

STESSL, M.; NOE, C. R.; LACHMANN, B. Influence of image-analysis software on quantitation of two-dimensional gel electrophoresis data. Electrophoresis, v. 30, n. 2, p. 325328, Jan 2009.

SUSSULINI, A. Avaliação das alterações protéicas e metaloprotéicas em soja após o processamento de modificação genética. Campinas, 2007, 72p. Dissertação de mestrado Instituto de Química - Universidade Estadual de Campinas, Campinas, 2007.

SUTHERLAND, L. A. "Effectively organic": Environmental gains on conventional farms through the market? Land Use Policy, v. 28, n. 4, p. 815-824, Oct 2011.

SZLISZKA, E.; KROL, W. Soy isoflavones augment the effect of TRAIL-mediated apoptotic death in prostate cancer cells. Oncology Reports, v. 26, n. 3, p. 533-541, Sep 2011.

TAN, S.; EVANS, R.; SINGH, B. Herbicidal inhibitors of amino acid biosynthesis and herbicide-tolerant crops. Amino Acids, v. 30, n. 2, p. 195-204, Mar 2006.

TAN-WILSON, A. L. et al. Sub classification of soybean Bowman-Birk isoinhibitors. Journal America Oil Chemistry Society, v. 65, n. 9, p. 1475-1478, 1988. 
TESHIMA, R.; NAKAMURA, R.; SATOH, R. 2D-DIGE analysis of rice proteins from different cultivars. Regulatory Toxicology and Pharmacology, v. 58, n. 3, p. S30-S35, Dec 2010.

THANH, V. H.; SHIBASAKI, K. Major proteins of soybean seeds - subunit structure of betaconglycinin. Journal of Agricultural and Food Chemistry, v. 26, n. 3, p. 692-695, 1978.

TREZZI, M. et al. Interação entre insetcida organofosforado e herbicidas inibidores da protox e sua implicação na resistência de Euphorbia heterophylla. Scientia Agraria, v. 10, n. 6, p. 423-428, 2009.

UZOGARA, S. G. The impact of genetic modification of human foods in the 21st century: A review. Biotechnology Advances, v. 18, n. 3, p. 179-206, May 2000.

VALLEDOR, L.; JORRIN, J. Back to the basics: Maximizing the information obtained by quantitative two dimensional gel electrophoresis analyses by an appropriate experimental design and statistical analyses. Journal of Proteomics, v. 74, n. 1, p. 1-18, Jan 2011.

VILJOEN, D. D.; DAJEE, B. K.; BOTHA, G. M. Detection of GMO in food products in South Africa: Implications of GMO labelling. African Journal of Biotechnology, v. 5, n. 2, p. 73-82, Jan 2006.

WACLAWOVSKY, A. J. et al. Evidence for the sucrose-binding protein role in carbohydrate metabolism and transport at early developmental stage. Physiologia Plantarum, v. 128, n. 3, p. 391-404, Nov 2006.

XU, C. P. et al. Separation and identification of soybean leaf proteins by two-dimensional gel electrophoresis and mass spectrometry. Phytochemistry, v. 67, n. 22, p. 2431-2440, Nov 2006.

YE, M. L. et al. Advances in chromatographic techniques and methods in shotgun proteome analysis. Trac-Trends in Analytical Chemistry, v. 26, n. 1, p. 80-84, Jan 2007.

YIRIDOE, E. K.; BONTI-ANKOMAH, S.; MARTIN, R. C. Comparison of consumer perceptions and preference toward organic versus conventionally produced foods: A review and update of the literature. Renewable Agriculture and Food Systems, v. 20, n. 4, p. 193205, Dec 2005.

ZARKADAS, M. et al. Common allergenic foods and their labelling in Canada - A review. Can. J. Allergy Clin. Immunol, v. 4, n. 3, p. 118-141, 1999.

ZARKADAS, C. G. et al. Assessment of the protein quality of fourteen soybean Glycine max (L.) Merr. cultivars using amino acid analysis and two-dimensional electrophoresis. Food Research International, v. 40, n. 1, p. 129-146, 2007. 
ZHEN, Y. et al. Comparative proteome analysis of differentially expressed proteins induced by Al toxicity in soybean. Physiologia Plantarum, v. 131, n. 4, p. 542-554, Dec 2007.

ZOBIOLE, L. H. S. et al. Glyphosate reduces shoot concentrations of mineral nutrients in glyphosate-resistant soybeans. Plant and Soil, v. 328, n. 1-2, p. 57-69, Mar 2010.

ZOLLA, L. et al. Proteomics as a complementary tool for identifying unintended side effects occurring in transgenic maize seeds as a result of genetic modifications. Journal of Proteome Research, v. 7, n. 5, p. 1850-1861, May 2008. 


\begin{abstract}
ANEXOS
Eletroforese bi-dimensional de vagens de soja

É possível reconhecer o perfil protéico da soja e seus principais grupos de proteínas de armazenamento, porém percebemos que a intensidade dos spots é menor do que os spots dos grãos maduros. Além disso, nota-se uma possível expressão parcial de proteínas do grupo das glicininas (em destaque), que se apresentam em proporções distintas em relação às sementes maduras.
\end{abstract}

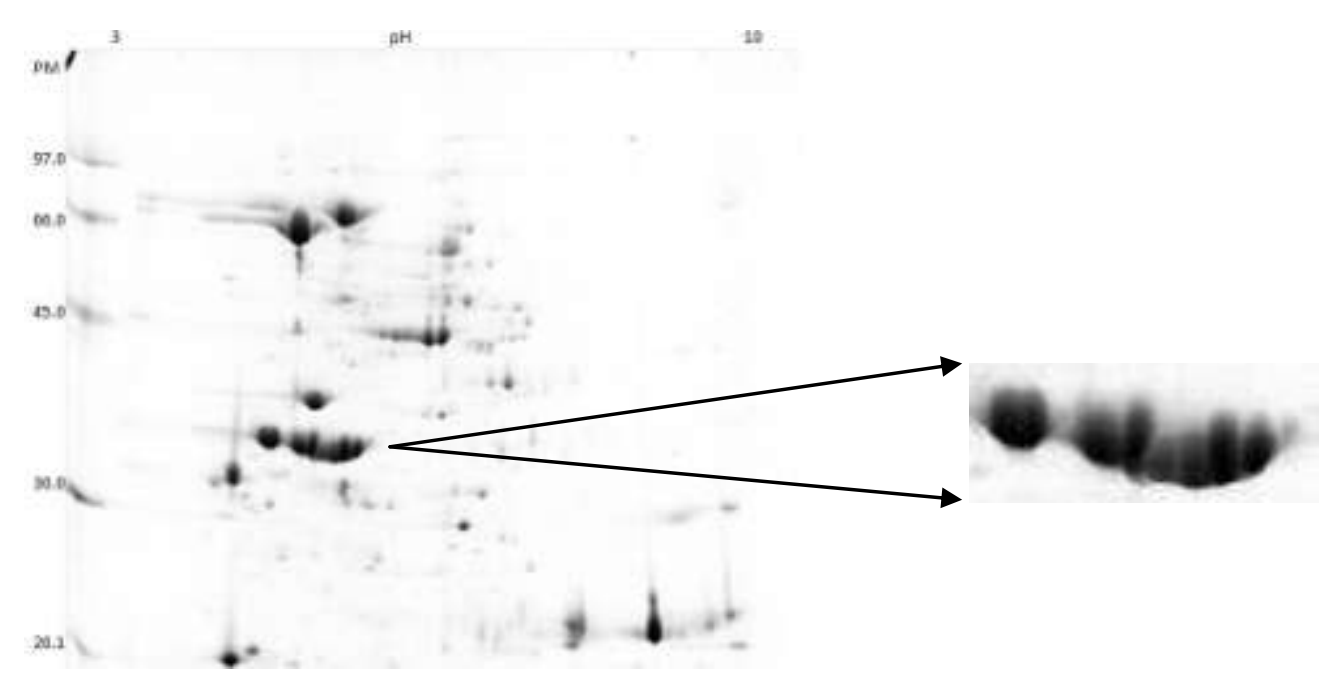

Figura A: Mapa protéico em gel bidimensional com faixa de pH de 3-10, com destaque para a fração ácida de glicinina. Gel preparado com 12\% de acrilamida e corado com Comassie G-250.

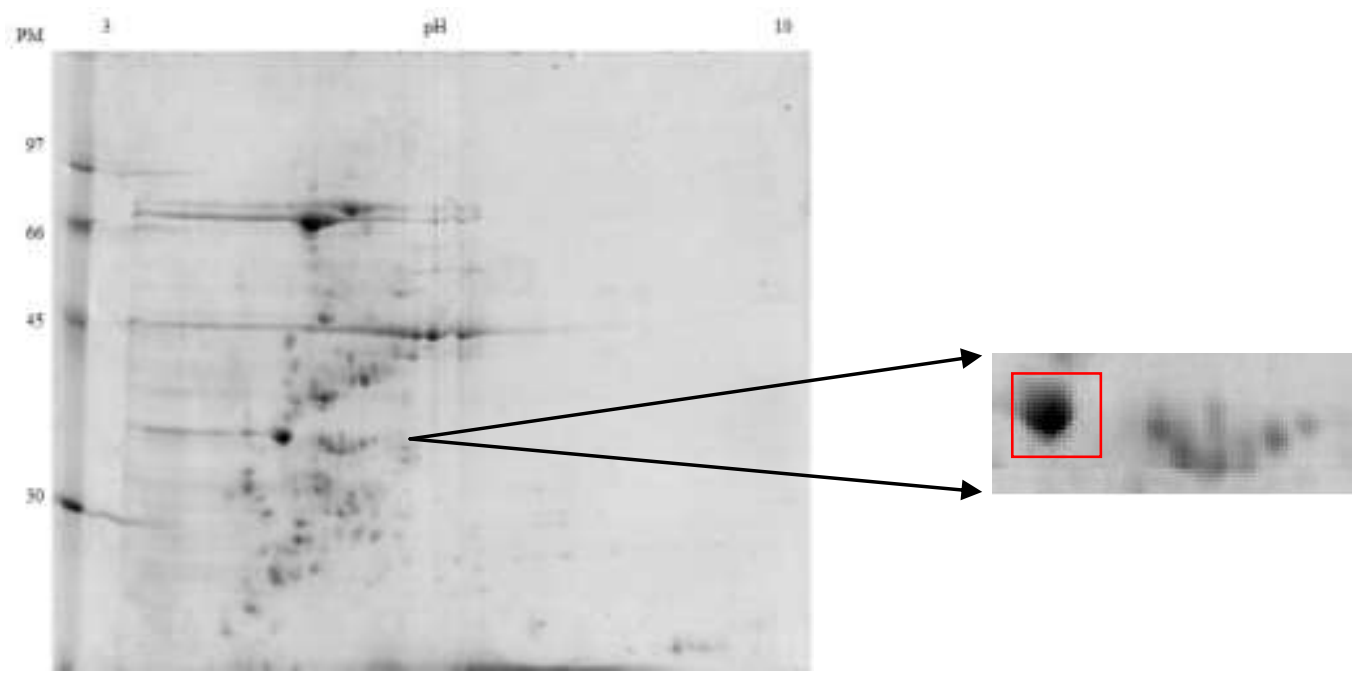

Figura B: Mapa protéico em gel bidimensional com faixa de $\mathrm{pH}$ de 3-10 da vagem de soja, com destaque para a fração ácida de glicinina. Gel preparado com 12\% de acrilamida e corado com Comassie G-250. 